\title{
Correlations of some Neoproterozoic carbonate-dominated successions in South America based on high-resolution chemostratigraphy
} Correlações de algumas sucessões carbonáticas na América do Sul baseado em quimioestratigrafia de alta resolução

\author{
Alcides Nobrega Sial ${ }^{1 *}$, Claudio Gaucher ${ }^{2}$, Aroldo Misi ${ }^{3}$, Paulo Cesar Boggiani ${ }^{4}$, \\ Carlos José Souza de Alvarenga ${ }^{5}$, Valderez Pinto Ferreira ${ }^{1}$, \\ Marcio Martins Pimentel ${ }^{5}$, José Augusto Pedreira ${ }^{6}$, Lucas Verissimo Warren ${ }^{7}$, \\ Rodrigo Fernández-Ramírez ${ }^{8}$, Mauro Geraldes ${ }^{9}$, Natan Silva Pereira ${ }^{1}$, \\ Leticia Chiglino ${ }^{10}$, Wilker dos Santos Cezario ${ }^{1}$
}

\begin{abstract}
This report reviews and incorporates new elemental and isotope chemostratigraphic data for correlation of Neoproterozoic carbonate-dominated successions in South America (Argentina, Bolivia, Brazil, Paraguay and Uruguay). These thick mixed carbonate/siliciclastic successions were largely deposited in epicontinental basins or accumulated on passive margins on the edges of cratons (e.g. São Francisco, Amazonia, Rio Apa Block, Pampia and Río de la Plata paleocontinents) during extensional events related to the rifting of the Rodinia Supercontinent. From the stratigraphic point of view, these successions occur as three mega-sequences: glaciogenic, marine carbonate platform (above glaciomarine diamictites or rift successions), and dominantly continental to transitional siliciclastics. In the orogenic belts surrounding cratons, carbonate-dominated successions with important volcanoclastic/siliciclastic contribution have been, in most cases, strongly deformed. The precise ages of these successions remain a matter of debate, but recently new paleontological and geochronological data have considerably constrained depositional intervals. Here, we report high-resolution $\mathrm{C}, \mathrm{O}, \mathrm{Sr}$, and $\mathrm{S}$ isotope trends measured in well-preserved sample sets and mainly use $\mathrm{Sr}$ and $\mathrm{C}$ isotopes
\end{abstract}

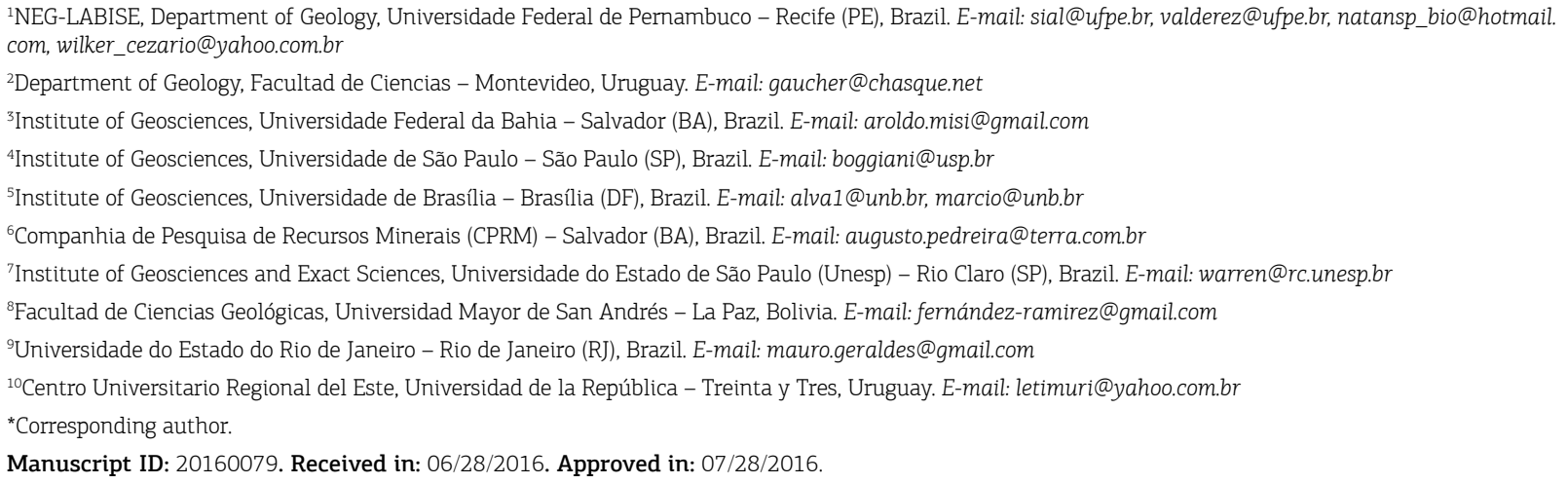


in concert with lithostratigraphic/biostratigraphic observations to provide detailed correlations of these successions. The establishing of a high-level and definite chemostratigraphic correlation between Neoproterozoic basins in South America is the main goal of this work.

KEYWORDS: Carbonate successions; correlation; isotope chemostratigraphy; Neoproterozoic; South America.

\section{INTRODUCTION}

The pioneer C-isotope investigation on Paleoproterozoic carbonate rocks of the Lomagundi province in Africa has evidenced much larger variation of $\delta^{13} \mathrm{C}$ values (Schidlowski et al. 1983) than previously known from Phanerozoic carbonate successions (Veizer et al. 1980). This finding has raised the possibility that the stratigraphic variation of $\delta^{13} \mathrm{C}$ values could potentially be a tool in stratigraphic correlation. Despite widespread effects of late diagenesis on the isotope record, important isotope events could be demonstrated on a global scale by means of isotope chemostratigraphy (e.g. Knoll et al. 1986; Magaritz et al. 1986; Holser 1997, to mention a few) as it became evident that contemporaneous, geographically distant marine strata, registered similar isotopic compositions. Chemostratigraphy serves as one of the principal means of intra- and inter-basinal stratigraphic correlation to assemble the Precambrian stratigraphic record from fragments preserved in scattered successions (Karhu et al. 2010). Definitely, chemostratigraphy became an important tool for providing a timeline that compensates for the poor biostratigraphic resolution of Precambrian fossils (e.g. Veizer et al.1980; Knoll et al. 1986; Magaritz et al. 1986; Knoll \& Walter 1992; Kaufman et al. 1997, 2007; Corsetti \& Kaufman 2003; Halverson et al. 2005; Sial et al. 2015b). Correlations established through chemostratigraphy can be used to comment on climate and biogeochemical changes through time, although the paucity of radiometric constraints on the absolute age of most of extreme isotope excursions leads, sometimes, to debates on their temporal equivalence (e.g. Kaufman et al. 1997; Kennedy et al. 1998; Calver et al. 2004; Allen \& Etienne 2008). In the last three decades, the number of studies relying on isotope chemostratigraphy has grown substantially and, in the case of C-isotope stratigraphy, has been applied to metamorphic rocks up to the high grade (Melezhik et al. 2005; Nascimento et al. 2007; Chiglino et al. 2010; Sial et al. 2015a) and may retain depositional $\delta^{13} \mathrm{C}$ values in even diagenetically altered carbonates (Kaufman et al. 2007).

The first stable isotope laboratory in Brazil was founded in the Center of Nuclear Energy in Agriculture (CENA, University of São Paulo) in 1966. In 1973, the Federal University of Bahia installed a stable isotope laboratory at the Nuclear Geophysics Laboratory of the Research Program vaçóes litostratigráficas/biostratigráficas, para estabelecer correlaçôes detalhadas destas sucessóes. Propor uma correlação quimioestratigráfica entre bacias Neoproterozoicas na América do Sul é o principal objetivo deste trabalho.

PALAVRAS-CHAVE: Sucessão carbonática; correlaçâo; quimioestratigrafia isotópica; Neoproterozoico; América do Sul.

on Geophysics and Geology (PPPG/UFBA) and Petrobras founded another in 1977, at the Center of Research and Development Leopoldo Américo Miguez de Mello (CENPES) in Rio de Janeiro. The widespread use of isotope chemostratigraphy in South America became possible, however, only after the installation of a stable isotope laboratory at the Federal University of Perrnambuco (LABISE) in Recife in 1990 and, later on, in three other Brazilian universities (Brasília, São Paulo, and Pará).

$\mathrm{C}$ - and O-isotope study of Precambrian successions in Brazil was first performed by Torquato \& Misi (1977), who also reported a first cap carbonate characterization (Kaufman et al. 2007). Other pioneer chemostratigraphic investigations in Brazil were performed by Torquato (1980), Zaine (1991), Sial et al. (1992), Chang et al. (1994), Misi \& Kyle (1994), Kawashita (1996), Boggiani et al. (1996), Chang (1997), Santos et al. (2000, 2004), and Sial et al. (2000). Zaine (1991) has measured $\mathrm{C}$ and $\mathrm{O}$ isotope ratios in carbonates of the Tamengo Formation, Corumbá Group, and Boggiani et al. (1996) have identified an upper Ediacaran positive $\delta^{13} \mathrm{C}$ excursion, associated to the occurrence of Cloudina, which was correlated with the Arroyo del Soldado Group in Uruguay (Gaucher 1999). These studies were followed by systematic chemostratigraphic investigations on the Bambui, Una and Araras groups (Misi \& Veizer 1998; Sial et al. 2000; Santos et al. 2000; Nogueira et al. 2003; Alvarenga et al. 2004; Misi et al., 2007). Sial et al. (2000), Bekker et al. (2003), and Maheshwari et al. (2010) confirmed the record of the Lomagundi $\mathrm{C}$ isotope excursion in South America (Iron Quadrangle in Minas Gerais and Paso Severino Formation in Uruguay). Sial et al. (2008) reported, for the first time in South America, the positive carbon isotope excursion (SPICE) from the Steptoean at the Argentine Precordillera and recognized a Sunwaptan negative carbon isotope excursion (SNICE).

An overview on chemostratigraphic correlations of Neoproterozoic carbonate-dominated successions in the South America continent is present here, mainly based on $\mathrm{C}$ - and $\mathrm{O}$-isotope chemostratigraphy, updating a preliminary synthesis published by Misi et al. (2007) and expanding it to encompass some other Neoproterozoic basins in this continent (Uruguay, Argentina, Paraguay, Bolivia, and northeastern Brazil) (Fig. 1). 


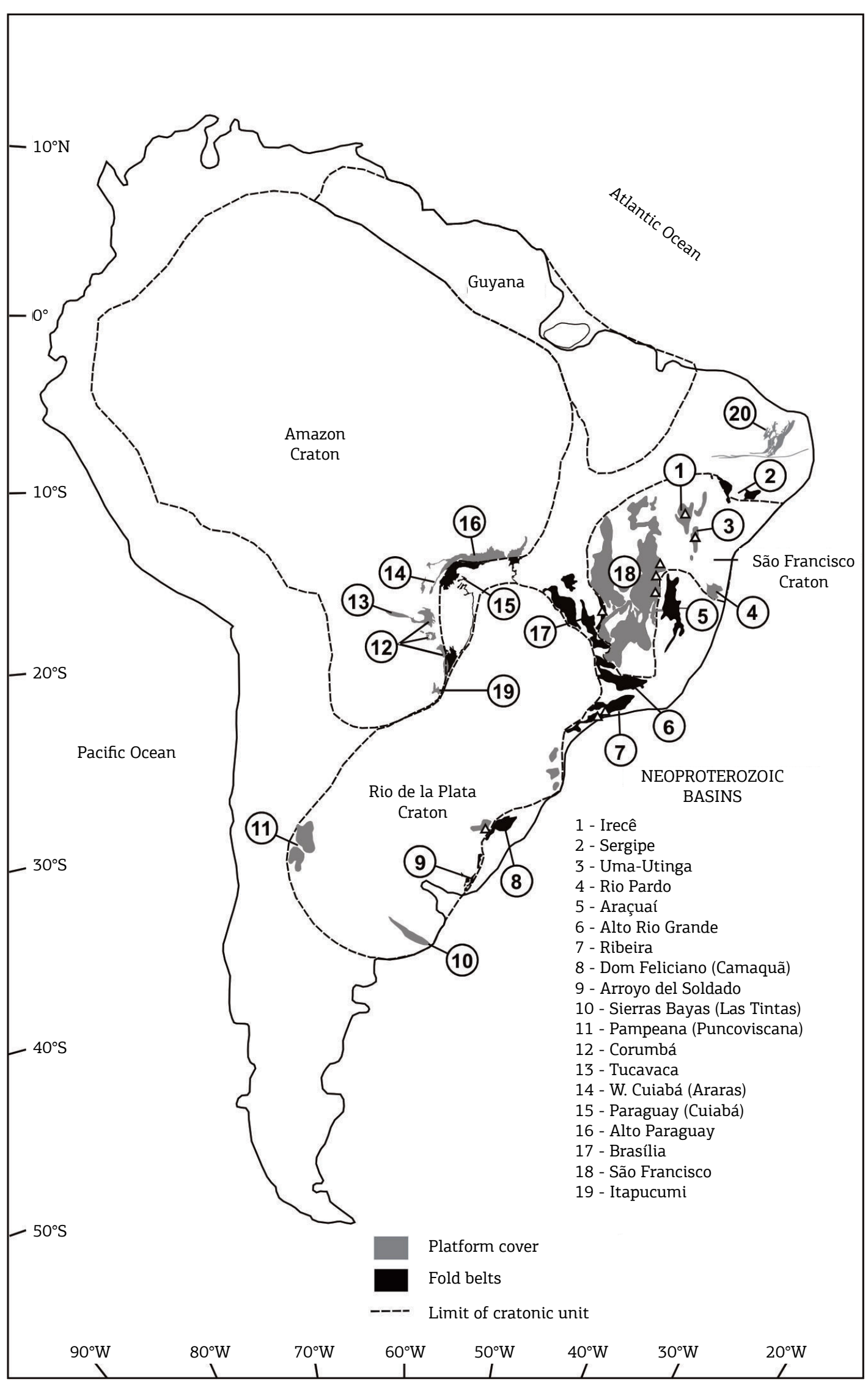

Figure 1. The Neoproterozoic basins of South America (modified from Misi et al. 2007). 


\section{ANALYTICAL METHODS AND SAMPLE EVALUATION}

The majority of the C- and O-isotope analyses plotted here in chemostratigraphic profiles were performed at the Stable Isotope Laboratory (LABISE) of the Federal University of Pernambuco at Recife, although some were also performed at the Universities of Brasília and Sáo Paulo. At the LABISE, $\mathrm{CO}_{2}$ extraction from carbonates was accomplished by the conventional method of sample reaction with orthophosphoric acid, for 12 hours at $25^{\circ} \mathrm{C} \mathrm{(3} \mathrm{days}$ allowed when dolomite was present), followed by cryogenic cleaning and then by spectrometric analyses in a SIRA II or Delta V Advantage mass spectrometers. Analyses at the University of Brasília or University of São Paulo were performed using the Gas Bench on line with Thermofinnigan Delta V Advantage mass spectrometer. For some stratigraphic sections, strontium isotope ratios were analyzed after concentration by ion exchange chromatography and ${ }^{87} \mathrm{Sr} /{ }^{86} \mathrm{Sr}$ values determined in static mode using a Finnigan MAT 262 seven-collector mass spectrometer at the University of Brasília, or University of São Paulo, as well as other laboratories outside South America.
In evaluation of sample quality, it seems that the most effective parameter is the $\mathrm{Mn} / \mathrm{Sr}$ ratio, because $\mathrm{Sr}$ is preferentially removed during recrystallization of metastable carbonate phases, while Mn becomes enriched during formation of late-stage ferroan calcite cement (Ripperdan et al. 1992; Derry et al. 1992; Kaufman et al. 1993; Knoll et al. 1995; Jacobsen \& Kaufman 1999). Although Kaufman \& Knoll (1995) stated that limestones or dolostones with $\mathrm{Mn} / \mathrm{Sr}<10$ commonly retain near primary $\delta^{13} \mathrm{C}$ abundances, limestones were here considered to be unaltered only when $\mathrm{Mn} / \mathrm{Sr}<1.5$ and $\delta^{18} \mathrm{O}$ $>-10 \%$ (VPDB) according to Fölling \& Frimmel (2002) criteria. However, each succession should be evaluated separately to assess the nature of isotopic signals, especially for $\mathrm{Sr}$ isotopes.

\section{AMAZONIA PALEOCONTINENT}

\section{Northern Paraguay Belt}

After the end-Cryogenian glaciation, the central region of Brazil was the site of extensive deposition of platformal carbonates of the 1,300-m-thick Araras Group (Fig. 2). This group includes four formations, a basal cap dolostone (Mirassol

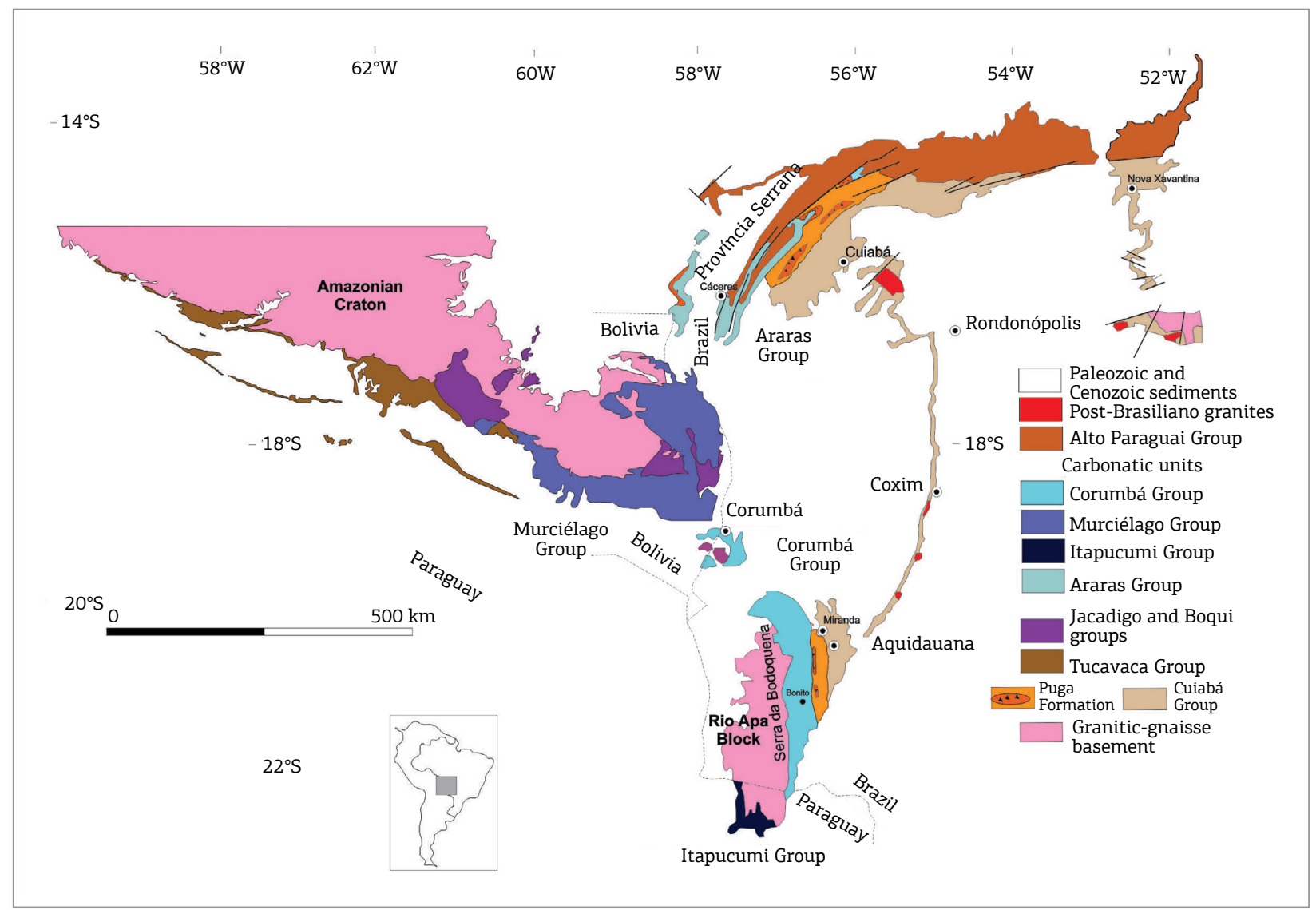

Figure 2. Simplified geological map of the Paraguay Belt showing the areas of outcrop of the Araras, Cuiabá, Corumbá, Itapucumi and the Murciélago groups (modified from Boggiani et al. 2010). 
d'Oeste Formation), a dark gray laminated lime-mudstone and shale (Guia Formation), and a shallow-water dolostone succession (Nobres Formations) bounded by flooding surface related to an abrupt sea-level rise characterized by a coarsening-upward succession from deep-shale to shallow limestone stromatolites (Pacu Formation).

The basal Mirassol d'Oeste Formation is characterized by laminated dolostone, exhibiting microbialite, wave ripple, and fan-like crystals (Nogueira et al. 2003; Nogueira \& Riccomini 2006; Alvarenga et al. 2008). This 25-m-thick cap dolostone yielded negative $\delta^{13} \mathrm{C}$ values from $-10.5 \%$ to $-3.0 \%$ and $\delta^{18} \mathrm{O}$ values from -8.2 to -1.3\%o VPDB (Nogueira et al. 2003, 2007; Alvarenga et al. 2004, 2008; Font et al. 2006), with high and variable ${ }^{87} \mathrm{Sr} /{ }^{86} \mathrm{Sr}$ ratios $(\mathrm{Sr}$ content $<100 \mathrm{ppm}$ ) and high $\mathrm{Mn} / \mathrm{Sr}$ ratios (> 18), interpreted as indication of post-depositional diagenetic alteration (Alvarenga et al. 2008). The $\delta^{13} \mathrm{C}$ chemostratigraphic pathway for the basal Ediacaran cap-carbonate (Marinoan) is comparable with $\delta^{13} \mathrm{C}$ stratigraphic profiles worldwide. Marinoan cap-carbonates are described in the Sáo Francisco paleocontinent (Caxito et al. 2012; Alvarenga et al. 2014), southern Paraguay (Boggiani et al. 2003), and Sergipano belts (Sial et al. 2010), and in different paleocontinents (Amazonia, Arabia, Arctic, Alaska, Australia, Baltic, Congo, Kalahari, India, Laurentia, Siberia, South China, Mongolia, and West Africa; see Hoffman 2011).

The cap dolostone of the Mirassol d'Oeste Formation is succeeded by transgressive, deep-platformal deposits of dark gray laminated lime-mudstone and shale of the Guia Formation, reaching up to $250 \mathrm{~m}$ thick in the middle shelf domain (Nogueira et al. 2007; Riccomini et al. 2007; Alvarenga et al. 2004, 2008, 2011). These trangressive deposits are exposed along more than $200 \mathrm{~km}$ from West to East (Alvarenga et al. 2008, 2009). Carbon isotope data for rocks of the Guia Formation revealed predominantly negative $\delta^{13} \mathrm{C}$ values, from -3.5 to $+0.1 \%$, and $\delta^{18} \mathrm{O}$ values from $-13.5 \%$ o to $-6.3 \%$ (Alvarenga et al. 2004, 2008; Figueiredo 2006; Nogueira et al. 2003, 2007). ${ }^{87} \mathrm{Sr} /{ }^{86} \mathrm{Sr}$ ratios for limestones with higher $\mathrm{Sr}$ content (> $750 \mathrm{ppm}$ ) and low $\mathrm{Mn} / \mathrm{Sr}$ ratios $(<0.2)$ range from 0.7076 to 0.7078 (Alvarenga et al. 2008, 2011).

The Nobres Formation consists of a light gray dolostone in a shallow-water succession $(900-1100 \mathrm{~m})$, showing increasing $\delta^{13} \mathrm{C}$ values from base to top, ranging from $-2.2 \%$ o to $+2.7 \%$ o in the first hundred meters, while in the upper dolostone $\delta^{13} \mathrm{C}$ values reach $+9.6 \%$ (Fig. 3). $\delta^{18} \mathrm{O}$ values range from -4.7 to $-0.1 \%$ (Pinho et al. 2003; Alvarenga et al. 2004; Figueiredo et al. 2006; Nogueira et al. 2007).

A package of about 300-m-thick shale and limestone was recently described as the upper unit of the Araras Group (Souza et al. 2012). C-isotope analyses for the uppermost $70 \mathrm{~m}$ of stromatolitic limestones include $\delta^{13} \mathrm{C}$ values from
$+6.6 \%$ o to $+8.9 \%$, while ${ }^{87} \mathrm{Sr} /{ }^{86} \mathrm{Sr}$ ratios are nearly constant, between 0.7087 and 0.7088 (Souza 2015). The record of the Gaskiers glaciation (Serra Azul Formation) is observed above an erosional surface atop the upper Araras Group, with the Pacu Formation preserved only near the Serra Azul in the eastern part of the North Paraguay Belt (Souza 2015).

Facies distribution, stratigraphy and the $\delta^{13} \mathrm{C}$ stratigraphic profile for the Araras Group match those for the middle Tsumeb Subgroup in Namibia, supporting an Ediacaran age for the Araras Group (Fig. 3). The upper portion of this group shows high $\delta^{13} \mathrm{C}$ values and high ${ }^{87} \mathrm{Sr} /{ }^{86} \mathrm{Sr}$ ratios, suggesting deposition in the late Ediacaran.

Toward the deeper parts of the basin, carbonate deposition was replaced by fine-grained deposits with low sedimentation rates. Facies and stratigraphic data coupled with $\mathrm{C}$ and $\mathrm{O}$ isotopes are an evidence of lateral equivalence of the lower units of the Araras Group wherein the Guia syncline, over $250 \mathrm{~m}$ thick at the edge of the basin, can be regarded as the break of the carbonate shelf (Alvarenga et al. 2004, 2008, 2011). The studied succession in the Guia syncline consists of 150-m-thick black-to-gray lime mudstone and shale with $\delta^{13} \mathrm{C}$ values from -2.5 to $-1 \%$. The $\delta^{13} \mathrm{C}$ stratigraphic profile in this syncline shows a clear correlation with the Guia Formation at the Cáceres region, $250 \mathrm{~km}$ away to southwest. At the Cáceres and Nobres region, a thick succession of shallow-water dolostones over $1000 \mathrm{~m}$ thick (Nobres Formation) overlies the Guia Formation. The sedimentary rocks of the Guia syncline were deposited in a deeper basin, outside the carbonate shelf, where pelitic sediments are found in its inner portion.

Ca isotopic compositions of post-glacial carbonate successions in central Brazil (Mirassol D’Oeste-Cáceres and Tangará) have been reported by Silva-Tamayo et al. (2010). The basal dolostones display ${ }^{44 / 40} \mathrm{Ca}$ values between 1 and $0.7 \%$, while the overlying limestones show a negative Ca-isotope excursion to values around $0.1 \%$, followed by a positive shift to $2.0 \%$ values and, then, stabilize upsection to values between 0.6 and $0.9 \%$. This Ca-isotope secular variation trend is similar to those of Marinoan post-glacial carbonate successions in Namibia, suggesting that the perturbation of the marine Ca cycle was, perhaps, global.

\section{RIO APA CRATONIC BLOCK AND SOUTHERN PARAGUAY BELT: CORUMBÁ GROUP}

\section{Corumbá Group}

The Corumbá Group is an important stratigraphic unit due to its good preservation, geochronological constraints, and 
metazoan fossils in its upper unit, the Tamengo Formation (Almeida 1965; Boggiani, 1998; Gaucher et al. 2003; Alvarenga et al. 2009; Boggiani et al. 2010; Spangenberg et al. 2014). This unit bears Cloudina and Corumbella fossils associated with volcanic ash levels at the top, which yielded a U-Pb SHRIMP age of $543 \pm 2 \mathrm{Ma}$ (Babinski et al. 2008).

The $80-200$-m-thick Tamengo Formation is characterized by black, pure limestone with organic

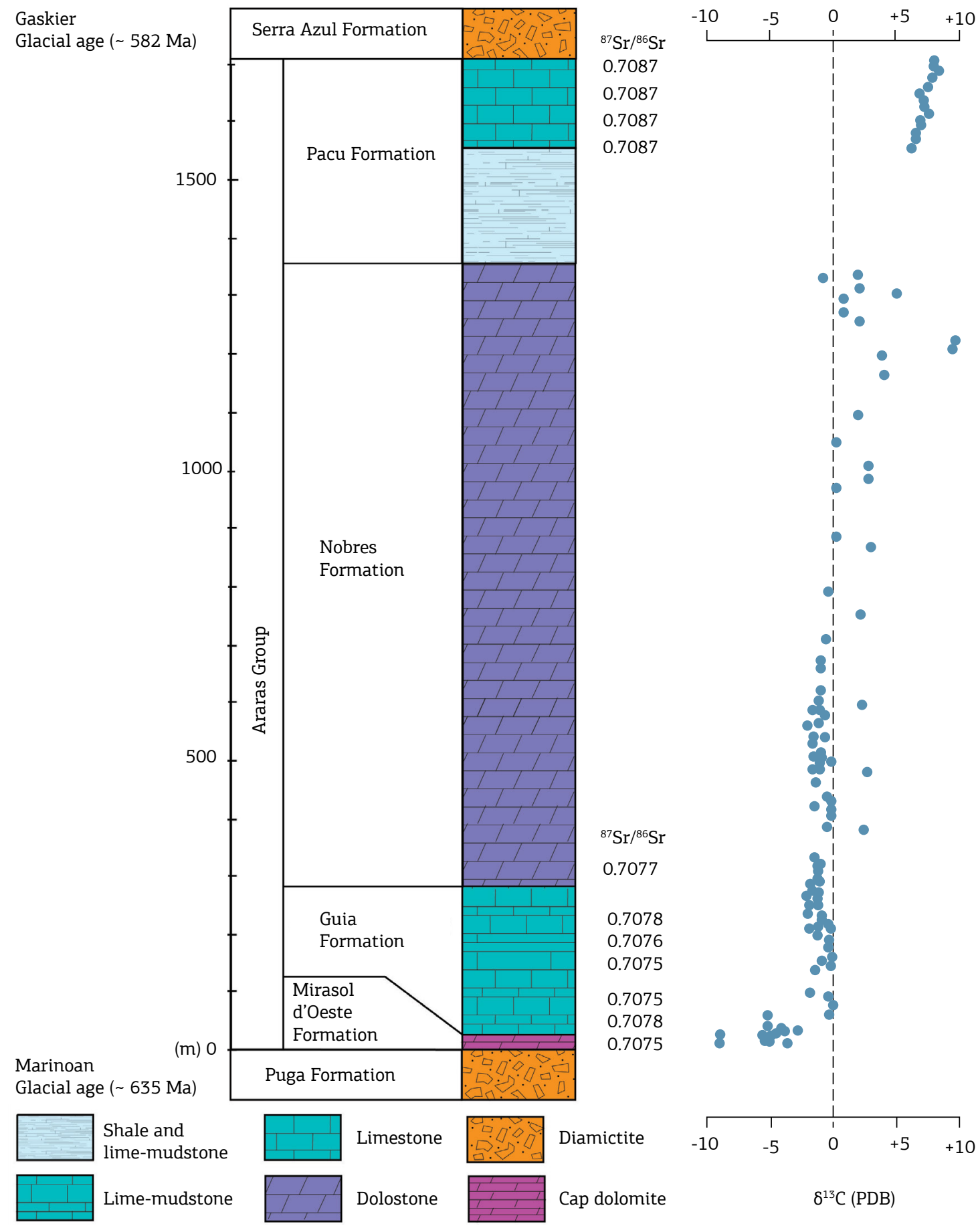

Figure 3. Stratigraphic section and variations of $\delta^{13} \mathrm{C}$ and ${ }^{87} \mathrm{Sr} /{ }^{86} \mathrm{Sr}$ for the Araras Group (data from Nogueira et al. 2003, 2007; Alvarenga et al. 2004, 2008; Font et al. 2006, Figueiredo 2006, Souza 2015). 
shale intercalations and rhythmite (black limestone/ organic shale), interpreted as deposited in a shelf context (Fig. 4). The metazoan fossils have been observed only in outcrops around Corumbá and Ladário towns, where shallow water conditions prevailed during deposition, attested by hummocky and other cross-bedding structures in grainstones. The Tamengo Formation is the best studied among the units of the Corumbá Group due to its fossil content, C-isotope behavior and the possibility that it may have recorded the Precambrian-Cambrian boundary.
The base of the Corumbá Group is characterized by conglomerate and arkose of the Cadieus and Cerradinho formations, which are restricted to the western border of the Serra da Bodoquena (Almeida 1965; Fig. 4). The deposition of these terrigenous sediments is associated to the development of a rift basin (Boggiani, 1998; Gaucher et al. 2003), probably part of a rift system developed in the basement, the Rio Apa Block. The deposition of the Puga diamicite and the manganese/iron formation of the Jacadigo Group are likely associated to the development of this rift system (Urucum Massif; Trompette et al. 1998; Walde \&

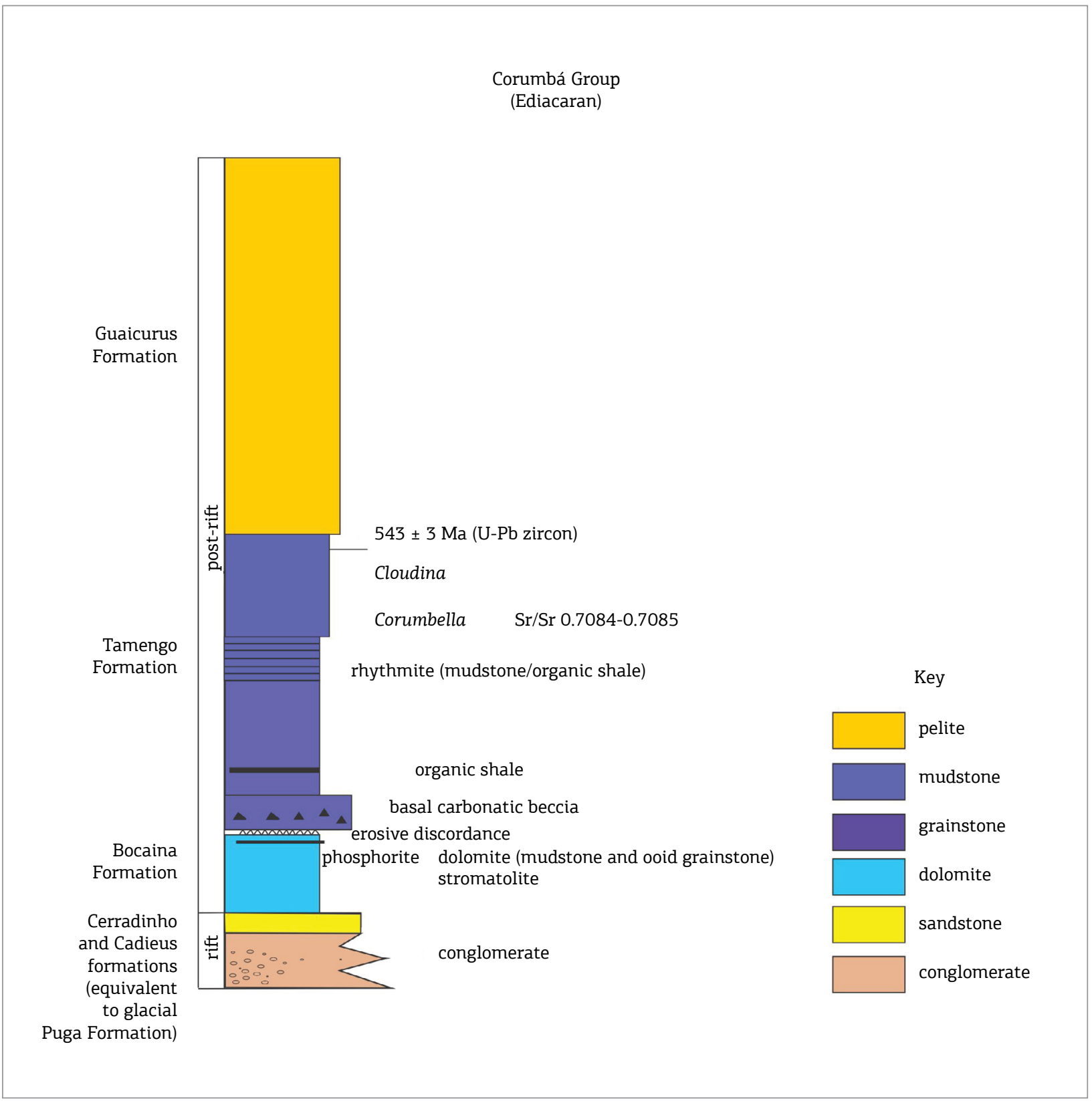

Figure 4. Stratigraphic column of the Corumbá Group, as originally defined by Almeida (1965), with modifications from Boggiani (1998). 
Hagemann 2007; Freitas et al. 2011). It is worth noting that the Puga Formation was originally described from the southern Paraguay Belt (Maciel, 1959), and is not necessarily time-correlative to the homonymous unit in the northern Paraguay Belt (Alvarenga et al. 2011).

The Bocaina Formation is related to thermal subsidence of the Corumbá Basin which promoted shallow deposition under warm water and high-evaporation conditions, responsible of stromatolite proliferation and primary (?) dolomite precipitation. The top of this unit is marked by the occurrence of phosphorite, related to upwelling that testifies the communication with the open ocean (Boggiani et al. 1993).

A strong sea-level drop marked the end of deposition of the Bocaina Formation, may be with its exposure, and was responsible for the deposition of an expressive carbonate breccia that defines the base of the Tamengo Formation (Boggiani 1998). This carbonate breccia contains clasts from the Bocaina Formation and from the granite-gneissic basement. The Tamengo Formation records an expressive transgression event contemporaneous to the appearance of metazoan fossils. This formation is overlain by siltstone and shale of the Guaicurus Formation that represents the end of carbonate sedimentation conditions and that probably straddles the Precambrian-Cambrian boundary.

The dolostones of the Bocaina Formation yielded $\delta^{13} \mathrm{C}$ values from zero to $\sim+3 \%$ and $\delta^{18} \mathrm{O}$ VPDB values $--3 \%$ (Boggiani 1998; Fontaneta 2012). Stronger fluctuation of C-isotope values is observed in the Tamengo Formation in which values of $--1 \%$ are common above basal breccias and at about $20 \mathrm{~m}$ toward the top, reaching nadir values of -3.6\%o (Boggiani et al. 2010; Spangenberg et al. 2014). A positive excursion to $+5 \%$ follows, which is associated with the first occurrence of Cloudina (Fig. 5). Above the positive C-isotope excursion, the Tamengo Formation is characterized by a plateau of positive values, around $+3 \%$ (Boggiani et al. 2010), where some $10 \mu \mathrm{m}$-pyrite framboids yielded high positive $\delta^{34} S$ values, between +35.9 and $+43.5 \%$ CDT. Values of ${ }^{87} \mathrm{Sr} /{ }^{86} \mathrm{Sr}$ in the $0.7085-0.7086$ range characterize limestones of the upper portion of the Tamengo Formation (typical of the Ediacaran-Cambrian boundary).

Carbonate rocks of the top of the Puga Formation diamictite at the Puga Hill in the Paraguay River are interpreted as a cap carbonate. This cap carbonate exhibits rhythmicity of lamination in a deep-red limestone with homogeneous $\delta^{13} \mathrm{C}$ values around -5\%o (Boggiani et al. 2003). The deposition of the Puga Formation has been assigned to the early Cryogenian, with youngest detrital zircons yielding ages of $706 \pm 9 \mathrm{Ma}$ and $706 \pm 12 \mathrm{Ma}$ (Babinski et al. 2013).

After about three decades of global chemostratigraphic studies of Neoproterozoic carbonate successions, there is a consensus that negative $\delta^{13} \mathrm{C}$ excursions follow the main glacial events, identified in Cryogenian cap carbonates, and two Ediacaran negative $\delta^{13} \mathrm{C}$ excursions, one below the first occurrence of skeletal organism (Shuram-Wonoka excursion) and a second one in the Precambrian-Cambrian boundary. One cannot assure that the negative $\delta^{13} \mathrm{C}$ excursion at the base of the Tamengo Formation is a primary feature, since it has not been observed in different sections of this formation, as happens elsewhere (e.g. Oman and Death Valley; Boggiani et al. 2010). It is possible that this negative $\delta^{13} \mathrm{C}$ excursion in the Tamengo Formation, associated with black, organic limestone, has resulted from oxidation during deep burial of organic matter. However, positive $\delta^{13} \mathrm{C}$ values in organic limestone in the same stratigraphic position were observed in this formation. This negative $\delta^{13} \mathrm{C}$ excursion is located just below a positive $\delta^{13} \mathrm{C}$ excursion, contemporary with the first occurrence of Cloudina. It is of paramount importance in unraveling whether the Shuram-Wonoka $\mathrm{C}$-isotope anomaly is a primary feature orjust a diagenetic artifact. If proved to be a primary one, this $\mathrm{C}$-isotope anomaly will encourage further investigation on its relationship with early animal life evolution.

\section{Itapucumí Group, Southern Paraguay Belt}

The study of South American Neoproterozoic successions has improved the comprehension of the bioevolutionary, climatic, and geotectonic phenomena coeval with the Rodinia supercontinent rifting. During this time interval, important subsidence cycles took place at the margins of the Amazonian, Pampia, and Rio de la Plata cratons, leading to the deposition of carbonatic and siliciclastic sequences in newly formed basins. These units, as the Corumbá (Brazil), Puncoviscana (Argentina), and Arroyo del Soldado (Uruguay) groups contain important Ediacaran fossils represented by microfossils and skeletal organisms as Cloudina sp. and Corumbella sp. In this context, the Itapucumí Group is one of the least known Neoproterozoic units (Fig. 6). This group, composed of carbonate and siliciclastic rocks, including ooid grainstones, marls, shales, and sandstones, occurs in northeastern Paraguay as a marginal belt that shows strong deformational pattern at its western edge and forms an almost undeformed sedimentary cover on the Rio Apa cratonic Block, a promontory of the Amazonian Craton (Campanha et al. 2010). The Rio Apa Block is delimited at its eastern portion by the Paraguay Belt, a W-vergent thrust-and-fold belt, which is composed of the Ediacaran successions of the Corumbá Group.

The Itapucumí Group is about $400 \mathrm{~m}$ thick and comprises siliciclastic rocks of the Vallemí Formation at the base (Fig. 7). These basal layers are composed of immature sandstones interbedded with basalts, covered by an expressive 


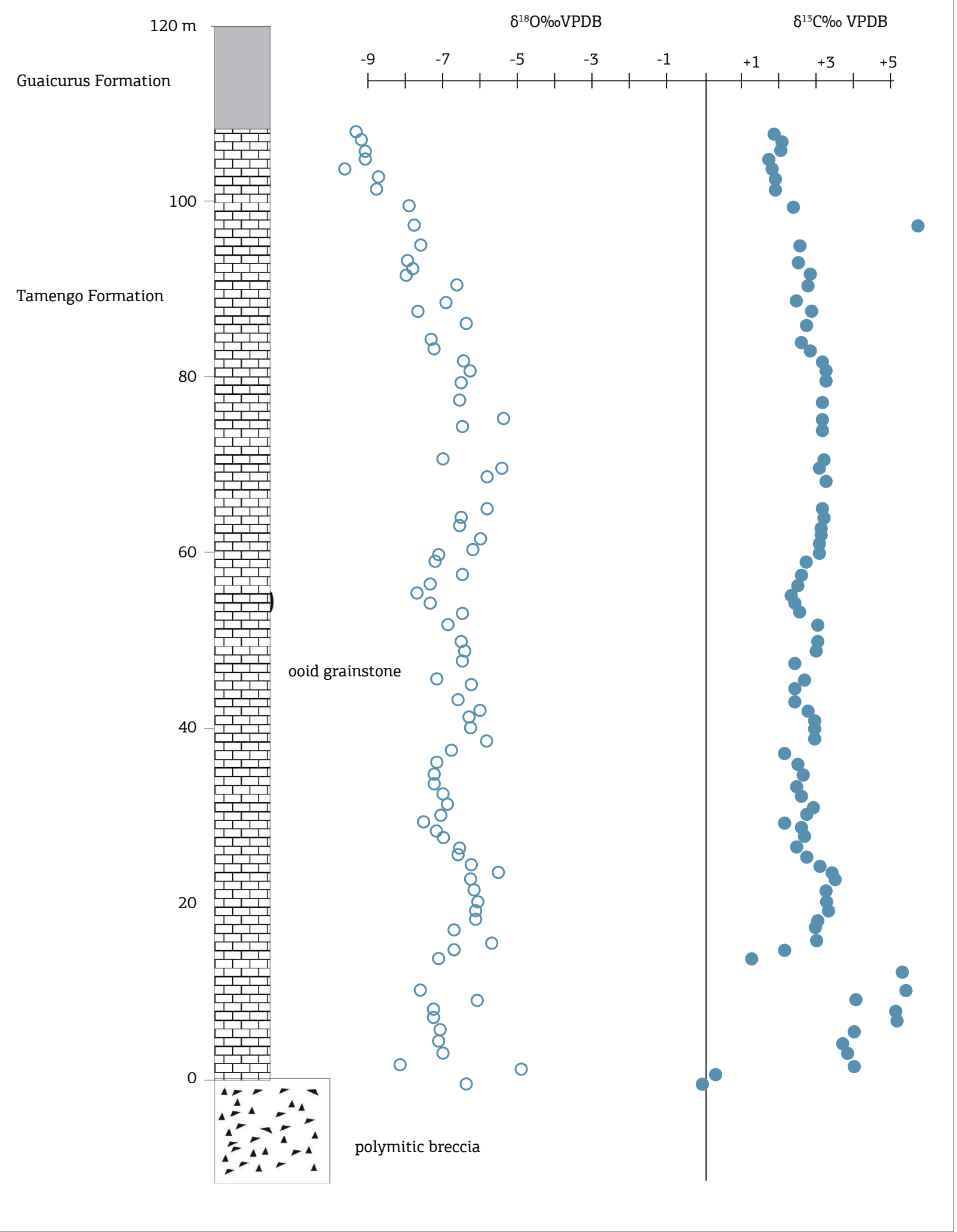

Figure 5. Stratigraphic column and high-resolution chemostratigraphic $\mathrm{C}$ and O-isotope data of the Tamengo Formation, Corumbá Group, in the eastern part of Laginha Mine. The contact between the basal breccias and overlying carbonates is faulted and the lower Tamengo Formation is missing (modified from Boggiani et al. 2010). 
sequence of red beds. This succession is followed by ooid grainstones, microbialites, and dolostones of the Camba Jhopo and Tagatiyá Guazú formations, and capped by dolostones, marls, and pelites of the Cerro Curuzú Formation (Warren et al. 2010; Warren 2011). Close to the Paraguay River, this unit has been metamorphosed in the lower-greenschist facies

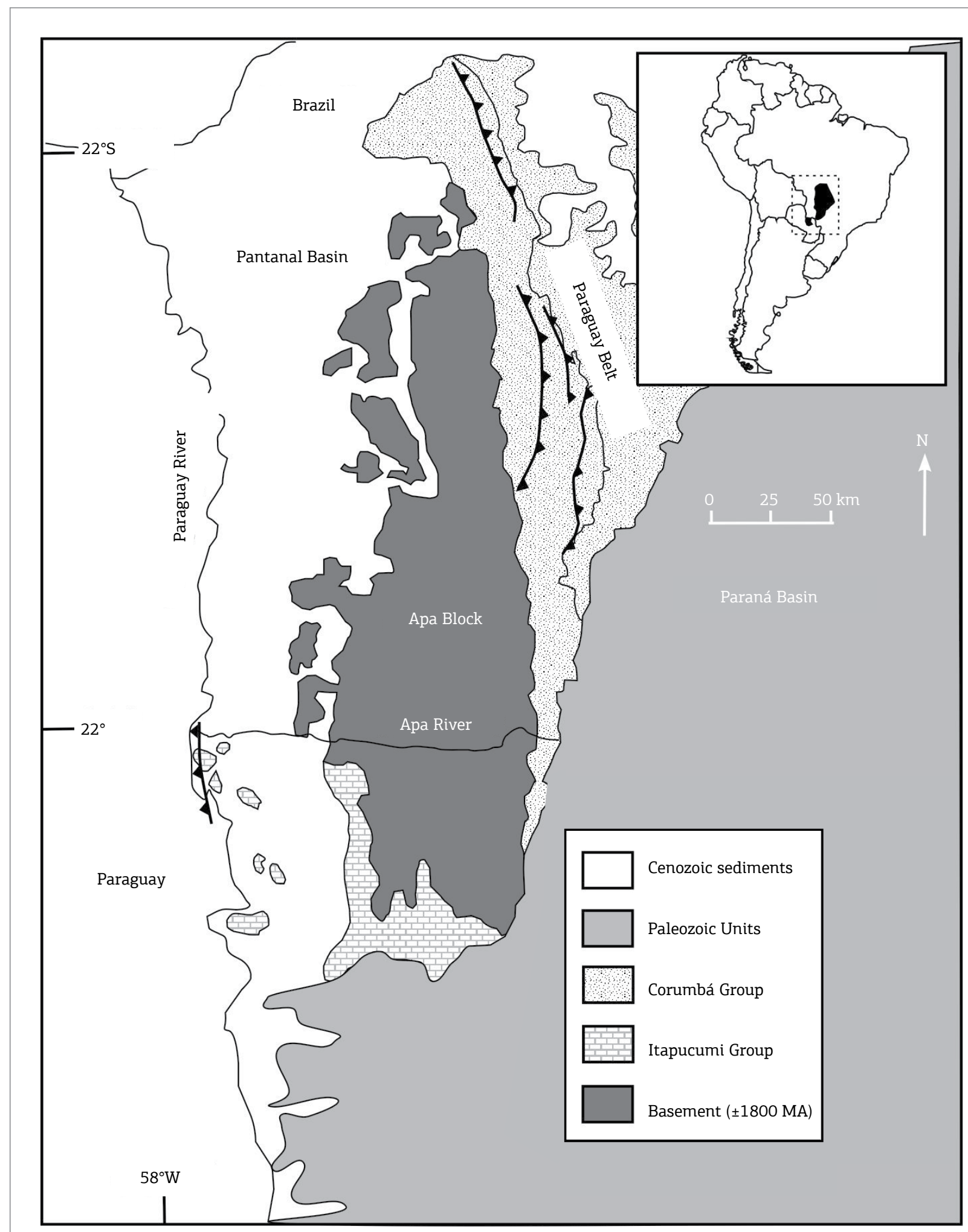

Figure 6. Summary geological map of the area of occurrence of the Apa Block, Itapucumi and Corumbá groups. 
and has been intensely deformed, showing E-vergent thrusts and folds, opposite to those of the Paraguay Belt, located in the other margin of the block (Vallemí Belt of Campanha et al. 2010). This western Domain of the Itapucumí Group is characterized by shelf successions of ooid grainstones of the Camba Jhopo Formation, deposited as beach spits and proximal coastal facies. East of these outcrops, the Tagatiya Guazú Formation is not deformed and constitute an extensive

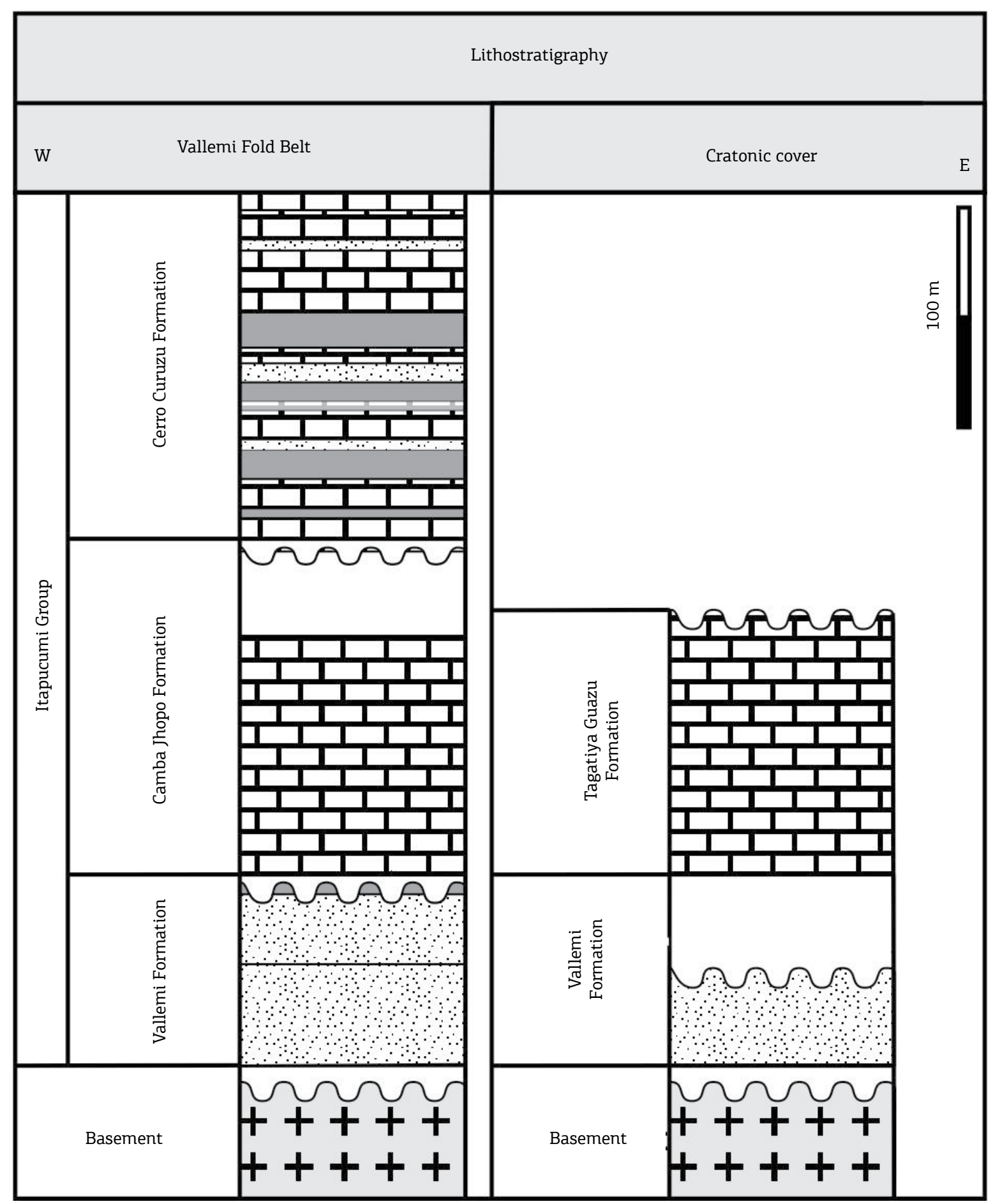

Figure 7. Lithostratigraphy of the Itapucumi Group in the western portion of theVallemi Belt. Modified from Warren 2011). 
cratonic cover comprised by lagoonal facies deposited in inter- to supratidal context, associated with laminated microbialites and thrombolites containing Cloudina sp., Corumbella werneri, and simple ichnofossils (Boggiani \& Gaucher, 2004; Warren et al. 2011, 2012). Covering these successions there are pelites, marls, and grainstones of the Cerro Curuzú Formation representing deep-shelf depositional systems with siliciclastic contribution (Warren et al. 2010; Warren 2011).

The stratigraphic architecture of the Itapucumí Group successions is similar to that described for the Corumbá Group which is formed by siliciclastic deposits of the Cerradinho, Cadieus, and Puga formations at the base, overlain by carbonate rocks of the Bocaina and Tamengo formations, and pelitic sediments of the Guaicurus Formation at the top. The carbonate units of the Corumbá Group are representative of shallow-water shelf deposits grading into deep-water successions in a transgressive environment, in the same way that lagoon depositional systems grade toward the top to oolitic shoals and coastal bars in the Itapucumí Group. Toward the top of both units, deeper deposits with siliciclastic contribution are representative of retrogradational conditions, which characterizes regional (probably eustatic) sea-level rise. Cloudina sp. and Corumbella werneri fossils found in the lower portion of the Tagatiyá Guazú Formation attest to a terminal Ediacaran age and the paleoecologic and chronostratigraphic correlation with the Tamengo Formation (Warren et al. 2011, 2012).

C-isotope ratios do not show large fluctuations across the Itapucumí Group as commonly observed in Neoproterozoic $\delta^{13} \mathrm{C}$ records (Fig. 8). The Itapucumí carbonate succession yielded positive $\delta^{13} \mathrm{C}$ values, ranging from +0.2 to $+3.8 \%$ o (Warren et al. 2010; Warren 2011). Levels of microbialites that contain Cloudina and Corumbella (Tagatiyá Guazú Formation) present average $\delta^{13} \mathrm{C}$ value of $+2.45 \%$ o (Warren 2011), supporting the stratigraphic correlation between this unit and the Tamengo Formation in the Corumbá Group. Preliminary ${ }^{87} \mathrm{Sr} /{ }^{86} \mathrm{Sr}$ data of the Camba Jhopo/Tagatiyá Guazú and Cerro Curuzú formations, exhibit mean value of 0.7086 , further reinforce this correlation.

Therefore, paleontological, stratigraphical, and isotopic data support the correspondence between the Itapucumí and Corumbá groups, confirming their coeval evolution (Fig. 9). The divergent patterns of tectonic vergence between these two belts could be, perhaps, explained by having the Rio Apa Block acting as a rigid barrier during a Cambrian orogenic event related with the final closure of the Clymene Ocean (Warren 2011; Campanha et al. 2010). Alternatively, it could represent a different unit altogether (Poiré, 2014).

\section{Murciélago Group, Tucavaca Belt, Bolivia}

Neoproterozoic rocks in Bolivia are found in the Tucavaca Belt, near the town of Santa Cruz de La Sierra, in the southern portion of this country. Litherland \& Bloomfield (1981) have summarized a general picture of the geology of the country, McNamee (2001) a model for onset of the Tucavaca Basin, and Pinto-Vasquez (2001), some further details of its geological evolution.

Rocks in the northeastern boundary of the Tucavaca Belt (Fig. 2) are in contact with the Mesoproterozoic basement (Litherland et al. 1986) and in its southwestern boundary, are covered by Quaternary sedimentary rocks of the ChacoBenian Plains regarded as a foreland basin of the Andean Belt. Rocks of the Tucavaca Belt are observed along the railway between the towns of Santa Cruz, in Bolivia, and Corumbá, in Brazil (Hess 1959). Their outcrops can be divided into two groups:

1. one observed near the Bolivia-Brazil boundary, at the Brazilian side, in continuity with the Paraguay Belt that encompasses a thick pack of rocks of the Boquí Group overlain by carbonate rocks of the Murciélago Group, equivalent to the Jacadigo and Corumbá groups of the Paraguay Belt (Chamot 1963); and

2. a second group that corresponds to the Tucavaca Belt, named by Hess (1959), and that extends for over $500 \mathrm{~km}$. These rocks exhibit a NW-SE regional trend, differently from rocks in the Paraguay Belt which are aligned in the N-S direction.

The stratigraphy of the Tucavaca Belt encompasses the Boquí and Tucavaca groups. The Boquí Group is represented by rocks deposited unconformably in a rift basin parallel to the Sunsas Belt, the basement. This group is formed by rocks deposited in three environments:

1. fan-conglomerates of the San Francisco Formation $(-2000 \mathrm{~m}$ thick);

2. intertidal and lagoonal sediments of the Colmena Formation ( $-900 \mathrm{~m}$ thick); and

3. submarine mudflows of the Cahama Formation $(\sim 1,500 \mathrm{~m}$ thick).

In the region of Porto Suarez and Mutún, one observes a volcanogenic basal unit below the sequence of rocks included in the Jacadigo Group equivalent to the Cuarrí Formation of the Boquí Group. This volcanic unit has been called Pimienta Formation and the overlying rocks are regarded as tillites. They include other glacial/periglacial deposits as iron and manganese formations (IF) of the Urucum Formation, in the Brazilian side of the Paraguay Belt. 


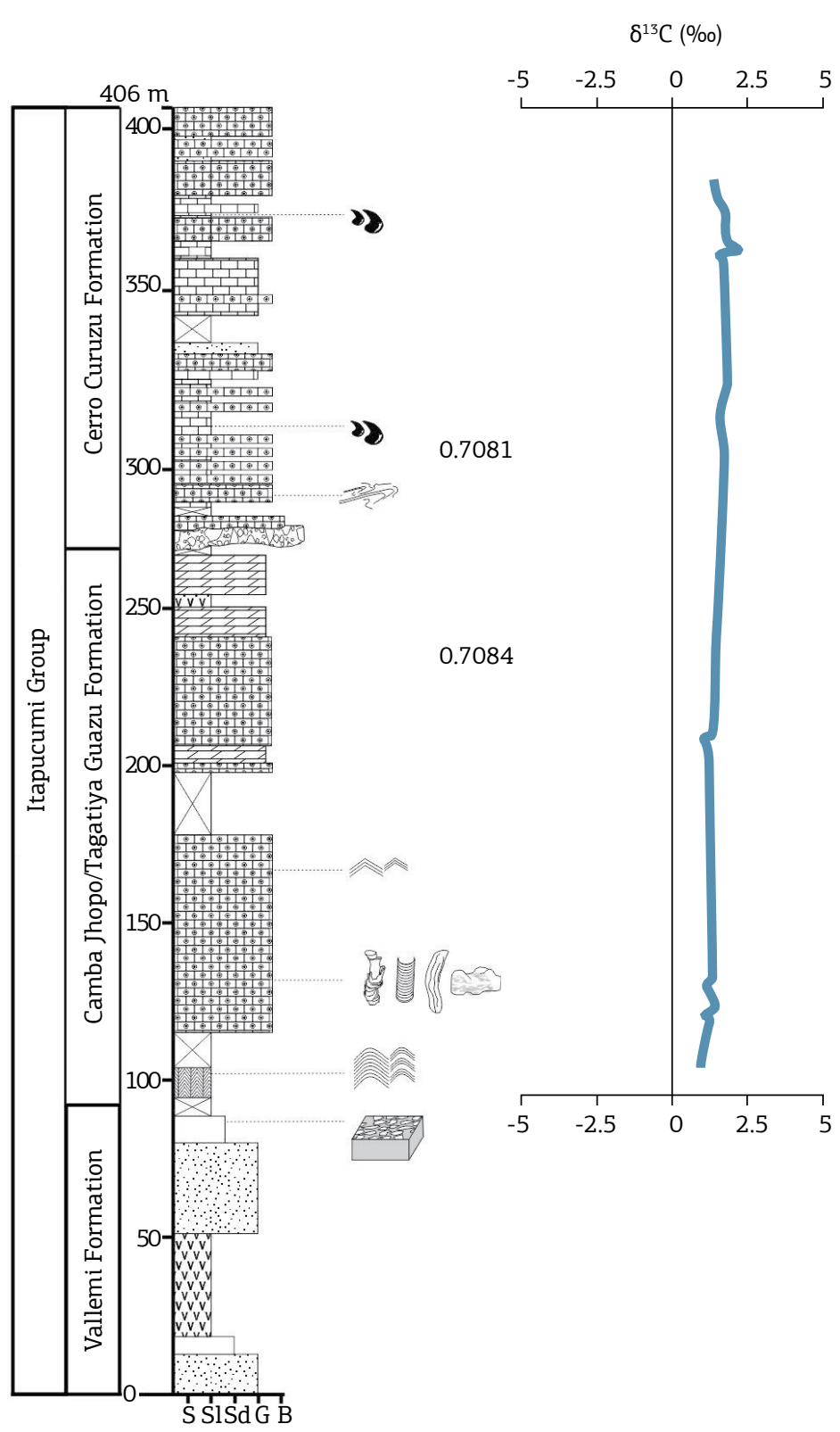

\begin{tabular}{|c|c|c|c|c|c|}
\hline \multicolumn{2}{|c|}{ Lithology } & & Sandstone & \multicolumn{2}{|c|}{ Other structures } \\
\hline & Ooidgrainstone & & Pelite & & Slumps \\
\hline & & & & & Tepees \\
\hline & Grainstone & & Basalt & & Bitumen \\
\hline $\begin{array}{l}15 \\
4\end{array}$ & Dolostone & MISS and & bioinduced structures & Foss & \\
\hline 资 & Mudstone & & & 3 & Cloudina \\
\hline 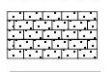 & Mari & & MISS - Kinneyia & & Corumbella \\
\hline a & Conophyton & & Thrombolite & & \\
\hline 8000 & Conglomerate & $\Leftrightarrow$ & Ichnofossil & 0.7081 & ${ }^{87} \mathrm{Sr} /{ }^{86} \mathrm{Sr}$ ratio \\
\hline
\end{tabular}

Figure 8. C-isotope chemostratigraphy for the Itapucumi Group (modified from Warren 2011) 
The Tucavaca Group has a total thickness of 2,500 m and overlaps the Cahama Formation (youngest unit of the Boquí Group), encompassing a sequence of conglomerates (Pacobilo Formation), finely laminated, gray to pinkish limestones (Pororó Formation), coarse, sometimes micaceous sandstones with rare dropstones (Bocamina Formation). On top of the last one, one observes shales, claystones, and siltites (Pesenema Formation) with intercalations of clastic material (Tarumá Member), metamorphosed at low grade. The Bocamina Formation is stratigraphically correlated to the Motacú (shale and sandstone) and Piococa (arkose) formations that occur in the Tucavaca syncline between the localities of Taperas and Quimoné.

Sandstones and limestones have been identified next to the locality of Murciélago in the region of Porto Suárez, leading to the definition of the homonymous group. The horizontal sedimentary rocks of the Murciélago Group are over $500 \mathrm{~m}$ thick and overlap rocks of the Boquí Group. These rocks have been correlated with the Pororó Formation of the Tucavaca Group.

The Tucavaca aulacogen represents a failed rift arm according to Trompette et al. (1998) which may mark the boundary between the Río de la Plata and Amazonian cratons (Gaucher et al. 2009b). The sedimentary infill of this aulacogen, represented by the Boquí, Murciélago, and Tucavaca groups, correlates with the Jacadigo and Corumbá groups of the southern Paraguay Belt (Avila Salinas 1992), showing that the opening of the Tucavaca Basin took place at approximately $600 \mathrm{Ma}$ (Gaucher et al. 2009b). A rhyolite associated with the Boquí Group in Bolivia (nearby Puerto Suárez) yielded K-Ar age of 623 to $715 \mathrm{Ma}$ (Avila Salinas 1992; Trompette et al. 1998). The emplacement of this rhyolite is probably related to continental rifting and, thus, drifting and opening of the Brazilides Ocean in that area is unlikely to have commenced prior to about $600 \mathrm{Ma}$ (Gaucher et al. 2009).

Fernández-Ramírez et al. (2009) collected stratigraphically seventeen samples of massive limestone and dolostone of the Murciélago Group with horizontal stratification in a continuous profile at a 30-m-high quarry, located between the Roboré town and Santo Corazón village, $4 \mathrm{~km}$ from Murciélago. Poorly sorted sandstones and diamictites, stratigraphically below the carbonates of the Murciélago Group were collected at about $1 \mathrm{~km}$ to the northeast from the site of collection of the carbonates, following the same road. $\delta^{13} \mathrm{C}$ values for these carbonates are all negative, varying from -0.9 to $-1.8 \%$, and $\delta^{18} \mathrm{O}$ from $-4.1 \%$ to $-6.3 \%$ o VPDB (Fig. 10).

\section{SÃO FRANCISCO PALEOCONTINENT AND SURROUNDING BELTS}

The Neoproterozoic sedimentary cover of the São Francisco Craton (SFC) is represented by dominant carbonate sedimentation over the cratonic area, deposited in epicontinental (intracratonic) basins. Surrounding the cratonic area, the extensive process of sedimentation provided correlative siliciclastic and carbonate successions

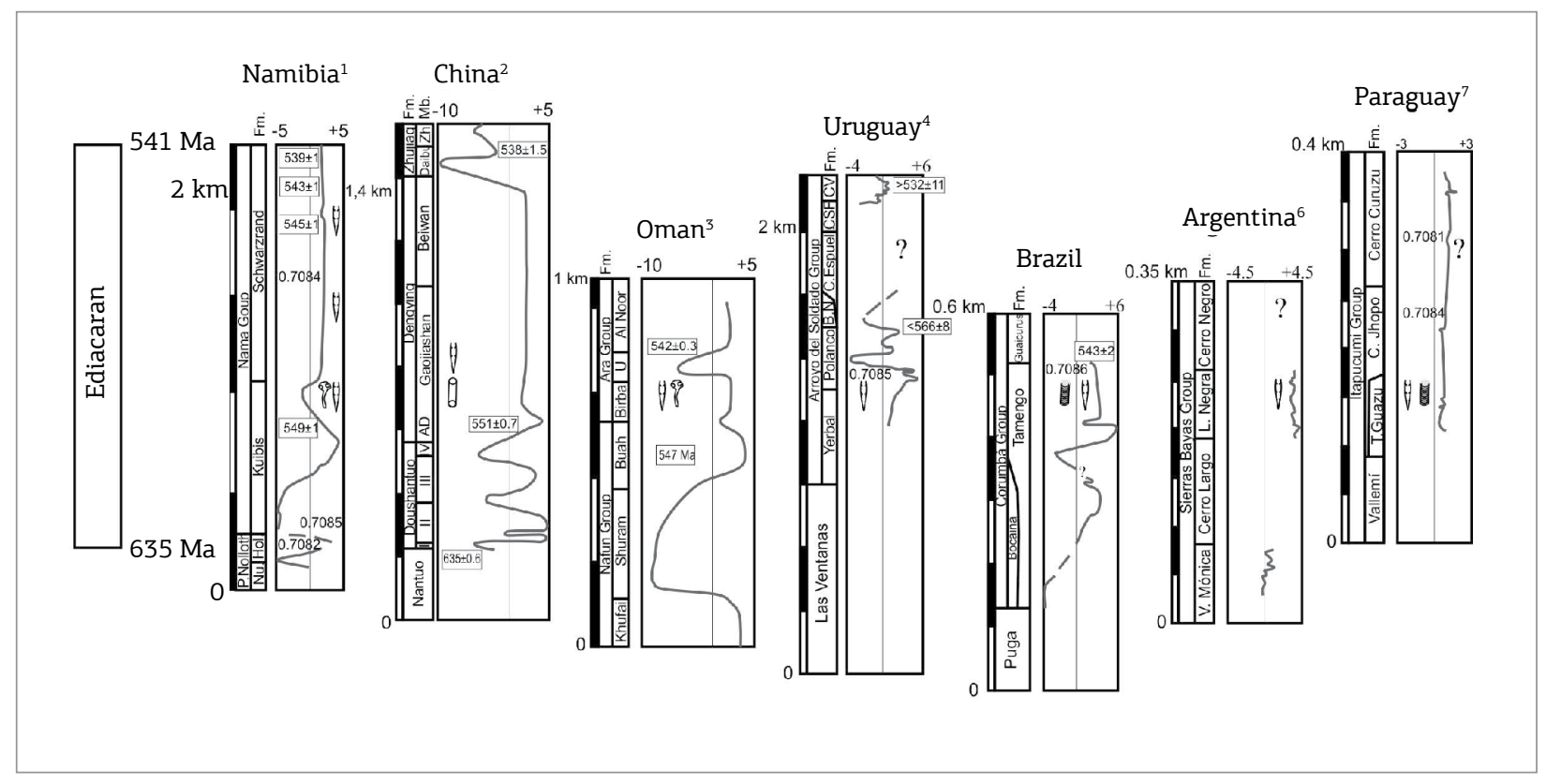

Figure 9. C-isotope chemostratigraphic correlation of the Ediacaran units of the Itapucumi Group with wellknown Ediacaran groups worldwide (Namibia, Oman, China, Argentina, Uruguay, Paraguay and Brazil). Modified from Warren et al. 2011. 
in passive-margin basins present in the Brasília, Araçuaí, Sergipano, Riacho do Pontal and Rio Preto belts, and Rio Pardo Basin (Fig. 11). These belts are marked by intense folding and overthrusting. The intracratonic sedimentary cover is only deformed in the peri-cratonic areas, near the foldbelts. They are preserved in isolated basins and sub-basins in Minas Gerais, Goiás, and Bahia. They include basal assemblages of Paleoproterozoic and Mesoproterozoic ages but here we will restrict the discussion to the Neoproterozoic sedimentary assemblages comprising the São Francisco Supergroup (Alkmim \& Martins-Neto 2001; Martins-Neto \& Alkmim 2001), which is characterized by a glaciogenic mega-sequence at the base, a carbonate-platform mega-sequence (marine) and a molasse mega-sequence above, separated by first-order unconformities (Misi et al., 2007; Misi et al. 2011 and references therein).

Correlations between the stratigraphic successions using parasequence boundaries observed in the different basins and sub-basins, petrographic investigation, and high-resolution chemostratigraphic profiles (mainly ${ }^{87} \mathrm{Sr} /{ }^{86} \mathrm{Sr}, \delta^{13} \mathrm{C}, \delta^{18} \mathrm{O}$ and $\delta^{34} S$ ), have been suggested by several authors during the last 20 years (Sial et al. 2010 and references therein). In the following sections, we will discuss the progress of these studies in the epicontinental (intracratonic) and passive-margin basins (foldbelts).

\section{Neoproterozoic intracratonic basins}

The intracratonic successions include the Bambuí Group in the São Francisco Basin (states of Minas Gerais, Goiás and Bahia) and the Una Group in the Irecê, Campinas, Una-Utinga, and Ituaçu sub-basins (Bahia), covering more than $60 \%$ of the cratonic area. Despite the proliferation of different names, it is possible to demonstrate the correlation of stratigraphic successions along thousands of kilometers.

A common tectonic evolution is postulated for these basins, during the Neoproterozoic times. Although some authors consider that the sediments have accumulated in foreland basins during compressive tectonic events (e.g. Dardenne 2001, Martins-Neto 2001, among others), others argument in favor of extensional tectonism associated with

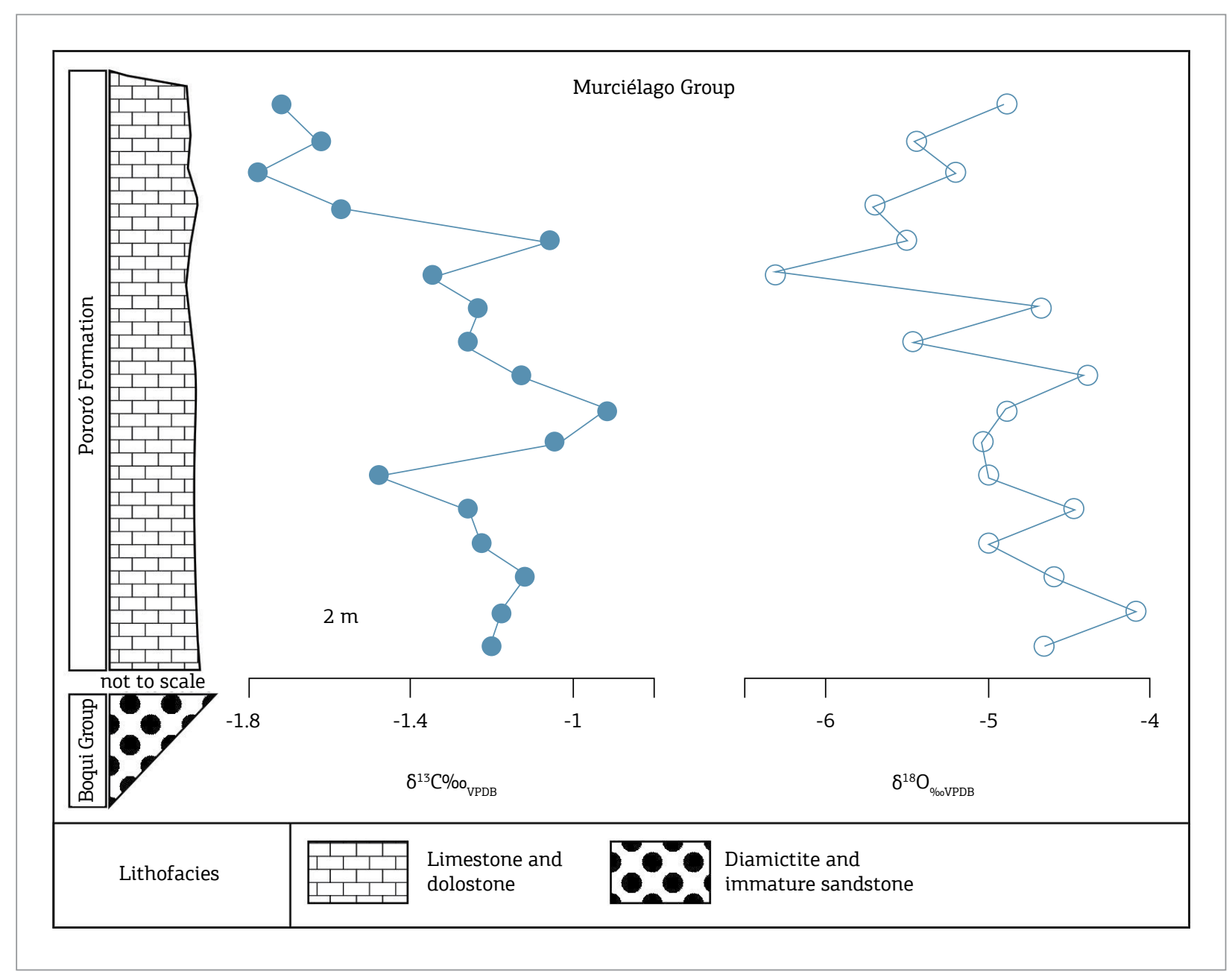

Figure 10. C-isotope chemostratigraphy for carbonates of the Murciélago Group, Bolívia. 
glacial diamictites in the basal section (D'el Rey Silva 1999; Misi et al. 2011). According to Misi et al. (2007), an extensional stage related to the break-up of the Rodinia supercontinent $(900-600 \mathrm{Ma})$, responsible for the glaciogenic and marine carbonate mega-sequences, is partially co-incident with the Brasiliano-Pan African orogeny (650 - $500 \mathrm{Ma})$, which is responsible for the molasse mega-sequence sedimentation at the upper section. In addition, this collisional stage is determinant of the present structural configuration of the basins, with thrust faults, detachment faults, and verging flexural folds in the peri-cratonic area, including the fold belts (Misi \& Veizer 1998). Extensive faults, aligned

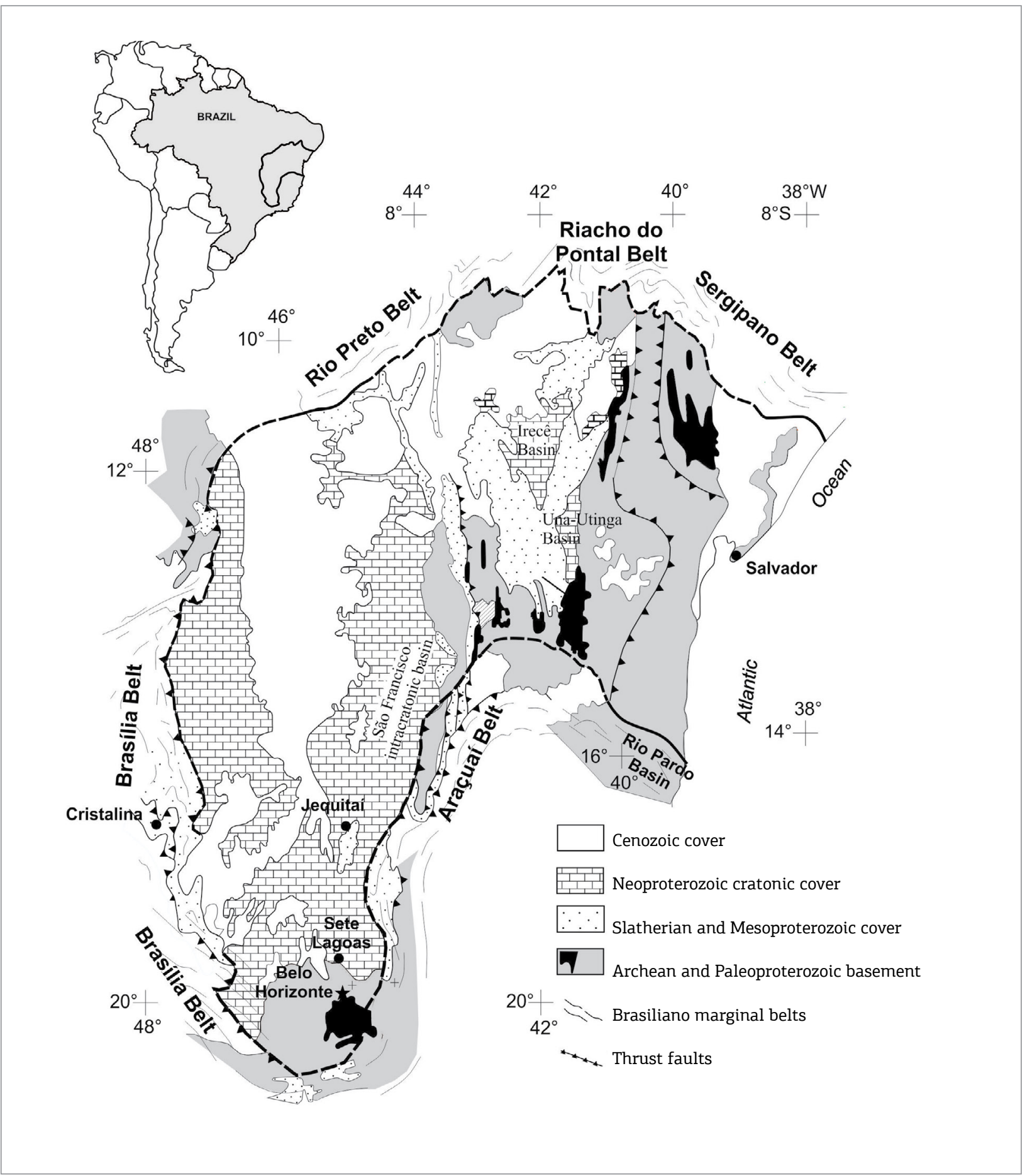

Figure 11. Simplified geological map of the Sao Francisco craton showing the Neoproterozoic cover and surrounding belts (modified from Sial et al. 2010). 
NNE-SSW, intersecting the Neoproterozoic cover and the older Proterozoic basement (Alkmim et al. 1996; Misi 1999) may represent basement structures reactivated during sedimentation (Misi \& Veizer; 1998; Misi et al. 2014) (Fig. 11).

\section{Sequence stratigraphy}

The Bambuí and Una groups (São Francisco Supergroup) are formed by carbonate and siliciclastic successions distributed in the following megasequences (Fig. 11):

\section{Glaciogenic}

Glaciogenic diamictites are known to occur at least in two stratigraphic positions within Neoproterozoic successions of South America (see Misi et al. 2007 and references therein), but in the intratcratonic basins of the São Francisco Craton, they are clearly observed only below the carbonate (marine) platform megasequence, represented by the Jequitaí Formation (Bambuí Group: São Francisco Basin) and the Bebedouro Formation (Una Group: Irecê, Una-Utinga and Campinas sub-basins). However, Kaufman et al. (2008) have recognized diamictites in association with cap carbonates in Inhaúma district, $25 \mathrm{~km}$ from Sete Lagoas, to the East (Sambra Quarry). Although no diamictite has been observed in the area near this quarry, the possibility of correlation with the Inhaúma outcrop is considered in view of the negative $\delta^{13} \mathrm{C}$ shifts measured in the Sambra Quarry $(-5 \%$ ) as well as in the Inhaúma cap carbonate $(-2 \%)$, among others. In the Irecê sub-basin (Una Group), the presence of dolostones in the uppermost section (Unit B1) of the first megasequence showing negative $\delta^{13} \mathrm{C}$ shifts $(-4 \%$, Torquato $\&$ Misi 1977), may suggest a discrete glacial event (Fig. 12). No diamictite has been observed.

\section{Carbonate-dominated marine succession}

The facies here represented are formed by dolostone, marls, shale, and siltstone. Dardenne (1978, 1979 and 2000) subdivided the Bambui Group into the following units:

- Sete Lagoas Formation - Laminated limestone with dolarenite with teepee structures at the top and red dolostone at the basal section;

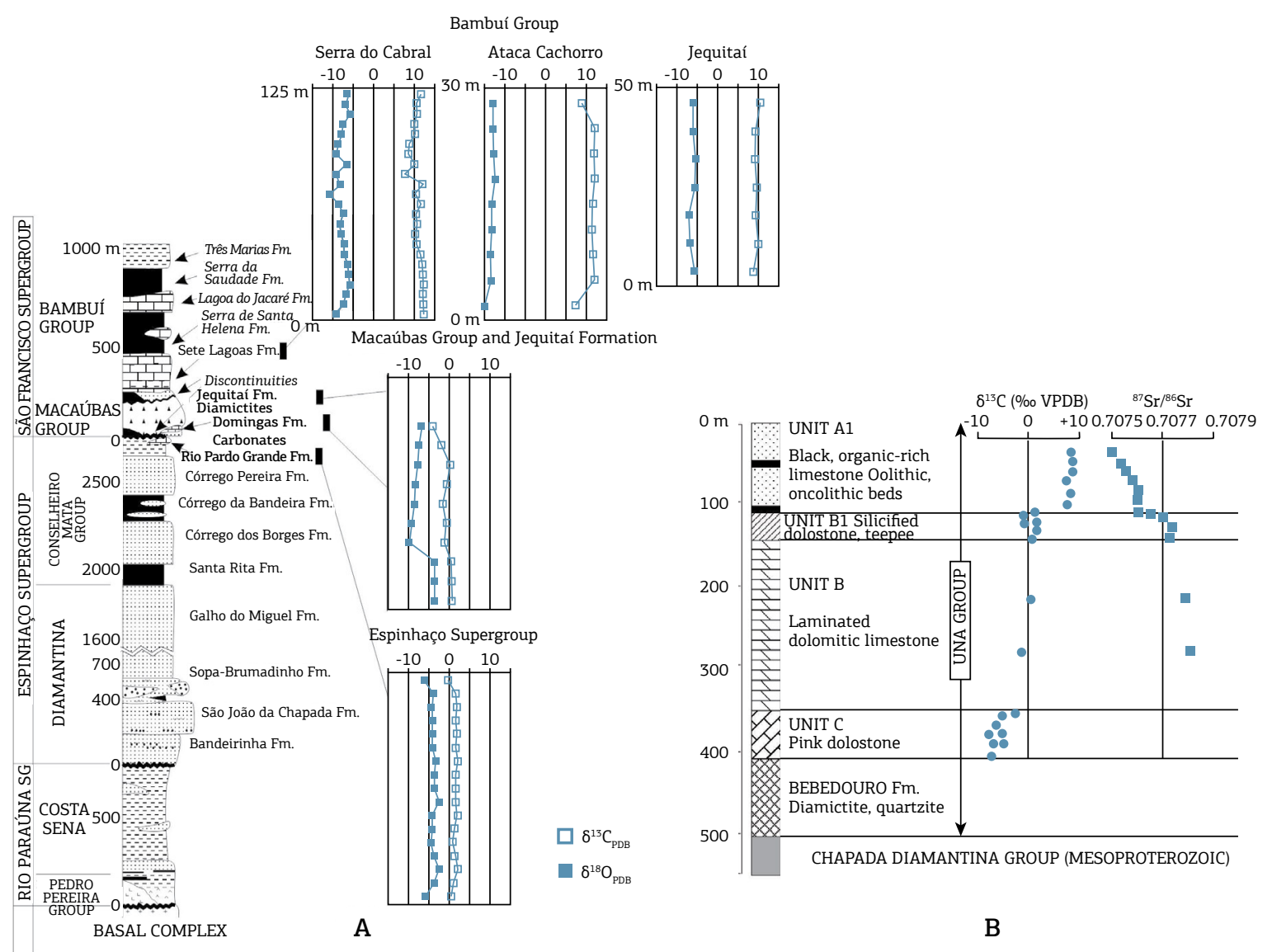

Figure 12. C-isotope chemostratigraphy for the Bambui (a) and Una (b) carbonate-dominated successions (modified from Santos et al. 2000; Misi et al. 2011) 
Serra de Santa Helena Formation - Marl, siltstones, fine sandstones, and intercalated limestones;

- Lagoa do Jacaré Formation - Black, organic-rich intercalated limestone;

- Serra da Saudade Formation - Siltstone, pelite, and intercalated limestone;

- The Salitre Formation of the Una Group has been subdivided into five units that correlate with those of the Bambui Group (Misi et al. 2011; Fig. 13).

\section{Siliciclastic continental (molasse) succession}

Arkose, siltstone, phyllite, and conglomerate form the Três Marias Formation of the Bambuí Group. These facies are related to foreland sedimentation at the end of the Brasiliano orogenesis. According to Brito Neves \& Cordani (1991), the contact between the Três Marias Formation and the Bambuí Group is erosional. These facies are not represented in the eastern side of the SFC (Irecê, Una-Utinga and Campinas sub-basins).

\section{Depositional ages: geochronology and isotopic records}

Lack of absolute gechronological ages is still a problem. In the absence of datable volcanic rocks, U-Pb ages on detrital zircons have been used during the last 15 years, resulting in controversial data when compared with other methods applied to the same stratigraphic intervals. For example, $\mathrm{Pb}-\mathrm{Pb}$ model age of $740 \pm 22 \mathrm{Ma}(\mathrm{MSWD}=0.66)$ from well-preserved sea-floor cements in the Sete Lagoas Formation (Babinski et al. 2007), considered the most consistent geochronological data until recently, is now contested by recent $\mathrm{U}-\mathrm{Pb}$ ages of detrital zircon $610 \mathrm{Ma}$ from the same stratigraphic interval, that is, possibly representing the maximum age of the Sete Lagoas Formation (Pimentel et al. 2011). On the other hand, U-Pb SHRIMP ages on detrital zircons from diamictites at the base of the Araçuaí Belt give a maximum age of $950 \mathrm{Ma}$ (Pedrosa Soares et al. 2000) and from clasts of diamictite from the Bebedouro Formation, central-eastern Bahia, reveal Archean and Paleoproterozoic populations, but the youngest detrital zircon dated $874 \pm 9 \mathrm{Ma}$ (Figueiredo et al. 2009). The discovery of the Neoproterozoic index fossil Cloudina sp. associated with other trace fossils in the Sete Lagoas Formation (lower Bambuí Group) has been reported by Warren et al. (2014) who propose, at least for exposures in central eastern Brazil, terminal Ediacaran age (550 - $542 \mathrm{Ma}$ ). Archean to Paleoproterozoic U-Pb SHRIMP ages of detrital zircons from carbonate platform of the basal and mid-sections of the Salitre Formation (Unit B, according to Misi \& Souto 1975, correlated to the mid-section of the Sete Lagoas Formation) have been reported by Santana et al. (submitted). Besides, they reported detrital zircon from a tuffite layer associated with deep-water mud-lithofacies, and possibly related to active volcanism in the passive marginal basins during mud sedimentation, with a concordia age of $669 \pm 14 \mathrm{Ma}$.

\begin{tabular}{|c|c|c|c|c|c|}
\hline \multicolumn{2}{|c|}{$\begin{array}{l}\text { Brasiliano Fold Belt } \\
\text { Passive-margin Basin }\end{array}$} & \multicolumn{3}{|c|}{ Intracratonic Basins } & $\begin{array}{l}\text { Sergipano Fold Belt } \\
\text { Passive-margin Basin }\end{array}$ \\
\hline \multicolumn{2}{|r|}{$\begin{array}{l}\text { VAZANTE GROUP } \\
\text { (Formations) }\end{array}$} & $\begin{array}{l}\text { BAMBUÍ GROUP } \\
\text { (Formations) }\end{array}$ & \multicolumn{2}{|c|}{$\begin{array}{l}\text { UMA GROUP } \\
\text { (Units) } \quad \text { (Form.) }\end{array}$} & $\begin{array}{l}\text { VAZA BARRIS/MIABA GR. } \\
\text { (Formations) }\end{array}$ \\
\hline \multirow{8}{*}{ 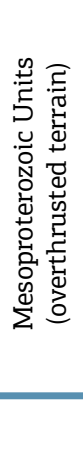 } & Serra da Lapa & Três Marias & & & - \\
\hline & Morro do Calcário & Serra da Saudade & & & - \\
\hline & Serra do Poço Verde & Lagoa do Jacaré & $\mathrm{A} 1$ & \multirow{6}{*}{ 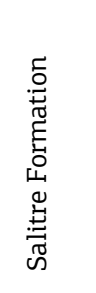 } & \multirow{2}{*}{ Olhos d’Água } \\
\hline & \multirow{2}{*}{ Serra da Garrote } & Serra de Santa Helena & A & & \\
\hline & & Sete Lagoas 3 & B1 & & Palestina \\
\hline & Lagamar & & & & Simão Dias Group \\
\hline & \multirow[b]{2}{*}{ Rocinha } & sete Lagoas $\angle$ & B & & \multirow{2}{*}{ Jacoca } \\
\hline & & Sete Lagoas 1 & C & & \\
\hline \multicolumn{2}{|c|}{ Santo Antônio do Bonito } & Jequitaí & \multicolumn{2}{|c|}{ Bebedouro } & Ribeirópolis \\
\hline
\end{tabular}

Figure 13. Correlation between the Vazante Group and Vaza Barris/Miaba groups (passive margin basins) and Bambuí, Una, Vazante, Miaba/Vaza Barris (intracratonic basins). Modifiedd from Misi et al. (2011). 
Despite these controversial ages, the isotopic record for ${ }^{87} \mathrm{Sr} /{ }^{86} \mathrm{Sr}$ in well-preserved carbonates from the intracratonic basins of the Bambui and Una groups (0.7074 to 0.7078 ), associated with remarkable negative and positive $\delta^{13} \mathrm{C}$ shifts, indicate possible sedimentation age between early Cryogenian and early Ediacaran (720 - 600 Ma) (Fig. 14; data plotted on Fig. 4 of Halverson et al. 2010). In this figure, data obtained in Otavi and Lufilian sequences in Africa are considered for correlations, in view of the reliable absolute geochronological data (from associated volcanic rocks) available (see Kaufman et al. 2009 and references therein). Lower ${ }^{87} \mathrm{Sr} /{ }^{86} \mathrm{Sr}$ ratios observed in cap carbonates of the Otavi Group and Lufilian Arc (0.7066) is probably due to differences in the tectonic and diagenetic evolution of Brazilian and African basins (Kaufman et al. 2009).

Kuchenbecker et al. (2016) stated that local inputs may control marine ${ }^{87} \mathrm{Sr} /{ }^{86} \mathrm{Sr}$ and not global processes, something which goes against the present knowledge of the Sr system. The high residence time of $\mathrm{Sr}$ in the ocean $(2.7 \mathrm{Ma})$ and the relatively high $\mathrm{Sr}$ concentration in seawater $(7.5 \mathrm{ppm})$ make a local control highly unlikely (see Jacobsen \& Kaufman
1999 and Veizer et al. 1999). In fact, the discrepancies that these authors correctly identified arise from a lack of reliable data for much of the Neoproterozoic, and thus a still poorly known global curve for that era. Furthermore, the different preparation methods for Sr isotopes may also contribute to this problem (see Melezhik et al. 2001).

Kuchenbecker et al. (2016) have mentioned that the Bambuí Basin may have been restricted, but did not mention occurrence of evaporite or extensive black shale deposits as further evidence. The occurrence of cosmopolitan fossils, such as Cloudina, militates against this restricted scenario.

\section{THE NEOPROTEROZOIC SURROUNDING BELTS}

\section{The Brasília Belt and Cratonic sedimentary cover}

The Brasília Belt is a Neoproterozoic orogen, formed along the western nargin of the São Francisco-Congo Craton.

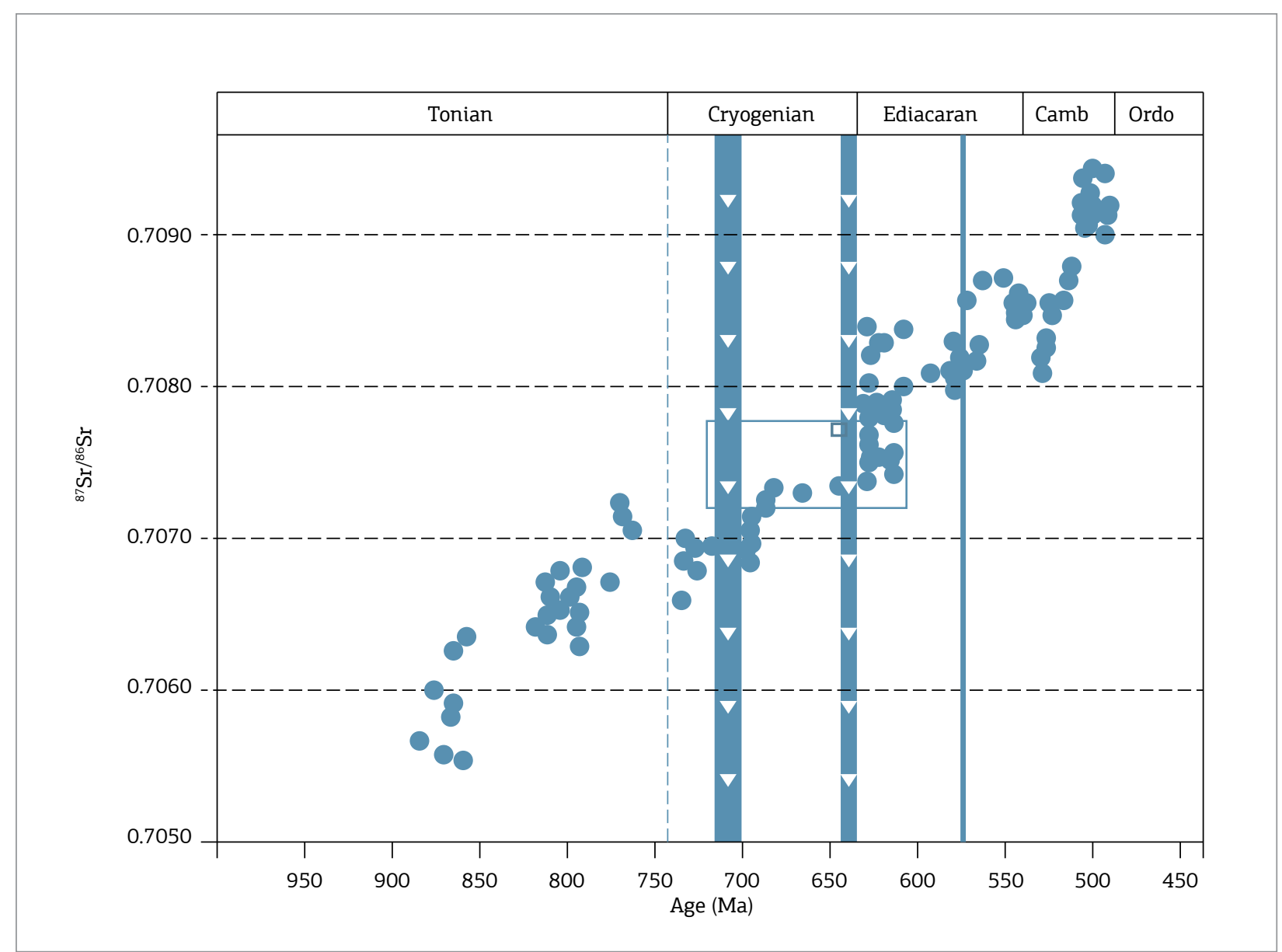

Figure $14 .{ }^{87} \mathrm{Sr} /{ }^{86} \mathrm{Sr}$ ratios for carbonates from the Bambuí and Una groups plotted against age on the Fig. 4 of Halverson et al. (2010). 
Most of the orogen is formed by sedimentary/metasedimentary units, with different tectonic significances and ages. For example, the Paranoá and Canastra groups most likely represent passive margin sequences, the Araxá Group is a fore-arc sequence, and the Bambuí Group which occupies the eastern part of the belt and also covers large areas of the craton, may represent a foreland sequence (Pimentel et al. 2011; Fig. 15). The Bambuí Group is represented by carbonate and siliciclastic sequence overlying glacial diamictes of the Jequitaí Formation of unknow age.

The depositional ages of these sequences are still controversial, mostly due to the apparent lack of volcanic layers, as well as the scarce content of diagnostic fossil associations. $\mathrm{Pb}-\mathrm{Pb}$ whole-rock data for basal carbonates of the Sete Lagoas Formation (base of the Bambuí Group) indicate the depositional age of ca. $740 \mathrm{Ma}$ (Babinski et al. 2007), suggesting

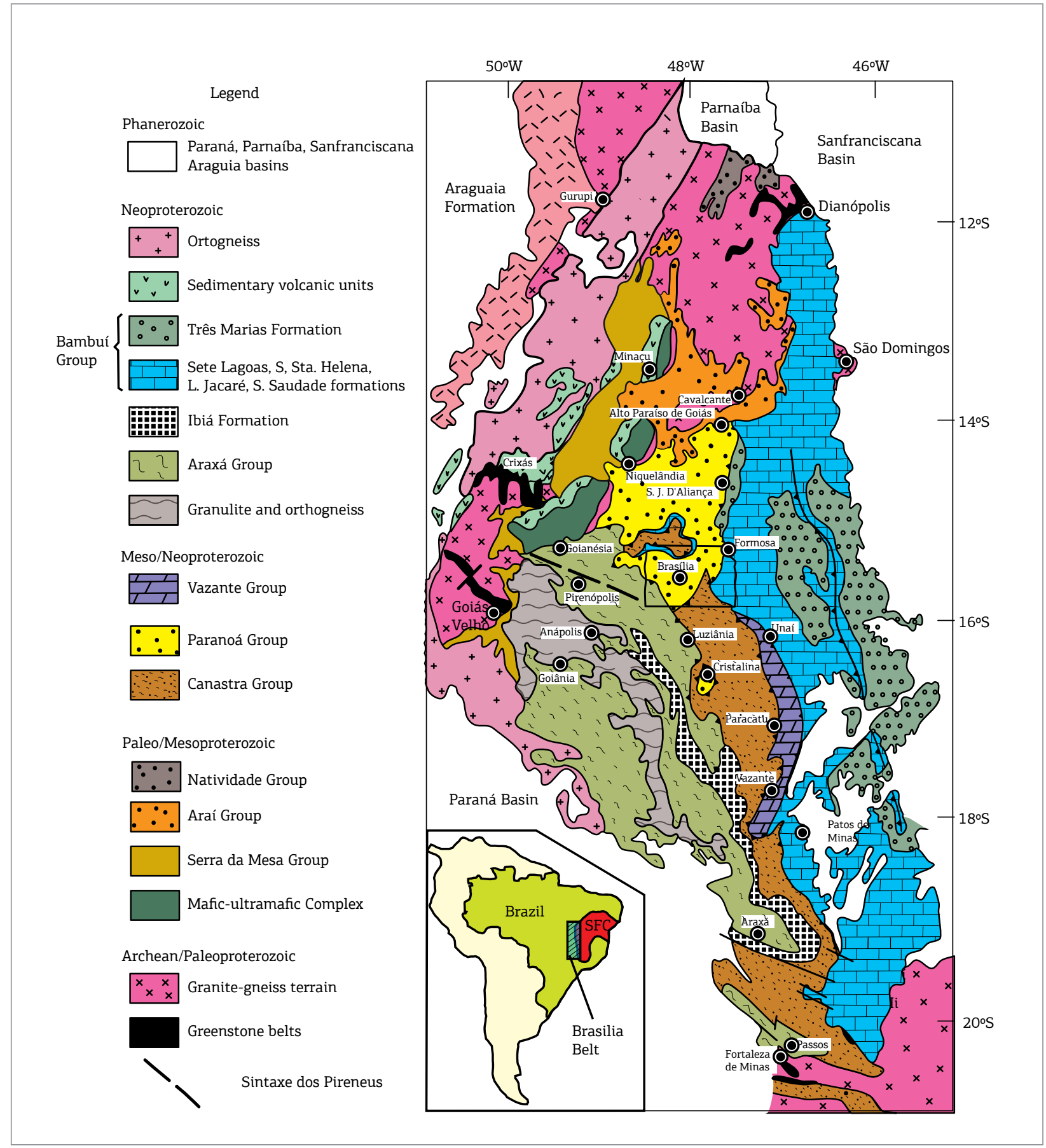

Figure 15. Simplified regional geological map of the Brasília Belt showing the distribution of the Vazante Group (after Marini et al. 1984, Dardenne 2000, Pimentel et al. 2000; Valeriano et al. 2004; modified from Misi et al. 2011). 
an early Cryogenian or late Tonian age (Shield-Zhou et al., 2016) for the Jequitaí diamictites which is compatible with $\mathrm{C}$ and $\mathrm{Sr}$ isotopic data for the cap carbonate. However, metapelites of the upper Sete Lagoas Formation, as well as the rest of the overlying formations of the Bambuí Group, contain zircon grains with important populations with ages of ca. $600 \mathrm{Ma}$, and even some of these metasediments have a few zircon grains as young as $550 \mathrm{Ma}$ (Pimentel et al. 2011, Paula Santos et al. 2014) suggesting an Ediacaran age for the unit. Recent paleontogical discoveries of Ediacaran fauna in the Sete Lagoas Formation indicate depositional age of ca. $550 \mathrm{Ma}$ (Warren et al. 2014), which agrees with the presence of the younger detrital zircon population. This recent data suggest, therefore, that part of the Sete Lagoas Group and the remaining overlying units have depositional ages close to the Precambrian-Cambrian boundary.

Carbonate rocks of the Paranoá and the Bambuí groups have been investigated for their $\mathrm{C}, \mathrm{O}$, and $\mathrm{Sr}$ isotopic compositions (Santos et al. 2000; Alvarenga et al. 2007, 2014). Santos et al. $(2000,2004)$ demonstrated that the isotopic patterns vary in the studied profiles, although a gereral positive excursion is oberved toward the upper parts of the Bambuí Group. These authors have shown in the investigated profiles (Sáo Domingos area) a sharp increase in the $\delta^{13} \mathrm{C}$ values at the very top of the Sete Lagoas Formation (+9 to $+12 \%$ ), a signal which is common to all profiles investigated, representing a regional stratigraphic marker (Santos et al. 2000). Carbonates of the underlying Paranoá Group have consistently lower $\delta^{13} \mathrm{C}$ values (normally close to $0 \%$ ).

Similarly, carbonates of the Paranoá and Bambuí groups are very different in terms of their ${ }^{87} \mathrm{Sr} /{ }^{86} \mathrm{Sr}$ ratio. Values between 0.7056 and 0.7068 are observed in upper carbonates of the Paranoá Group and higher values are recorded in Bambuí carbonates (0.7074 - 0.7080; Alvarenga et al. 2014). The $\mathrm{C}$ and $\mathrm{Sr}$ isotope stratigraphic data indicate very distinct characteristics for these two carbonate sequences. The data for the Paranoá carbonates are consistent with a Tonian sedimentation age, before the first Cryogenian glaciation. On the other hand, carbonate facies and isotope data for the Bambuí carbonates suggest deposition after the second Cryogenian glaciation.

As pointed out by Santos et al. (2000), the clear isotopic differences between the Paranoá and Bambuí groups indicate deposition in different paleoenvironments and different kinds of basin. According to these authors, based on the $\delta^{13} \mathrm{C}$ values, it may be postulated that the Paranoá Group sediments deposited on an open-marine platform (passive margin sequence?) whereas the Bambuí sequence formed in a restricted epicontinental sea affected by tectonic events of the Brasília Belt.This is compatible with the tectonic evolution suggested by Pimentel et al. (2011) based on provenance studies of the Brasília Belt. The common presence of Neoproterozoic zircon grains in the Bambuí Group is compatible with the erosion of adjacent Neoproterozoic mountanis, in a foreland setting.

\section{Rio Pardo Basin and Rio Preto Belt}

The Rio Pardo Basin is located in the southeastern border of the São Francisco craton, between São João do Panelinha and Itapebi villages in Bahia, eastern Brazil (Fig. 16). This basin is divided into two sub-basins, separated by a reverse fault: the southwestern sub-basin was involved in the folding of the Araçuaí Belt; sedimentary rocks of the northeastern sub-basin have been deposited on the foreland of this belt on the São Francisco Craton.

The Rio Pardo Group comprehends, from base to top, the following litho-stratigraphic units (Pedreira 1999; Sial et al. 2009):

1. Panelinha Formation underlies the other formations of this Group and consists of conglomerate, breccia, greywacke, and arkose. Diamictites with clasts of granulite and volcanics are, perhaps, glacial in origin;

2. Itaimbé sub-group that encompasses the intermediate formations of the Rio Pardo Group, from north to south:

1. Camacan Formation (pelite, siltite and carbonate rocks);

2. Água Preta Formation (phylite, sandstone, siltite, slate and carbonate rocks;

3. Serra do Paraíso Formation (carbonate rocks locally with stromatolites, and quartzite);

4. Santa Maria Eterna Formation (quartzite, conglomerate and carbonatic intercalations with tepee structures;

5. finally, turbidites of the Salobro Formation overly discordantly the Camacan Formation and are in tectonic contact with the Água Preta Formation (greywacke, siltite, sandstone, and conglomerate); and

3. Salobro Formation (polymitic conglomerate, greywacke and sandstone). Sedimentary rocks of the Rio Pardo Group have been metamorphosed in the greenschist facies.

Carbonate rocks of the Serra do Paraíso Formation (Rio Pardo Basin) are seen in sharp contact with diamictite/arkose of the São João do Panelinha Formation and same situation with respect to carbonate rocks of the São Desidério Formation (Rio Preto Belt) in relation to the Canabravinha diamictite. It is possible that cap carbonates are present in both cases.

Carbon-isotope stratigraphy of the Serra do Paraíso and Sáo Desidério formations could be useful tool to demonstrate this hypothesis. Only a preliminary C-isotope survey was done on carbonates of the Rio Pardo Basin but the lack of clear stratigraphic control on the analyzed samples preclude further stratigraphic interpretation (Costa 
Pinto 1977). C and O isotopes have been analyzed in a total of 173 carbonate samples from the Paraíso and São Desidério formations (Cezario et al. 2011) aiming at a high-resolution isotope stratigraphy and elucidating the paleoclimatic issue. At the eastern portion of the Água Branca Range, a section $(17 \mathrm{~m})$ on buff dolostone, they found $\delta^{13} \mathrm{C}$ values around $-2 \%$. At the western side of the Agua Branca Range, a section (12 m) of gray limestones in a folded sequence of rhythmites exhibit $\delta^{13} \mathrm{C}$ values from +3.5 to $+6 \%$ and a section to the north of Pau Brasil village $(12 \mathrm{~m})$ shows values from +7 to $+9 \%$. A composite C-isotope section is found in Figure 17 and the $\delta^{13} \mathrm{C}$ pathway resembles that observed in successions with basal cap carbonates.

The Rio Preto Belt is located at the northwestern border of the São Francisco Craton (Fig. 18) as an example of an intracontinental belt (Egydio-Silva 1987; Egydio-Silva et al. 1989; Andrade Filho et al. 1994; Trompette 1994; Sial et al.
2009) and is considered a marginal belt forming an extension, to the west, of the Riacho do Pontal and Sergipano belts. These sedimentary successions are an equivalent to those of the São Francisco Supergroup in Bahia. From south to north, the Rio Preto Belt can be subdivided into three structural units:

1. southern unit, region of São Desidério, the sequence begins with limestone with argillaceous intercalations (50 m thick, horizontal layers) and shows no sign of metamorphism or deformation (cratonic domain). This unit was called São Desidério Formation (Egydio-Silva et al. 1989) probably equivalent to the Sete Lagoas Formation of the Bambuí Group, Minas Gerais;

2. to the north, inwards the belt, limestones are overlain by clastic rocks that show intercalations of marls and limestones (Serra da Mamona Formation), a sequence probably correlated with the Santa Helena Formation (Egydio-Silva et al. 1989);

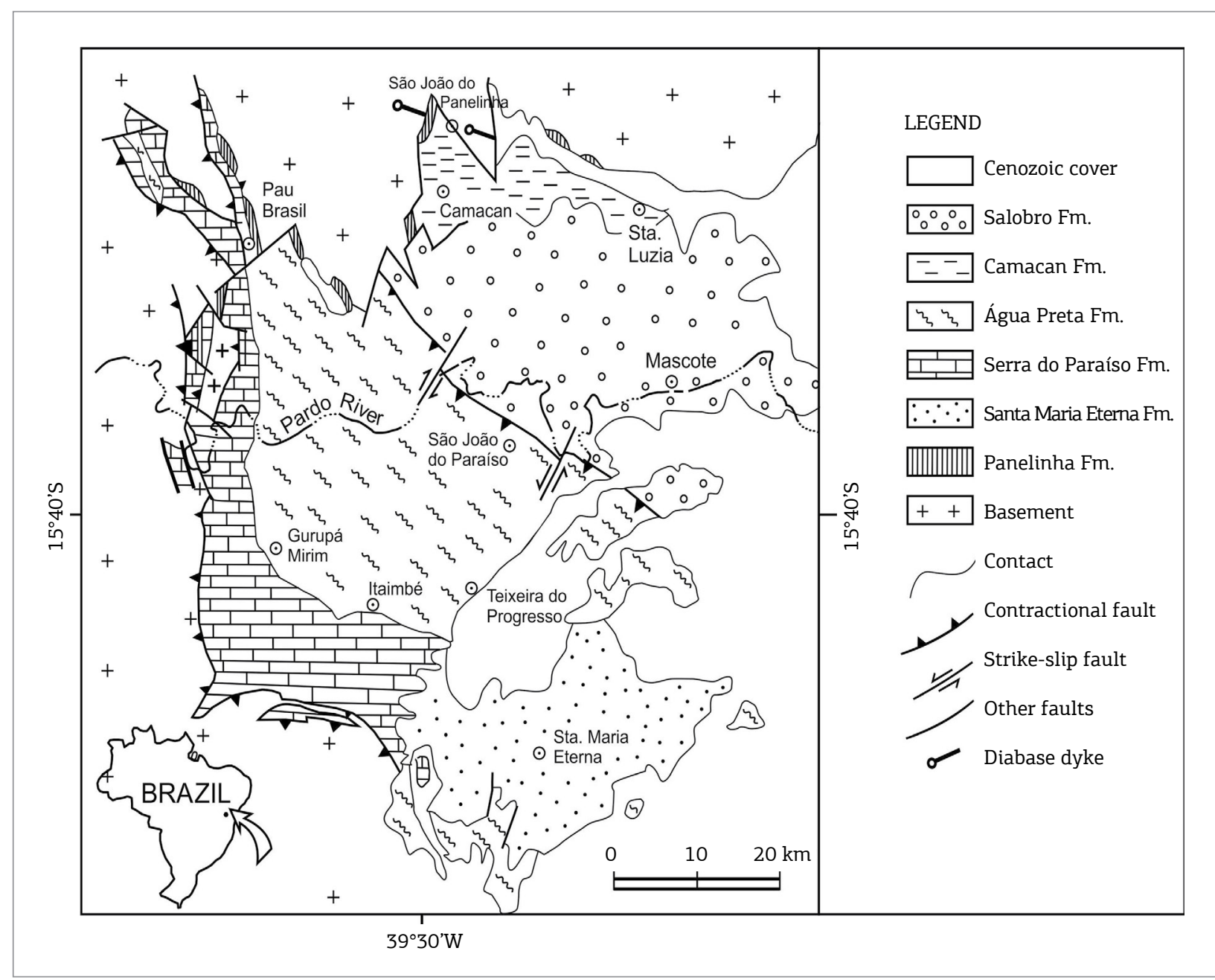

Figure 16. Simplified geological map of the Rio Pardo Basin, eastern São Francisco Craton (modified from Pedreira 1999; Sial et al. 2010). 

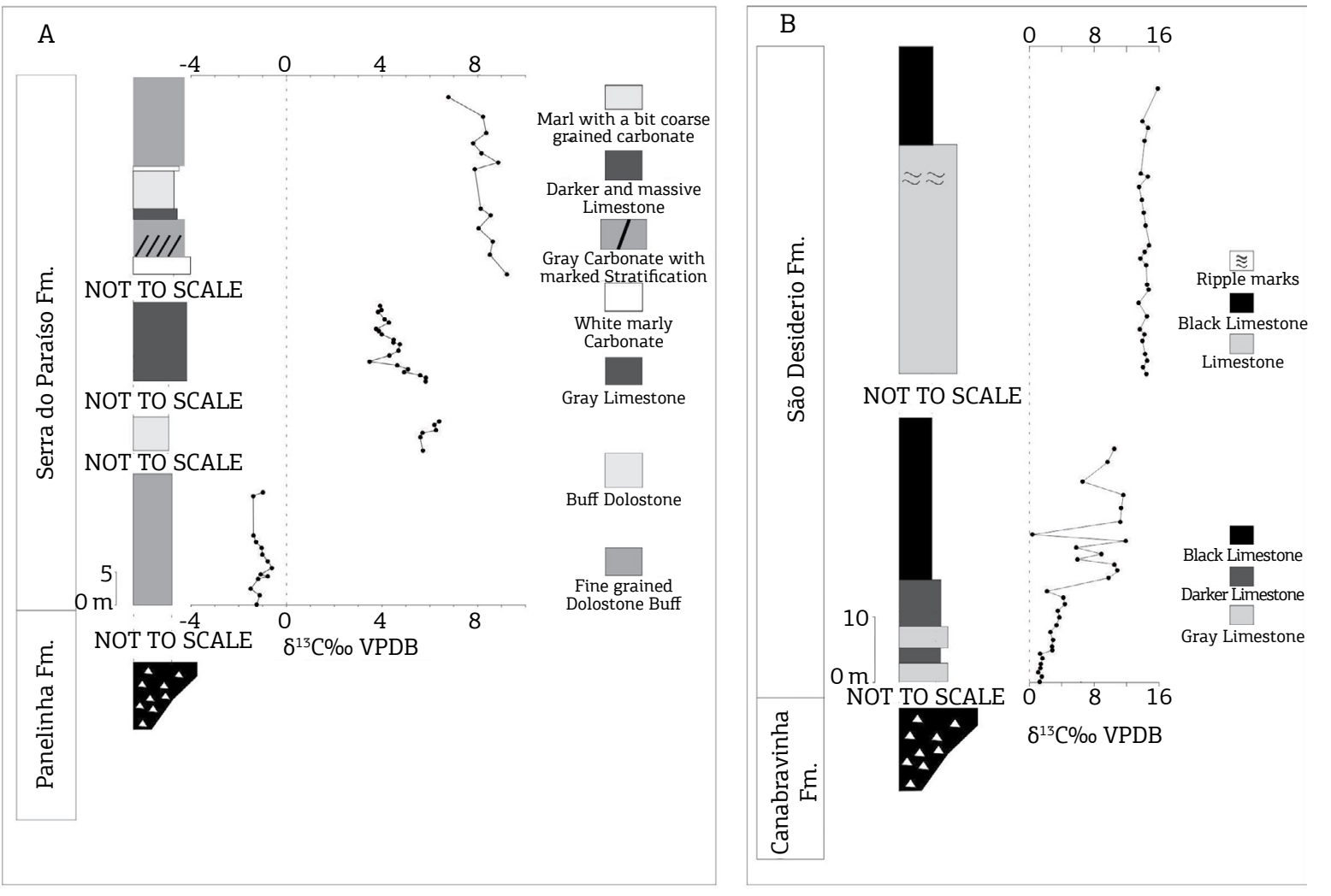

Figure 17. C- and O-isotope chemostratigraphy for sucessions at the Rio Pardo Basin (A) and Rio Preto Belt (B).

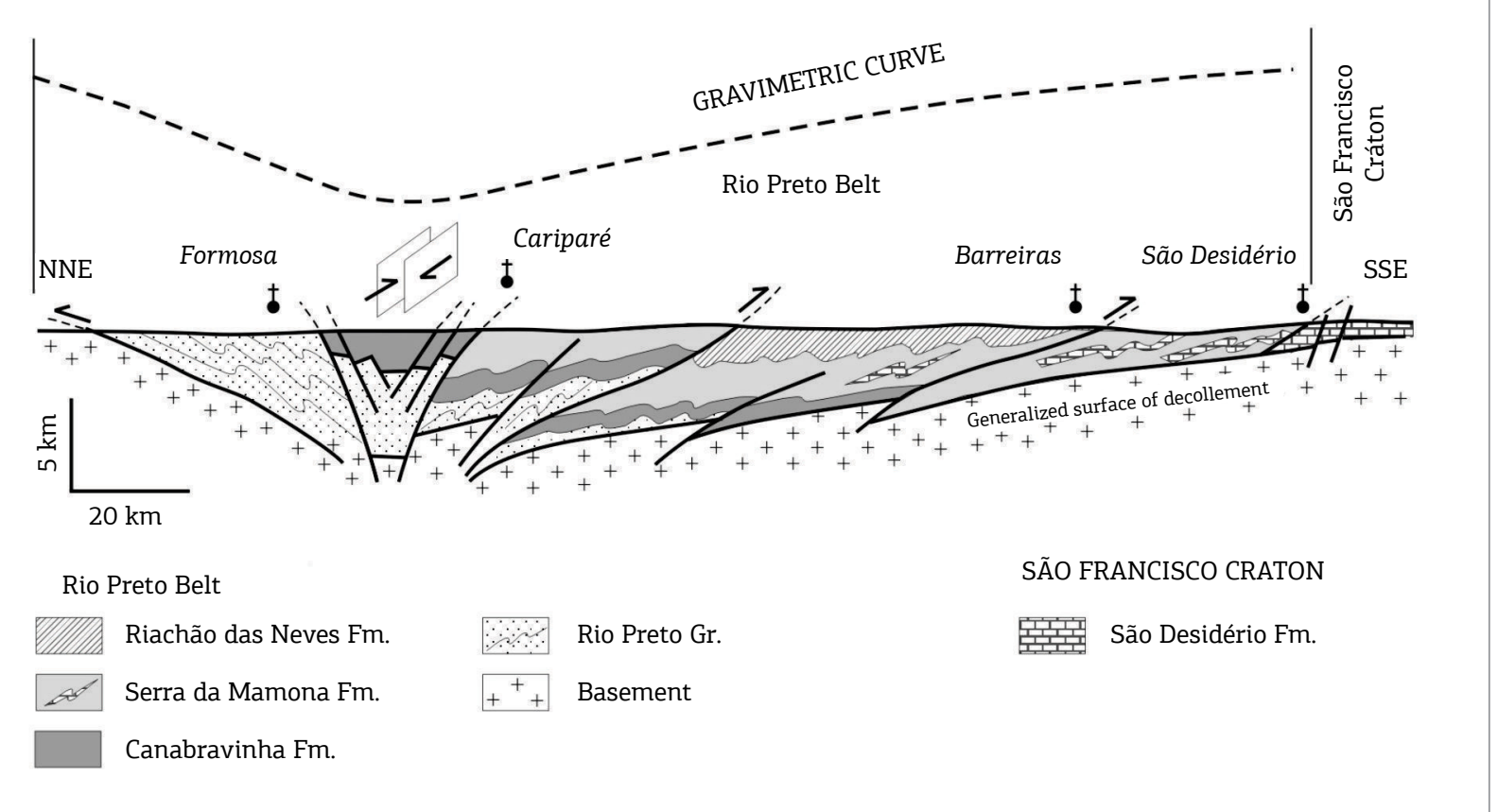

Figure 18. Cross-section for the Rio Preto belt (Egydio-Silva, 1987; Sial et al. 2010). 
3. north of Barreiras village, limestones are overlain by arkoses, quartzites (locally feldspathic), graywackes, and rare carbonate intercalations (Riachão das Neves Formation). This sequence is considered partially equivalent to the Três Marias Formation of the Bambuí Group (Trompette 1994).

In the central portion of the belt, the Canabravinha Formation is represented by diamictites with pebbles, cobbles, and boulders of gneiss, quartzite, siltstone, marble, and schist. This unit has been correlated to the Jequitaí/ Bebedouro Formation, probably deposited in a glacial marine environment.

In the Rio Preto Belt, continuous chemostratigraphic sections of representative successions of the São Desidério Formation (Cezario et al. 2011) were made at:

1. Derocal locality about $20 \mathrm{~km}$ from São Desidério;

2. the Mineração do Oeste Quarry at São Desidério village;

3. Sítio Rio Grande about $50 \mathrm{~km}$ from São Desidério; and

4. Penedo Quarry.

At the Derocal locality, reddish dolomitic argillites display $\delta^{13} \mathrm{C}$ values from +2.5 to $+5 \%$, whereas at the Mineração do Oeste Quarry, limestones yielded $\delta^{13} \mathrm{C}$ values from +1.2 to $+2.2 \%$ in the first $16 \mathrm{~m}$ (base to top) changing abruptly up section to values in the +10 to $+12 \%$ range in dark, organic matter-rich limestone. At the Sítio Rio Grande locality, $45 \mathrm{~m}$ of limestones were sampled and $\delta^{13} \mathrm{C}$ values vary from +13.5 to $+15 \%$ o in the first $30 \mathrm{~m}$ (base to top) and from +14 to $+16 \%$ in the upper $15 \mathrm{~m}$, organic matter-rich dark limestone. No negative $\delta^{13} \mathrm{C}$ value has been recorded in these $\delta^{13} \mathrm{C}$ profiles and a composite $\delta^{13} \mathrm{C}$ pathway is shown in Fig. 17. The C-isotope stratigraphy of the São Desidério Formation approaches that of the top of the Sete Lagoas and Lagoa do Jacaré formations described elsewhere by Santos et al. (2000).

\section{Sergipano Belt}

The Sergipano Belt is a fold-and-thrust belt located in the northeastern margin of the São Francisco Craton (Fig. 19) that was formed by the continental collision between the Congo-São Francisco Craton and the Pernambuco-Alagoas Massif during the Brasiliano/Pan-African orogeny (Brito Neves et al. 1977). It has been interpreted as a geosyncline (Humphrey \& Allard, 1968; Silva Filho \& Brito Neves 1979) and later as a collage of lithostratigraphic domains (Davison \& Santos 1989; Silva Filho 1998) or as a Neoproterozoic belt produced by inversion of a passive margin basin located at the northeastern margin of the São Francisco plate (DelRey Silva 1999).

This belt consists, from north to south, of six lithostratigraphic domains separated from each other by major shear zones: Canindé, Poço Redondo, Marancó, Macururé, Vaza Barris, and Estância (Santos \& Souza 1988; Davison \& Santos 1989; Silva Filho 1998). The Macururé, Vaza Barris, and Estância domains are composed mostly of metasedimentary rocks with metamorphic grade from incipient (or non-metamorphic in the Estância Domain) through greenschist grade, in the Vaza Barris, to amphibolite facies, in the Macururé Domain. Silva Filho \& Torres (2002) and Silva Filho et al. (2003) have proposed three additional domains: Rio Coruripe, Viçosa, and Pernambuco-Alagoas. Further geological details on all domains of the Sergipano Belt are found in Davison \& Santos (1989) and Santos et al. (1998).

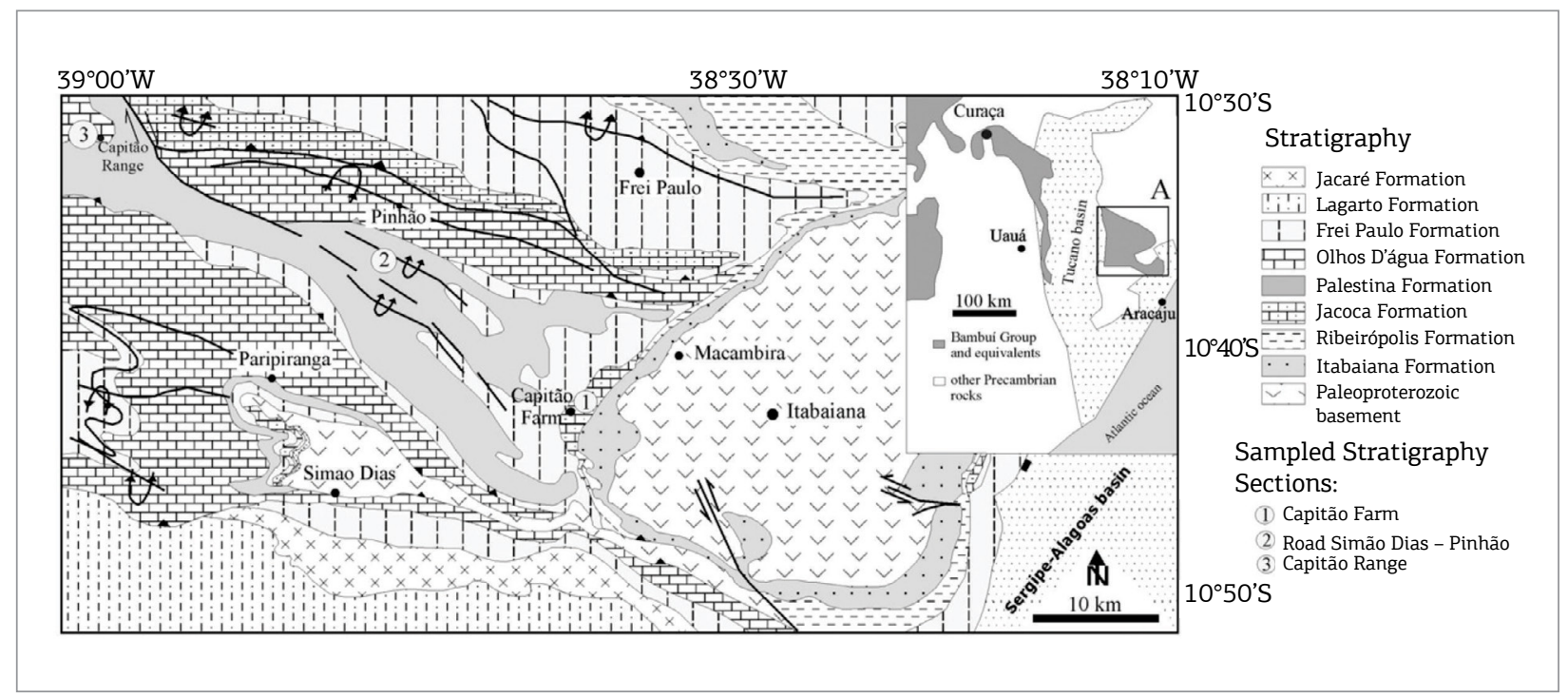

Figure 19. Simplified geological map of the eastern Vaza Barris Domain, Sergipano Belt (modified from D'el Rey Silva, 1999; Sial et al. 2010), with the indication of sampled stratigraphic sections in Sial et al. (2010). 
The Juetê-Acauã, Ribeirópolis-Jacoca, and Palestina Olhos D'Água Formation diamictite-carbonate couplets in the Vaza Barris and Estância domains have been regarded as Neoproterozoic cap carbonates (Sial et al. 2000, 2006, 2010). Their relative chronology and correlation with similar cap carbonates in southwestern Gondwana was constrained using carbon- and strontium-isotope chemostratigraphy (Sial et al. 2010). Additionaly, a preliminary discussion on the use of $\mathrm{Hg}$ chemostratigraphy as a potential proxy for volcanism in the study of post-glacial cap carbonates was presented.

Stratigraphic studies on the Vaza Barris and Estancia domains of the Sergipano Belt were pioneered by Humphrey \& Allard $(1968,1969)$ who divided the supracrustal sequences into two groups, Miaba and Vaza Barris, a stratigraphic scheme that was later modified by Silva Filho \& Brito Neves (1979) and D'el-Rey Silva (1995, 1999). Among the most relevant modifications, D'el-Rey Silva $(1995,1999)$ proposed that the Ribeiropolis Formation is older than formerly believed, placing it below the Jacoca Formation. It is assumed here that the Frei Paulo Formation sits on top of the Olhos D'Água Formation as accepted by most authors (Humphrey \& Allard 1969; Silva Filho \& Brito Neves 1979; Davison \& Santos 1989).

The Estancia Group, northern Bahia, comprises the Juetê, Acauã, and Lagarto formations (Silva Filho \& Brito Neves 1979). These authors hypothesized that the Juetê and Ribeiropolis formations could be chrono-correlate as well as the Acauã and Jacoca formations, a contention that needs further confirmation.

Two depositional cycles both being represented by a basal continental to shallow-marine siliciclastic megasequence, overlain by a carbonate sequence have been recognized by D'el Rey-Silva (1995, 1999). These two cycles, with slight modifications, are:

1. Cycle I (Estância-Miaba Group) with a siliciclasticmegasequence including the Itabaiana (conglomerate, quartzite, metasiltite), Juetê (sandstone, diamictite), Ribeirópolis (silty phyllite, metagreywacke, pebbly phyllite, diamictite) formations, and a carbonate sequence, represented by the Jacoca Formation, stratigraphically equivalent to the Acaua Formation;

2. Cycle II with an upper siliciclastic megasequence (LagartoPalmares and Jacaré formations of the Simão Dias Group) overlain by the Vaza Barris Group that comprises diamictites of the Palestina Formation, an upper carbonate megasequence (Olhos D’Água Formation) and the Frei Paulo Formation (pelite and siltstone with rare carbonate rocks). These two megasequences underwent subgreenschistfacies metamorphism which has preserved original sedimentary structures.
The Estância-Miaba Group is well exposed around the Itabaiana and Simáo Dias basement domes in Sergipe. The Ribeiropolis Formation is $0-300 \mathrm{~m}$ thick around this dome and locally reaches thicknesses of about $500 \mathrm{~m}$ within the belt. It consists of diamictite, metagreywacke, and quartz-sericite phyllite transitionally overlying quartzite of the Itabaiana Formation. The occurrence of volcanic rocks in this formation, in the west side of the Simão Dias dome, has been reported by D'el-Rey Silva (1995, 1999). Carbonates of the Jacoca Formation are seen in sharp contact on top of the Ribeiropolis diamictite at the Capitão Farm along the Salgado River (western side of the Itabaiana dome). A typical section of the Jacoca Formation starts with a thick layer of laminated gray-to-pink dolostone containing pyrite and chalcopyrite. This is followed upsection by a 3- to 15-m-thick layer of laminated dolostone, and dark gray to black phyllites and about 10 -m-thick bed of massive dolostone. This unit is overlain by a 40 -m-thick heterolithic sequence of gray limestone and dark-to-dark phyllite and finally by gray dolostone.

At the Capitâo Farm, the cap dolostone shows wavy lower contact. Clasts at the top of the diamictite of the Ribeiropolis Formation are concentrated and salient as a result, perhaps, of lithification and erosion prior to cap dolostone deposition. Features suggesting soft sediment deformation were observed in the diamictites and cap carbonates, which may be interpreted as the result of a rapid icehouse to greenhouse transition (e.g. Puga cap carbonate, Amazon Craton; Nogueira et al. 2003). Well-developed tubestone stromatolites occur at the dolostone cap carbonate in the Capitão Farm (Sial et al. 2010b).

Carbonate rocks of the Acauã Formation overlie either the Juetê diamictite or rest unconformably on basement gneiss. Well-preserved exposures of this contact occur in the western Vaza Barris Domain, between Euclides da Cunha and Bendegó villages, at Patamuté village and at the Serra da Borracha and at Serra da Canabrava (northeastern Bahia). The type locality of the Juetê Formation is at the Juetê River, about $6 \mathrm{~km}$ south of Bendegó, where it shows total thickness of about $30 \mathrm{~m}$ and is composed of buff sandstone, diamictite (about $15 \mathrm{~m}$ thick), and reddish feldspathic sandstone and reddish claystone (Silva Filho \& Brito Neves 1979).

The Acauã Formation consists of cap dolostone, limestone (with dolostone dropstones) in proximal sections as seen at the Borracha Range, $20 \mathrm{~km}$ west of Patamuté, Bahia, and limestone/dolostone and limestone-shale rhythmites. Continuous sections of the Acaua Formation are exposed at Serra da Borracha and at Serra da Canabrava, as well as Patamuté Creek at Patamuté village and São Gonçalo Farm, about $25 \mathrm{~km}$ to the north of Euclides da Cunha village, Bahia (Sial et al. 2010b). 
Dolostones of the Acauã Formation conformably overlie diamictites of the Juetê Formation, the former showing hummocky and, locally, pseudo-tepee structures. Up section, they pass into a fining and thinning-upward carbonate succession. Diamictites of the Juetê Formation contain clasts of granite, orthogneiss, phyllite, or quartz composition up to $0.5 \mathrm{~m}$ in diameter, and locally display Fe-rich claystone beds.

The Olhos D'Agua Formation $(200-1300 \mathrm{~m}$ ) is composed of interbedded limestones (organic-rich toward the top) and green, calcareous chlorite-schists, and siltyphyllites. It overlies diamictites and pebbly metagreywackes of the Palestina Formation. Marble beds are interbedded with blue to black, fine-grained metalimestone and gray metadolostone. The thick carbonates around the Simão Dias dome pass upward into supratidal-intertidal facies with oolites and wave-reworked sedimentary structures indicating a near-shore environment (D’el-Rey Silva 1995). At the Capitão Range, about $25 \mathrm{~km}$ northwest of Paripiranga, Bahia, a 10-m-thick dolostone layer of the Olhos D'Agua Formation is in sharp contact with diamictite of the Palestina Formation (metagreywacke with clasts up to $30 \mathrm{~cm}$ in diameter) and followed up section by about $50 \mathrm{~m}$ of limestone-pelite intercalations. They are in turn overlain by laminated limestone ( $40 \mathrm{~m}$ thick) culminating with a 30-m-thick layer of organic-rich black.

The current geochronological data indicate that the deposition of Jacoca Formation carbonates is younger than $780 \mathrm{Ma}$ and the deposition of the Olhos D'Agua Formation carbonates took place took place after $653 \mathrm{Ma}$ and before $628 \mathrm{Ma}$ (Sial et al. 2010).

Detrital zircons from the diamictite of the Juetê Formation, to the north of Euclides da Cunha, are older than $2073 \mathrm{Ma}$ (Oliveira et al. 2008) and detrital zircons from sandstones of the Lagarto (on top of the Acauã Formation) and Palmares Formations display ages that cluster around $565 \mathrm{Ma}, 582$, $633 \mathrm{Ma}, 956 \mathrm{Ma}, 977 \mathrm{Ma}$, and $1855 \mathrm{Ma}$.

The sections chemostratigraphically investigated in the Sergipano Belt by Sial et al. (2010) show well-preserved cap carbonates in knife-sharp contact with basal diamictites as known for Neoproterozoic cap carbonates worldwide (e.g. Kennedy 1996; Hoffman \& Schrag 2002). Several localities in the eastern and western Vaza Barris Domain fulfill this requirement. Among them, Sial et al. (2010) have stratigraphically sampled carbonates of the Jacoca Formation in sharp contact with diamictites of the Ribeiropolis Formation at Capitão Farm. The Acauã Formation overlies with sharp contact diamictites of the Juetê Formation at the Borracha Range, at the Patamuté Creek in the Patamuté village as well as at São Gonçalo Farm in the state of Bahia. Besides, carbonates of the Olhos D'Agua Formation in sharp contact with diamictites of the Palestina Formation at the Capitão Range were also sampled.
Several other localities in Sergipe and Bahia offer exposures of carbonate rocks of the Jacoca, Acauã, and Olhos D’Água. Among them, well-preserved carbonate exposures of the Acauã Formation at the Serra da Canabrava and at the Almeida Farm near the Serra da Borracha, and along the road between Euclides da Cunha and Bendengó (Bahia) have been sampled by Sial et al. (2010). Besides, continuous outcrops of the Olhos D'Agua Formation in the road Rosario-Cocorobó, Bahia, and south of Pinhão village, Sergipe, have been also sampled.

In the eastern Vaza Barris Domain, carbonates of the Jacoca Formation at the Capitáo Farm show negative $\delta^{13} \mathrm{C}$ values, mostly between -5 and $-4 \%$ while $\delta^{18} \mathrm{O}$ values are mostly around -8\% VPDB (Fig. 20). Shallow-marine dolostones of this formation display increasing $\delta^{13} \mathrm{C}$ values, from -6.2 to $-4.3 \%$ o, interrupted by a sudden decrease to values of $-6.7 \%$ at the base of the overlying deep shelf limestone succession. Such values shift back to values as high as $-1.5 \%$ o VPDB in its uppermost portion. The cap dolostones of this formation show relatively limited thickness (a couple of meters or less, especially in more distal sections).

In the western Vaza Barris Domain, detailed C and O isotope chemostratigraphy for the Acauá Formation (São Gonçalo Farm, Borracha and Canabrava Ranges, Patamuté and road Euclides da Cunha-Bendengó) revealed that $\delta^{13} \mathrm{C}$ values tend to group mostly between -5 and $-4 \%$, within the range for mantle values (Hoffman \& Schrag 2002). This highlights the role of mantle-derived $\mathrm{CO}_{2}$ in carbonate deposition in the aftermath of the glacial event represented by diamictites of the Juetê Formation.

At Serra da Borracha hill, $\delta^{13} \mathrm{C}$ values are kept very homogeneous ( - -5\%o) for about $165 \mathrm{~m}$. Only about $1 \mathrm{~m}$ of shallow marine dolostone is present in the base of the profile (part of the cap dolostones has been eroded away) being followed up section by $30 \mathrm{~m}$ of gray fine-grained limestones with dolostones dropstones and limestone-dolostone rhythmites. $\delta^{18} \mathrm{O}$ values for this interval vary gradually from about -12 to about $-5 \%$ VPDB. Such enormous fractionation, if primary, likely resulted from a gradual temperature decrease by the time dolostone-dropstones were deposited. Up section, an interval characterized by boudinaged dolostone-limestone intercalations with plane-parallel lamination is observed indicating below wave-base deposition.

Carbonates at Serra da Canabrava Range show $\delta^{13} \mathrm{C}$ values from -6 to $-0.2 \%$ and a package of light gray fine-grained limestones near the Almeida locality, nearby Canabrava Range, exhibits values from -0.5 to $+0.3 \%$ and seem to be stratigraphically above the carbonate succession at Serra da Borracha. The nearly identical behavior of $\delta^{13} \mathrm{C}$ in the Acauá and Jacoca carbonates opens the possibility that they could have been simultaneously deposited, a contention that finds no support in the $\mathrm{Sr}$ isotope behavior as discussed later on. 
Marly and dolomitic carbonates of the Olhos D'Agua Formation overlying diamictites of the Palestina Formation, near the road Simão Dias-Pinhão (Sergipe), display $\delta^{13} \mathrm{C}$ values as low as $-4.7 \%$, increasing upsection to a plateau between 0 and $1 \%$ and finally to another plateau around +8 to $+10 \%$ o. This pattern is observed in the sections at the Capitão Range, at the section in the Rosario-Cocorobó road (Bahia) and between Simão Dias and Pinhão villages (Sergipe). The $\delta^{18} \mathrm{O}$ values in these sections vary from -7 to $-11 \%$ VPDB and $\delta^{13} \mathrm{C}$, from -5 to $+9 \%$ and seem to be

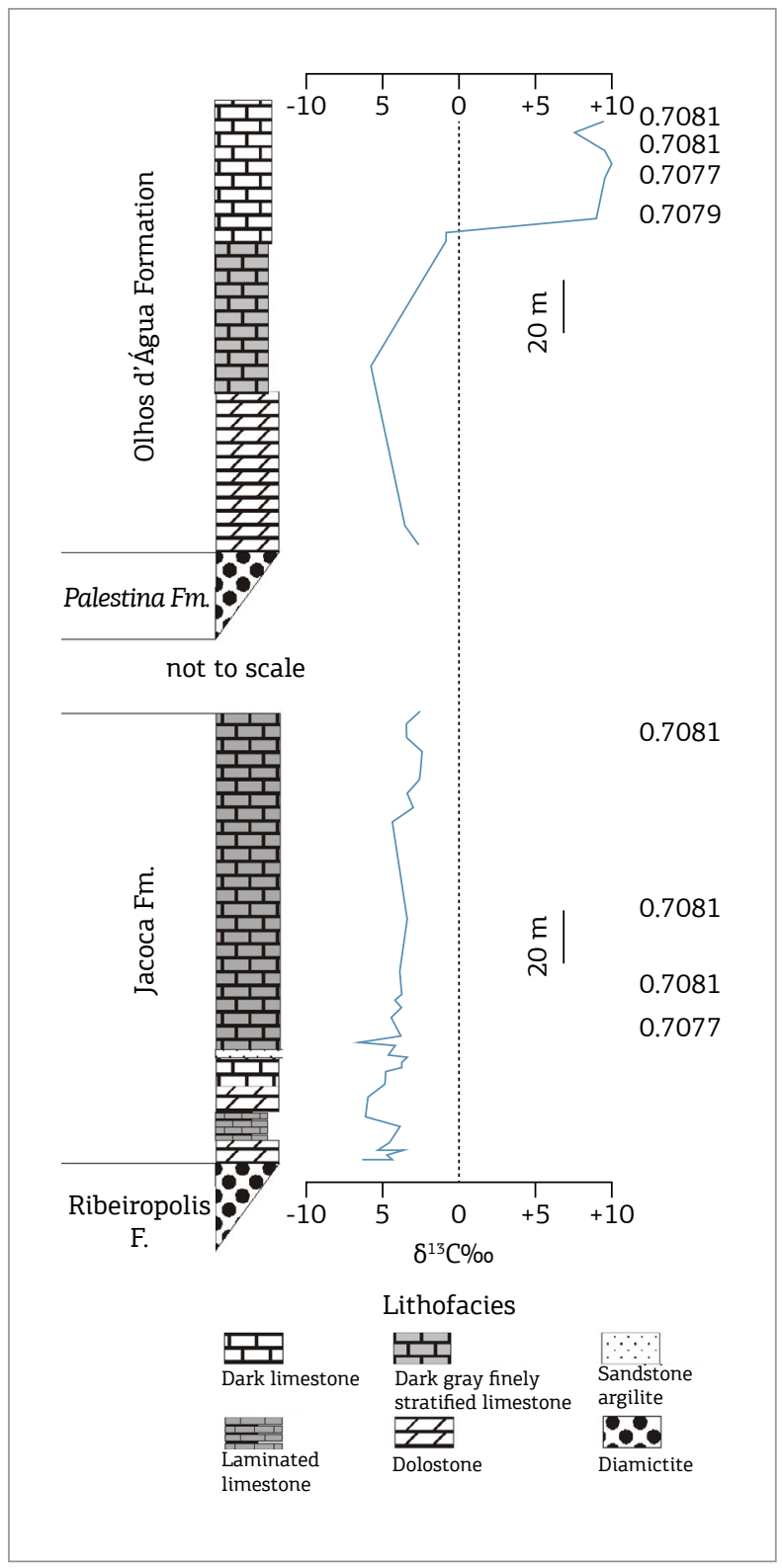

Figure 20. Litho- and composite $\delta^{13} \mathrm{C}$ curve and ${ }^{87} \mathrm{Sr} /{ }^{86} \mathrm{Sr}$ ratios for carbonates of the Jacoca (Estância-Miaba Group) and Olhos D'Agua formations (Vaza Barris Group). The variation of $\mathrm{Sr}$ isotopes also shown in this composite section (modified from Sial et al. 2010). primary regarding the low $\mathrm{Mn} / \mathrm{Sr}$ and lack of co-variance between $\delta^{13} \mathrm{C}$ and $\mathrm{Mn} / \mathrm{Sr}$ values (Fig. 20).

A section of the Olhos D'Água Formation near Rosário village, Bahia, shows an intercalation of limestones and siltstones, where the carbonate lenses show variable thickness. These carbonates have been deposited on top of diamictites of the Palestina Formation, the latter comprising pebbles, boulders, and blocks of granite, gneiss, black phyllite, black silexite, greenish quartz, and gray limestones. The $\delta^{13} \mathrm{C}$ values start with slightly negative values $(--2 \%)$ and about $10 \mathrm{~m}$ from the base, values change dramatically and form a well-defined plateau around $+9 \%$, while the $\delta^{18} \mathrm{O}$ values vary from -10 to $-12 \%$ VPDB.

Strontium isotope ratios have been analyzed in forty carbonate samples from the Sergipano Belt including samples from the Acauã Formation (Borracha, Patamuté, São Gonçalo, Euclides da Cunha) and Olhos D'Agua Formation (Rosario and Capitão Hill) in the western Vaza Barris Domain and Jacoca Formation (Capitáo Farm) and OlhosD'Agua Formation (road Simão Dias-Pinhão) in the eastern Vaza Barris Domain. Typically, carbonate samples with high $\mathrm{Sr}$ (> $600 \mathrm{ppm}$ ), low $\mathrm{Rb}(<10 \mathrm{ppm})$, low $\mathrm{Mn} / \mathrm{Sr}(<10)$, and low $\mathrm{Mg} / \mathrm{Ca}(<0.2)$ ratios have been considered for $\mathrm{Sr}$ isotope-ratio analysis since usually samples which meet these requirements yield consistent ${ }^{87} \mathrm{Sr} /{ }^{86} \mathrm{Sr} \mathrm{Sr}$ ratios. However, when dolomite was the only carbonate present $(\mathrm{Mg} / \mathrm{Ca}$ around 0.6$)$, consistency of the ${ }^{87} \mathrm{Sr} /{ }^{86} \mathrm{Sr}$ ratios was the only selection criterion.

Carbonates of the Jacoca Formation have ${ }^{87} \mathrm{Sr} /{ }^{86} \mathrm{Sr}$ ratio values of $0.7077,0.7081$, and 0.7081 at Capitão Farm. Four analyses of carbonates of the Acauã Formation yielded consistent results at the Borracha Range (two values of 0.7072 and two, 0.7073 ) but very variable and higher values at the three other localities examined in the western Vaza Barris Domain (all dolostones). Three ${ }^{87} \mathrm{Sr} /{ }^{86} \mathrm{Sr}$ ratios for high-Sr carbonates of the Olhos D'Agua Formation in the section near Pinhão village yielded values of $0.7078,0.7080$, and 0.7080. At Capitão Range, carbonates of this Formation have values of $0.7077-0.7081$ and from 0.7077 to 0.7082 at the section near Rosario Village. All these ${ }^{87} \mathrm{Sr} /{ }^{86} \mathrm{Sr}$ ratios are within the typical range for late Neoproterozoic seawater (Kaufman et al. 1993, 2009).

Therefore, carbonates of the Olhos D'Agua Formation from the three localities examined (eastern and western Vaza Barris domains) show nearly the same range of ${ }^{87} \mathrm{Sr} /{ }^{86} \mathrm{Sr}$ ratios, indistinguishable from that of the Jacoca Formation at the Capitão Farm. However, ${ }^{87} \mathrm{Sr} /{ }^{86} \mathrm{Sr}$ ratios for the Borracha Range are consistently lower than those for the Jacoca Formation, in contrast with $\delta^{13} \mathrm{C}$ values (all negative) that tend to fall in the same range for these two Formations.

Correlation of some Cryogenian and Ediacaran successions in Brazil and Africa, based on lower radiogenic 
${ }^{87} \mathrm{Sr} /{ }^{86} \mathrm{Sr}$ ratios (best preserved samples), are summarized in Table 1. Kaufman et al. (2009) have compiled ${ }^{87} \mathrm{Sr} /{ }^{86} \mathrm{Sr}$ ratios for limestones in cap carbonates across southwestern Gondwana and they seem to fall consistently within three modes with values near $0.7066,0.7073$, and 0.7081 represented, respectively, by the Rasthof, Maieberg, and Bildah cap carbonates in Namibia and their temporal equivalents. In this scheme of Kaufman et al. (2009), ${ }^{87} \mathrm{Sr} /{ }^{86} \mathrm{Sr}$ ratios for the Acauã Formation carbonates at the Borracha Range (0.7073) approach ${ }^{87} \mathrm{Sr} /{ }^{86} \mathrm{Sr}$ ratios for Sturtian II cap carbonates deposited between 740 and $635 \mathrm{Ma}$. In addition, similarly to the Maiberg cap carbonate, $\delta^{13} \mathrm{C}$ values at the Borracha Range are all negative. However, ${ }^{87} \mathrm{Sr} /{ }^{86} \mathrm{Sr}$ ratios as low as 0.7073 have been reported from Ediacaran, Cloudinabearing limestones in Uruguay (Gaucher et al. 2004, 2009) and are also similar to ${ }^{87} \mathrm{Sr} /{ }^{86} \mathrm{Sr}$ values of post-Marinoan

Table 1. Correlation of some Cryogenian and Ediacaran successions in Brazil and Africa, based on lower radiogenic ${ }^{87} \mathrm{Sr} /{ }^{86} \mathrm{Sr}$ ratios (best preserved samples) available and on carbon isotope shifts. D D D - Glaciogenic diamictites. Sources of information: (1) This work; (2) Sial et al. (2010); (3) Sial et al. (2000); (4) A.N. Sial (2014, unpublished); (5) Misi et al. (2007); (6) Alvarenga et al. (2014); (7) Misi \& Veizer (1998); (8) Torquato \& Misi (1977); (9) Kaufman et al. (2010); (10) Jacobsen \& Kaufman (1999); (11) Warren et al. (2011); (12) Mallmann et al. (2007); (13) Oyhantçabal et al. (2009); (14) Gaucher et al. (2004, 2009b), (15) Gaucher et al. (2007); (16) Gómez Peral et al. (2007); (17) Bagnoud-Velásquez et al. (2013); (18) Gómez Peral et al. (2014); (19) Boggiani et al. (2010); (20) Santos et al., 2000, (21) Souza (2015), (22) Alvarenga et al. (2010); (23) Chiglino et al. (2015), (24) Fraga et al. (2014) (25) Santana et al. (2016), unpublished, (26) Babinski et al. (2007), (27) Figueiredo et al. (2009).

\begin{tabular}{|c|c|c|c|c|c|c|c|c|}
\hline : & $\begin{array}{l}\text { Seridó } \\
\text { Belt (1) }\end{array}$ & $\begin{array}{c}\text { Miaba/ } \\
\text { Vaza Barris } \\
\text { Group }(2,3)\end{array}$ & $\begin{array}{l}\text { Ubajara } \\
\text { Group } \\
(4,22)\end{array}$ & $\begin{array}{c}\text { Bambui } \\
\text { Group }(5,6 \text {, } \\
9,22,26)\end{array}$ & $\begin{array}{c}\text { Bambui } \\
\text { Group } \\
(5,6,9 \text {, } \\
22,26)\end{array}$ & $\begin{array}{c}\text { Una Group } \\
(7,8, \\
25,27)\end{array}$ & $\begin{array}{c}\text { Rio Pardo } \\
\text { Basin (1) }\end{array}$ & $\begin{array}{l}\text { Rio Preto } \\
\text { Belt (1) }\end{array}$ \\
\hline 売 & & & & & & & & \\
\hline$\underset{\widetilde{C}}{\mathbb{T}}$ & $\begin{array}{c}\text { Seridó Fm. } \\
0.7078- \\
0.7081 \\
-5 \text { to }+9 \% \text { o } \\
(1)\end{array}$ & $\begin{array}{c}\text { Olhos } \\
\text { D’Água Fm. } \\
\text { Upper } \\
0.7075(2,3) \\
+10\end{array}$ & $\begin{array}{c}\text { Frecheirinha } \\
\text { Fm. } \\
0.7075(1) \\
-3.5 \text { to }+4 \% \text { o } \\
(4,23)\end{array}$ & $\begin{array}{l}\text { Lagoa do } \\
\text { Jacaré Fm. } \\
0.7074(5) \\
+8 \text { to }+12 \% \text { o } \\
\text { (5) }\end{array}$ & $\begin{array}{l}\text { Lagoa do } \\
\text { Jacaré Fm. } \\
0.7074 \text { (5) } \\
+8 \text { to } \\
+12 \% \text { (5) }\end{array}$ & $\begin{array}{l}\text { Salitre Fm. } \\
\text { Unit A1 } \\
0.7076(7) \\
+9.5\end{array}$ & $\begin{array}{l}\text { Serra do } \\
\text { Paraíso Fm } \\
\text { (Upper) } \\
+8 \% \text { o }\end{array}$ & $\begin{array}{c}\text { São Desidério } \\
\text { Fm. } \\
\text { Upper } \\
+12 \text { to }+16 \% \text { o }\end{array}$ \\
\hline : & $\begin{array}{l}\text { Jucurutu } \\
\text { Fm. } \\
0.7074- \\
0.7075 \\
-7 \text { to } \\
+10 \% \text { o (1) }\end{array}$ & $\begin{array}{c}\text { Olhos } \\
\text { D’Água Fm. } \\
\text { Lower } \\
0.7077(2) \\
-5.0 \% \text { (3) }\end{array}$ & & $\begin{array}{l}\text { Sete Lagoas } \\
\text { Fm. } \\
\text { Upper } \\
0.7077(6) \\
-5.0 \% \text { (9) }\end{array}$ & $\begin{array}{c}\text { Sete } \\
\text { Lagoas } \\
\text { Fm. } \\
0.7077(6) \\
-5.0 \% \text { (9) }\end{array}$ & $\begin{array}{l}\text { Salitre Fm. } \\
\text { Unit B1 } \\
0.7075(7) \\
-4.5 \% \text { (8) }\end{array}$ & $\begin{array}{l}\text { Serra do } \\
\text { Paraíso Fm } \\
\text { (Lower) } \\
-1.0 \%\end{array}$ & $\begin{array}{l}\text { São Desidério } \\
\text { Fm. } \\
\text { Lower } \\
+1 \text { to }+3 \% \text { o }\end{array}$ \\
\hline \multirow{4}{*}{ 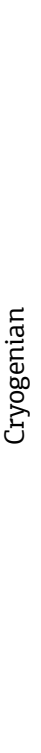 } & & $\begin{array}{l}\text { Palestina } \\
\Delta \Delta \Delta \Delta \Delta\end{array}$ & & $\begin{array}{l}\text { Inhauma } \\
\Delta \Delta \Delta \Delta \Delta\end{array}$ & $\begin{array}{l}\text { Jequitaí Fm. } \\
\Delta \Delta \Delta \Delta \Delta \Delta\end{array}$ & & $\begin{array}{l}\text { Panelinha } \\
\text { Fm. (?) }\end{array}$ & $\begin{array}{c}\text { Canabravimha } \\
\text { Fm. (?) }\end{array}$ \\
\hline & & $\begin{array}{c}\text { Jacoca/ } \\
\text { Acauã Fm. } \\
0.7072- \\
0.7076(2)\end{array}$ & & & & $\begin{array}{c}\text { Salitre Fm. } \\
\text { Unit B } \\
0.7078(7) \\
-4.4 \text { to } \\
+0.3 \% \text { (7) } \\
<669 \pm 14 \\
(25)\end{array}$ & & \\
\hline & & $\begin{array}{c}\text { Jacoca/ } \\
\text { Acauã Fm. } \\
\text { Lower } \\
\text { (cap carb) } \\
-5.0 \% \text { o }(2,3)\end{array}$ & & $\begin{array}{l}\text { Sete Lagoas } \\
\text { Fm. } \\
\text { Lower } \\
0.7075(5) \\
0.7080(22) \\
-4.5 \%(5)\end{array}$ & & $\begin{array}{l}\text { Salitre Fm. } \\
\text { Unit C } \\
\text { (cap carb.) } \\
-6.5 \% \text { \% (8) }\end{array}$ & & \\
\hline & & $\begin{array}{l}\text { Ribeirópolis } \\
\text { Fm. } \\
\text { (Jacarecica } \\
\text { Fm.) } \\
\Delta \Delta \Delta \Delta \Delta\end{array}$ & & $\begin{array}{l}\text { Jequitaí Fm., } \\
\text { Macaubas } \\
\text { Group } \\
\Delta \Delta \Delta \Delta \Delta \\
740 \pm 22(26)\end{array}$ & & $\begin{array}{c}\text { Bebedouro } \\
\Delta \Delta \Delta \Delta \Delta \\
<874 \pm 09 \\
\text { (27) }\end{array}$ & & \\
\hline
\end{tabular}


Table 1. Continued.

\begin{tabular}{|c|c|c|c|c|c|c|c|c|}
\hline 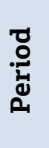 & $\begin{array}{c}\text { Northern } \\
\text { Paraguay } \\
\text { Belt } \\
(21,22)\end{array}$ & $\begin{array}{l}\text { Corumbá } \\
\text { Group (19) }\end{array}$ & $\begin{array}{l}\text { Itapucumi } \\
\text { Group } \\
\text { (Paraguay) } \\
\text { (11) }\end{array}$ & $\begin{array}{c}\text { Tucavaca } \\
\text { Belt, } \\
\text { (Bolivia) } \\
\text { (1) }\end{array}$ & $\begin{array}{c}\text { Nico Pérez } \\
\text { Terrane } \\
\text { (Uruguay) } \\
(12,14,15)\end{array}$ & $\begin{array}{c}\text { Tandilia } \\
\text { (Argentina) } \\
(16,18)\end{array}$ & $\begin{array}{c}\text { Otavi } \\
\text { Group } \\
\text { (Namibia) } \\
(9,10)\end{array}$ & $\begin{array}{c}\text { Lufilian } \\
\text { Arc } \\
\text { (DRC- } \\
\text { Zambia) (9) }\end{array}$ \\
\hline 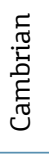 & & $\begin{array}{l}\text { Guaicurus } \\
\text { Fm. }\end{array}$ & & & $\begin{array}{c}\text { Cerro } \\
\text { Victoria } \\
\text { Fm. }-3.5 \text { to } \\
+0.6 \% \text { (15) }\end{array}$ & & & \\
\hline \multirow{5}{*}{ 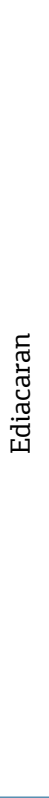 } & $\begin{array}{c}\text { Pacu Fm } \\
0.7087\end{array}$ & \multirow{2}{*}{$\begin{array}{c}543 \pm 2 \\
\text { Tamengo } \\
\text { Fm. } \\
0.7084- \\
0.7086 \\
-3.5 \text { to }+5.5 \\
\% \text { o (19) }\end{array}$} & $\begin{array}{c}\text { Cerro } \\
\text { Curuzú } \\
\text { Fm. (upper) } \\
+1.5 \% \text { (11) }\end{array}$ & \multirow{5}{*}{$\begin{array}{l}\text { Murciélago } \\
\text { Group } \\
-1 \text { to }-2 \% \text { o }\end{array}$} & \multirow{2}{*}{$\begin{array}{c}\text { Polanco Fm. } \\
\text { Yerbal Fm. } \\
0.7070- \\
0.7087 \\
-4.5 \text { to }+5.5 \\
\% \text { o (14) }\end{array}$} & \multirow{2}{*}{$\begin{array}{c}\text { Cerro Negro } \\
\text { Fm. } \\
-1 \text { to }+4.3 \% \text { o } \\
(18) \\
\text { Loma Negra } \\
\text { Fm. } \\
0.7069- \\
0.7087(16) \\
0 \text { to }+4.5 \%\end{array}$} & & \\
\hline & $\begin{array}{c}+6.5 \text { to } \\
+8.5 \% \text { o } \\
(21)\end{array}$ & & \multirow{4}{*}{$\begin{array}{c}\text { Tagatiyá } \\
\text { Guazú and } \\
\text { Camba } \\
\text { Jhopo Fm. } \\
\text { (lower) } \\
+1.8 \% \text { (11) } \\
0.7086 \text { (11) }\end{array}$} & & & & $\begin{array}{l}\text { Hüttenberg } \\
\text { Fm. } \\
0 \text { to }+12 \% \text { o } \\
\text { (9) }\end{array}$ & \\
\hline & $\begin{array}{c}\text { Nobres Fm } \\
-1.0 \text { to }+9.6 \\
\% \text { o }\end{array}$ & \multirow{2}{*}{$\begin{array}{l}\text { Bocaina Fm. } \\
-4 \text { to }+3 \% \text {. } \\
\text { (19) }\end{array}$} & & & \multirow{3}{*}{$\begin{array}{c}573 \pm 11 \\
(14) \\
\text { Las } \\
\text { Ventanas } \\
\text { Fm. } \\
\Delta \Delta \Delta \Delta \Delta \\
590 \pm 2(12)\end{array}$} & $\begin{array}{l}\text { Colombo } \\
\text { Mb. } \\
\Delta \Delta \Delta \Delta \Delta\end{array}$ & $\begin{array}{l}\text { Elandshoek } \\
\text { Fm. } \\
-3 \text { to }+8 \% \text { o } \\
\text { (9) }\end{array}$ & \\
\hline & $\begin{array}{c}\text { Guia Fm } \\
-5.5 \text { to } \\
-0.1 \% \text { o } \\
0.7076\end{array}$ & & & & & & \multirow{2}{*}{$\begin{array}{l}\text { Maieberg } \\
\text { Fm. } \\
0.7073 \text { (9) } \\
-5 \% \text { (9) }\end{array}$} & $\begin{array}{c}\text { Calcaire } \\
\text { Rose } \\
0.7075(9) \\
-4.1 \% \text { o (9) }\end{array}$ \\
\hline & $\begin{array}{c}\text { Mirassol } \\
\text { d'Oeste Fm. } \\
\text {-8.5 to }-3.5 \\
\% \text { o (22) }\end{array}$ & $\begin{array}{c}\text { Cap } \\
\text { carbonate } \\
-5 \% \text { o }\end{array}$ & & & & & & \\
\hline \multirow{4}{*}{ 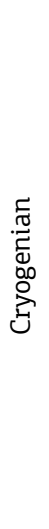 } & $\begin{array}{c}\text { Puga } \\
\Delta \Delta \Delta \Delta \Delta\end{array}$ & $\begin{array}{c}\text { Puga (?) } \\
\Delta \Delta \Delta \Delta \Delta\end{array}$ & $\begin{array}{l}\text { Vallemi } \\
\text { Fm. } \\
\text { (red beds) }\end{array}$ & & & & $\begin{array}{c}\text { Ghaub } \\
\Delta \Delta \Delta \Delta \Delta \\
635 \pm 1 \text { (9) }\end{array}$ & $\begin{array}{c}\text { Petit } \\
\text { Conglomerat } \\
\Delta \Delta \Delta \Delta \Delta\end{array}$ \\
\hline & & & & & & & $\begin{array}{l}\text { Ombaatjie } \\
\text { Fm. } \\
0.7072(10)\end{array}$ & \multirow{2}{*}{$\begin{array}{c}\text { Kokontuwe } \\
0.7066 \text { (9) } \\
-6.2 \% \text { (9) }\end{array}$} \\
\hline & & & & & & & $\begin{array}{c}\text { Rasthof Fm. } \\
0.7066 \text { (9) } \\
-5 \% \text { (9) }\end{array}$ & \\
\hline & & & & & & & $\begin{array}{c}\text { Chuos } \\
\Delta \Delta \Delta \Delta \Delta \\
746 \pm 2(9\end{array}$ & $\begin{array}{c}\text { Grand } \\
\text { Conglomerat - } \\
\Delta \Delta \Delta \Delta \Delta \\
760 \pm 5 \text { (9) }\end{array}$ \\
\hline
\end{tabular}

carbonates in NW Canada, NW Namibia, and SW Brazil (Halverson et al. 2007).

The ranges of ${ }^{87} \mathrm{Sr} /{ }^{86} \mathrm{Sr}$ ratios for the Jacoca and Olhos D'Agua formations are similar to each other $(0.7077$ to 0.7081 ), in consonance with values reported for the Marinoan Bildah, Tsabisis, and Bloeddriff cap carbonates, Kalahari Craton. However, $\delta^{13} \mathrm{C}$ values for carbonates of Jacoca Formation at the Capitão Farm are all negative, in contrast with positive values observed in middle and upper sections of the Olhos D'Agua Formation in the eastern and western Vaza Barris domains. On structural grounds, it is known that Jacoca Formation must be slightly older than the
Olhos D'Agua Formation (D'el Rey Silva 1995, 1999) and both have been weakly deformed during the Brasiliano cycle $(650-600 \mathrm{Ma})$. Smilarities of ${ }^{87} \mathrm{Sr} /{ }^{86} \mathrm{Sr}$ ratios of post-Sturtian and post-Marinoan carbonates led Babinski et al. (2007) to question the use of Sr-isotope stratigraphy to differentiate and correlate postglacial carbonate successions.

The calcium-isotope record seems to be a true archive of changes in the oceanic $\mathrm{Ca}$ isotopic compositions and early Cryogenian $\delta^{44 / 40} \mathrm{Ca}$ patterns seem to be very different from the Ediacaran ones (Silva-Tamayo et al. 2010a, 2010b). Therefore, Ca-isotope stratigraphy appears to be a promising tool to discriminate and correlate Neoproterozoic 
postglacial carbonate successions (Kasemann et al. 2005; Silva-Tamayo et al. 2010a, 2010b).

Stratigraphic changes of $\delta^{41 / 40} \mathrm{Ca}$ values of the weakly deformed carbonates of the Jacoca Formation, the deformed Cryogenian Sete Lagoas Formation, Minas Gerais, Brazil (740 \pm 22 Ma; Babinski et al. 2007, but see also discussion above) and Twitya Formation (NW, Canada) are similar, according to Silva-Tamayo et al. (2010b), in support of a Cryogenian age. The basal dolostone of the Jacoca Formation displays increasing $\delta^{44 / 40} \mathrm{Ca}_{\text {(NISTSRRM 915a) }}$ values from $0.3 \%$ to $2.0 \%$, followed by a decrease to values averaging $0.8 \%$ at the top. The overlying limestones display $\delta^{4 / 40} \mathrm{Ca}$ (NISTSRM 915a) values averaging 1.0\%o (Silva-Tamayo et al. 2010a).

The basal shallow-marine cap dolostone of the Acauá Formation displays $\delta^{44 / 40} \mathrm{Ca}_{\text {(NIST-SRM 915a) }}$ values averaging $0.7 \%$ according to Silva-Tamayo et al. (2010a) with a stepwise decrease to values around $0.2 \%$ at the base of the overlying limestone succession, followed by a rapid increase to $1.0 \%$ upsection. The Ca-isotope stratigraphic pathway displayed by this cap carbonate, according to these authors, is indistinguishable from those displayed by cap carbonates overlying $c a .635$ Ma glacial deposits in NW Namibia.

\section{OTHER TERRANES IN THE BORBOREMA PROVINCE}

\section{Seridó Belt: Jucurutu and Seridó formations}

The Seridó Belt in northeastern Brazil encompasses a metavolcano-sedimentary sequence that was deposited discordantly on a Paleoproterozoic basement, and has been intensely studied in the last fifty years (Fig. 21). This belt was affected by a strong transpressional deformation, intrusion of voluminous granitic magmas, and reworking by transcurrent structures that imparted an N-NE trend to this belt. The original stratigraphic relationships have been obscured by intense deformation and this led to divergent interpretations of the sedimentation age, stratigraphy, and evolution of the supracrustal rocks, in spite of several geochronological, geochemical, and structural studies (Jardim de Sá et al. 1988, 1994; Caby et al. 1995; Archanjo et al. 2013; Van Schmus et al. 2003; Hollanda et al. 2015).

Among several stratigraphic schemes proposed for the Seridó Belt, the most commonly used (Jardim de Sá \& Salim 1980) includes all metasedimentary rocks of this belt in the Seridó Group. This group is subdivided from base to top into:

1. Jucurutu Formation, composed of a basal conglomerate, iron-formation, marble layers intercalated in gneisses, mica-schist, quartzite, calc-silicate rocks and metavolcanic rocks;

2. Equador Formation, predominantly composed of quartzite with metaconglomerate lenses, which become more abundant toward the top, calc-silicate rocks and paragneisses; and

3. the Seridó Formation, which is made up of metaconglomerate, feldspathic, or aluminous mica-schist with subordinate marble, calc-silicate rocks, paragneiss, basic metavolcanic rocks, and quartzite.

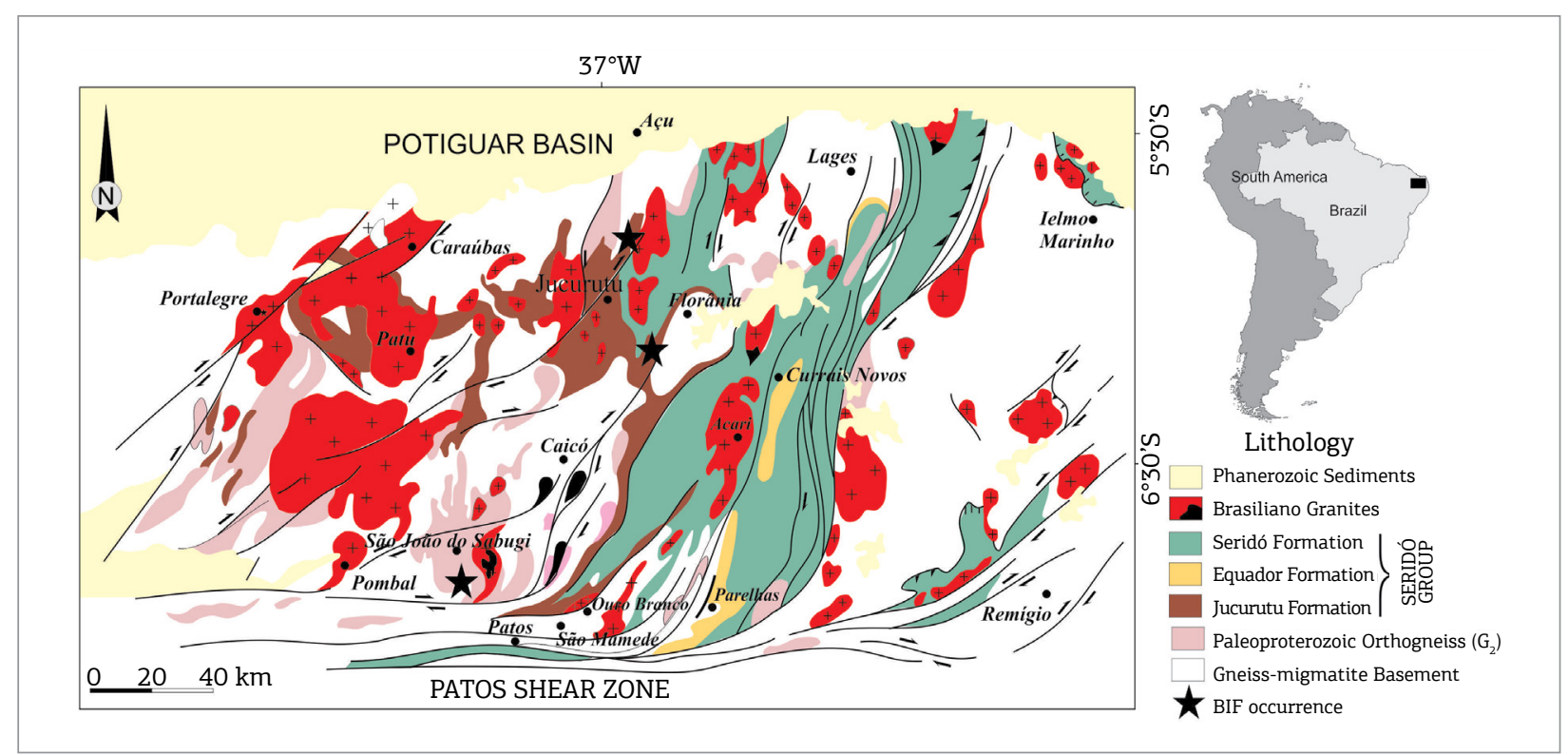

Figure 21. Simplified geological map of the Seridó Belt (after Jardim de Sá, 1994; Angelim et al. 2006; modified from Sial et al. 2015). Black stars represent locations of BIFs (Bonito iron Mine, Serra da Formiga and Riacho Fundo). 
The Equador Formation exhibits variable thickness and can be absent in certain portions of the belt (Jardim de Sá 1994 and references therein). In this scheme, the whole package in the Seridó Belt resulted from a megacycle of sedimentation lacking regional unconformities. The association of iron formation, marble and calc-silicate paragneisses of the Jucurutu Formation could be of shallow-marine environment, although the banded iron formation (BIF) depositional environment could be slope or basinal. The Equador Formation is the siliciclastic component of this shallow-marine association, while mica-schists of the Seridó Formation correspond to a thick package of turbiditic, flyschoid deposits marking the inversion of the basin, according to Jardim de Sá (1994).

A different stratigraphic column was proposed by Caby et al. (1995) in which supracrustal rocks were subdivided into the Jucurutu Group and the overlying Seridó Group with a hiatus (regional unconformity) of deposition between them. Recently reported U-Pb ages of detrital zircons and $\mathrm{Nd}$ isotope compositions from the Seridó Group indicate a significant change of sediment provenance during the deposition of sands and conglomerates and the overlying greywacke-pelite sequences (Hollanda et al. 2015). According to these authors, this shift in provenance defines an unconformity in the Seridó Group characterized by a metadiamictite horizon with pebbles and cobbles from the Paleoproterozoic to Archean basement and recycled quartzites of the underlying Equador Formation. The change in provenance is defined by a cryptic internal disconformity that is characterized by a time gap of about $1.0 \mathrm{Ga}$ in the age of the detrital zircons. $\mathrm{Nd}$ compositions across this unconformity indicate that the pelites are very radiogenic $\left(\varepsilon \mathrm{Nd}_{\text {present-day }}=-4\right.$ to -11$)$ compared with the sandy deposits $\left(\varepsilon \mathrm{Nd}_{\text {present-day }}=-22\right.$ to -31). The provenance of the metapelites at the top of the metasedimentary succession includes a prominent population of Cryogenian zircons whose youngest grains dated to between 0.64 and $0.62 \mathrm{Ga}$. According to Hollanda et al. (2015), these zircons were deposited in a basin developed on continental basement that preserves remnants of nearshore to terrestrial deposits with no detrital zircons younger than 1.8 Ga. More importantly, Hollanda et al. (2015) have raised the possibility that the Equador Formation lies stratigraphically below the Jucurutu Formation and that the Seridó and Jucurutu formations could actually be equivalent stratigraphically.

In the Jucurutu Formation, metric to decametric-scale marble layers, sometimes compositionally banded, are abundant and occur at three stratigraphic levels, one of which is near the base of the succession (Jardim de Sá 1994; Nascimento et al. 2007). In the Seridó Formation, marble layers are less abundant and are only found near the base of this formation (extensional tectonic stage). The lack of carbonates in the latter is due to the tectonic inversion (early compressional stage) in the evolution of the basin (Jardim de Sá 1994). Marble layers intercalated in the Jucurutu Formation are found in the northern, central, southern, and western portions of the Seridó Belt.

Investigation on TDM model ages of metasedimentary rocks (Van Schmus et al. 1996) suggests maximum ages between 1.6 and 1.2 Ga for the Jucurutu and Seridó formations. Van Schmus et al. (2003) determined U-Pb SHRIMP ages of detrital zircons from a paragneiss (EC-61) of the Jucurutu Formation from its type area, finding a youngest age of $634 \pm 13 \mathrm{Ma}$. These authors also reported an U-Pb SHRIMP age of $628 \pm 16 \mathrm{Ma}$ for detrital zircons from the younger Seridó Formation using a mica-schist sample collected near Pedra Preta, state of Rio Grande do Norte. These data suggested that the maximum depositional age for the Jucurutu and Seridó formations is ca. $630 \mathrm{Ma}$, preceding the peak of metamorphism in the Brasiliano (= Pan-African) orogeny in this region (ca. 600 - $585 \mathrm{Ma}$; Hollanda et al. 2010). However, newly reported $\mathrm{U}-\mathrm{Pb}$ zircon ages for the Acari granite $(577$ - $572 \mathrm{Ma})$ and Santa Luzia migmatite constrain the HT/LP metamorphism of the Seridó to $575 \mathrm{Ma}$ (Archanjo et al. 2013).

Depending on the nature of the supracrustal rocks, as well as on the tectonic and metamorphic history of the region, it is difficult to date rocks by radiogenic methods, and $\mathrm{C}$ and $\mathrm{Sr}$ chemostratigraphy may assist resolve issues such as stratigraphy and sedimentation age (Melezhik et al. 2001). In highly metamorphosed regions (e.g. amphibolite facies), as is the case throughout most of the Seridó Belt, the interpretation of depositional patterns of sedimentation, as well as $\mathrm{C}$ - and $\mathrm{Sr}$-isotope variations, can be severely compromised. In a preliminary attempt to estimate the age of deposition of carbonate rocks of the Seridó Group (Jucurutu and Seridó formations) using C-and Sr-isotope chemostratigraphy, Nascimento et al. $(2004,2007)$ have examined nine marble layers and proposed a depositional age around $600 \mathrm{Ma}$.

As part of the meta-volcanosedimentary Seridó Belt, BIFs abound and the couplet formed by BIFs in sharp contact with overlying carbonate rocks of the Jucurutu Formation may represent a record of deposition in the aftermath of one of the Neoproterozoic glaciations. To help addressing this issue, Sial et al. (2015a) have examined field relationships, behavior of $\mathrm{C}$ and $\mathrm{Sr}$ isotopes in carbonates of the Jucurutu Formation, Cr isotopes in BIF and carbonates, and rare-earth elements in both carbonates and BIFs. Six sections were sampled across marble layers of the 
Jucurutu Formation, and two drill cores from the Bonito iron Mine have been studied. One of these sections is located at the western flank of the Bonito iron Mine antiform, about $20 \mathrm{~km}$ north of the town of Jucurutu. At this locality, drill cores from boreholes BTO-34 (240 m) and BTO-78 (16 m) of the MHAG Mining Company have been micro-drilled. The $\delta^{13} \mathrm{C}$ shows large variation and in the BTO-34 drill hole, displays values from -12 to $-5 \%$ o at the base followed up section by a shift to positive values (+4 to $+10 \%$, Fig. 22). A similar trend is observed for drill core 78 , but carbonates at the contact with underlying BIF show a more vigorous $\delta^{13} \mathrm{C}$ fluctuation, with values as low as $-12 \%$ in their lowest portion. No clear correlation exists between $\delta^{13} \mathrm{C}$ and $\delta^{18} \mathrm{O}$ for these samples, except for $\delta^{13} \mathrm{C}$ values below $-5 \%$, which also exhibit the most negative $\delta^{18} \mathrm{O}$ values. Apart from these few samples, $\delta^{13} \mathrm{C}$ values probably represent near-primary isotope signals. Nascimento et al. $(2004,2007)$ found no co-variation between $\delta^{13} \mathrm{C}$ and $\mathrm{Mn} / \mathrm{Sr}$ ratios or between $\delta^{13} \mathrm{C}$ and $\delta^{18} \mathrm{O}$ for carbonates of the Jucurutu Formation, supporting the primary nature of isotopic signals.

Two sections across marble layers (surface samples) were studied near the town of Ouro Branco (Sial et al. 2015a). One of these sections is only $300 \mathrm{~m}$ from diamictite outcrops and the other section at about $1 \mathrm{~km}$ northwest from this locality. There is no clear stratigraphic relationship between the Ouro Branco diamictite and these marble layers, which show little variation of $\delta^{13} \mathrm{C}$ and $\delta^{18} \mathrm{O}, \delta^{13} \mathrm{C}$ ranging between +8.9 and $+9.7 \%$ o. As a whole (the two sections), $\delta^{18} \mathrm{O}$ varies from -13.0 to to $-7.2 \%$ VPDB.

Sial et al. (2015a) studied three sections of marble layers at Serra da Formiga. All show positive $\delta^{13} \mathrm{C}$ values ranging from +2.9 to $+8.3 \%$ o VPDB while $\delta^{18} \mathrm{O}$ values vary from -11 to $-6.2 \%$ VPDB. Marble layers associated with BIF at the Riacho Fundo locality display positive $\delta^{13} \mathrm{C}$ values within the $7-9 \%$ interval, a range similar to that observed in a marble layer of the the Jucurutu Formation, at the town of Jucurutu, reported by Nascimento et al. (2007).

Marbles of the Jucurutu Formation were metamorphosed up to amphibolites facies, precluding the use of $\delta^{18} \mathrm{O}$ as an indicator of seawater composition. An ample fluctuation of $\delta^{18} \mathrm{O}$ values, from -16 to -3 to $\%$ VPDB is observed, probably in response to metamorphism or weathering imprint. At the Cruzeiro da Maniçoba locality, near Currais Novos town, basal pink dolostones from the younger Seridó Formation show $\delta^{13} \mathrm{C}$ values around $-4 \%$ and $\delta^{18} \mathrm{O}$ from -16.5 to $-12 \%$ VPDB. Positive $\delta^{13} \mathrm{C}$ values around $+9 \%$ in marbles of the Seridó Formation (e.g. São Mamede) have been reported by Nascimento et al. (2007). It became clear to Sial et al. (2015a) that the Jucurutu and Seridó Formations exhibit negative $\delta^{13} \mathrm{C}$ values at their base followed upsection by high positive values,

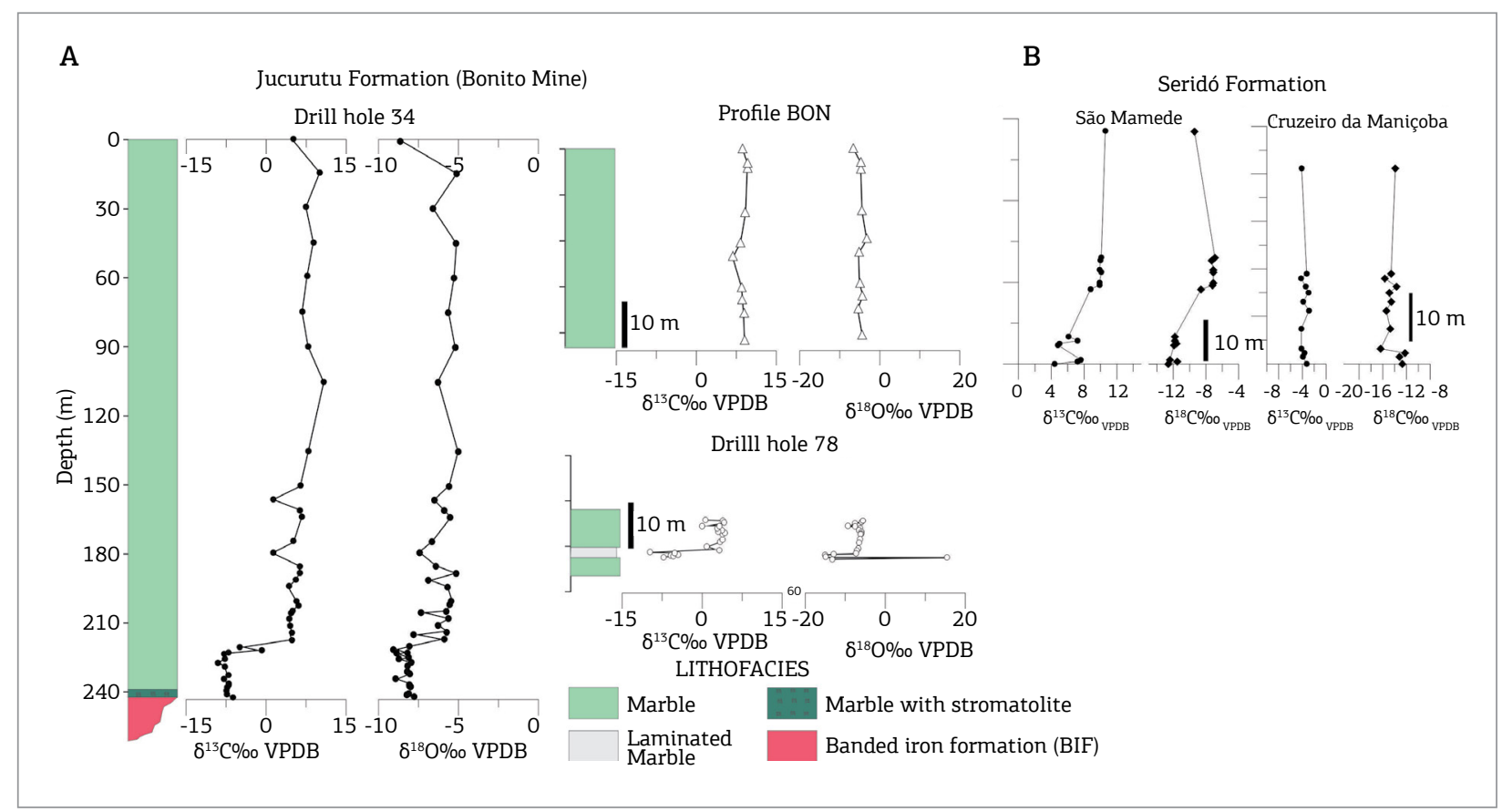

Figure 22. (A) C- and O-isotope chemostratigraphic profiles for marbles of the Jucurutu Formation overlying BIFs at the Bonito iron Mine (drill holes 34 and 78; profile BON corresponds to a section at about the hinge of the antiform of the Bonito iron Mine); (B) C- and O-isotope chemostratigraphic profiles for marbles of the Seridó Formation (São Mamede and Cruzeiro da Maniçoba localities). Modified from Sial et al. 2015. 
something which was not depicted from the sections studied by Nascimento et al. (2007).

Nascimento et al. (2007) determined ${ }^{87} \mathrm{Sr} /{ }^{86} \mathrm{Sr}$ ratios for Jucurutu carbonates between 0.7074 and 0.7075 and between 0.7078 and 0.7083 for the Seridó Formation. Sial et al. (2015a) analyzed ${ }^{87} \mathrm{Sr} /{ }^{86} \mathrm{Sr}$ ratios in marbles from the Jucurutu Formation at the Bonito iron Mine (10), Ouro Branco (10), Serra da Formiga (3), and Riacho Fundo (2) sections. Samples from the Bonito iron Mine yielded consistent results, between 0.7074 and 0.7075 , the same as reported by Nascimento et al. (2007) from samples from Jucurutu town (type area). Samples from the Ouro Branco and Serra da Formiga sections yielded values between 0.7074 and 0.7076 . Most of the analyzed samples are pure limestones with high Sr contents (up to $3000 \mathrm{ppm}$ ) and very low $\mathrm{Rb}(<10 \mathrm{ppm})$, thus the measured isotopic compositions likely represent primary signals. ${ }^{87} \mathrm{Sr} /{ }^{86} \mathrm{Sr}$ values for dolomitic carbonates of the Seridó Formation at Cruzeiro da Maniçoba section obtained in this study are considerably higher $(0.7077-0.7139)$ and are less consistent, as expected for dolostones.

Usually, highly metamorphosed carbonates have C and $\mathrm{Sr}$-isotope patterns severely complicated by isotopic re-equillibration due to metamorphic reactions. However, marbles of the Seridó Belt seem to preserve near primary $\mathrm{C}$ - and $\mathrm{Sr}$-isotope ratios, as known from other successions up to the high metamorphic grade (Melezhik et al. 2008; Chiglino et al. 2010). This is probably due to their pure calcitic composition, which determined only very limited metamorphic reactions between different mineral phases. In the particular case of the Jucurutu Formation, Nascimento et al. (2007) show that near-primary, unaltered ${ }^{87} \mathrm{Sr} /{ }^{86} \mathrm{Sr}$ values are encountered in samples with $\delta^{18} \mathrm{O}>-15 \%$ VPDB, Sr concentrations $>2000 \mathrm{ppm} \mathrm{Sr}$ and $\mathrm{Mn} / \mathrm{Sr}<0.05$. All samples of the Jucurutu Formation that yielded ${ }^{87} \mathrm{Sr} /{ }^{86} \mathrm{Sr}$ values in the range $0.7074-0.7076$ fulfill these criteria and are interpreted as near-primary.

The ${ }^{87} \mathrm{Sr} /{ }^{86} \mathrm{Sr}$ ratios range observed in the Jucurutu Formation is compatible with values reported for the late Cryogenian (Halverson et al. 2005, 2010), although similar ${ }^{87} \mathrm{Sr} /{ }^{86} \mathrm{Sr}$ values also occur in the Ediacaran (to which ferruginous deep-waters were also associated) as registered in Cloudina-bearing limestones in Uruguay (Gaucher et al. 2009; Frei et al. 2011) and Argentina (Gómez Peral et al. 2007). One cannot discard, however, that seawater has likely undergone important changes of its ${ }^{87} \mathrm{Sr} /{ }^{86} \mathrm{Sr}$ ratios after major Neoproterozoic glacial events due to input of continental waters from ice melting and strong weathering in continents, blurring the true seawater ${ }^{87} \mathrm{Sr} /{ }^{86} \mathrm{Sr}$ values during deposition of carbonates (Zhao et al. 2009).
Recently, chromium stable isotopes in BIFs and ironrich cherts have been shown to reflect the redox sensitivity of the $\mathrm{Cr}$ (III) - Cr(VI) pair in geological and oceanographic processes (Frei et al. 2009). Chromium is highly sensitive to the redox state of the surface environment, oxidative weathering processes producing the oxidized hexavalent Cr. Oxidation of the reduced $\mathrm{Cr}$ on land is accompanied by isotopic fractionation (Frei et al. 2009 and references therein). The isotopic systematic of the chromium cycle including incorporation into BIF has been discussed into details by Lyons \& Reinhard (2009). Stable Cr isotopes from BIFs and Fe-chert can track the presence of hexavalent $\mathrm{Cr}$ in Precambrian oceans providing a picture of the oxygenation history of the Earth's atmosphere-hydrosphere system as demonstrated by Frei et al. (2009). Chromium stable isotopes in Fe-rich chemical sediments deposited during glacial events are suitable for tracing oxygenation of surface environments through Earth's history. Besides, $\mathrm{Cr}$ isotopes in carbonates may be useful as a tracer for climate change and for reconstructing the redox state of ancient seawater (Frei et al. 2011; Bonnand et al. 2013).

Cr-isotope data for late Neoproterozoic BIFs reported by Frei et al. (2009) include 755 - 730-Myr-old Rapitan BIF, deposited during the early Cryogenian ('Sturtian') glaciation, the Marinoan-aged Chuos BIF, Namibia, and BIF- and Fe-bearing cherts of the 570 - 550-Ma Yerbal and Cerro Espuelitas formations, Uruguay, deposited well after the Gaskiers glaciation (Frei et al. 2009, 2013). BIFs deposited during the late Neoproterozoic record strongly positive $\delta^{53} \mathrm{Cr}$ values ranging from $0.5 \%$ o to $4.9 \%$. This supports the occurrence of a Neoproterozoic oxygenation Event (NOE) which was accompanied by tectonic upheaval, climatic extremes, and biological innovations (Shields-Zhou \& Och, 2011; Och \& Shields-Zhou 2012). However, Cr isotope data available for the late Neoproterozoic are limited to a few units, and suggestions for widespread ocean anoxia during the NOE (Shields-Zhou \& Och 2011) request further information from the $\mathrm{Cr}$-isotope tracer system.

In an attempt to provide information on the redox state of oceans in the early Ediacaran, Døssing et al. (2010) applied $\mathrm{Cr}$ isotope systematics to the Jacadigo Group, a glacio-marine succession in central Brazil deposited after $700 \mathrm{Ma}$ (Babinski et al. 2013). This group is composed of the Urucum Formation (sandstones) at the base and the Santa Cruz Formation (BIF) at the top. Cr stable isotope measurements on various BIF horizons of the Santa Cruz Formation yielded mostly positive $\delta^{53} \mathrm{Cr}$ values up to $+0.9 \%$, while the Fe-rich glaciogenic diamictites and associated BIF of the likely correlative Puga Formation yielded $\delta^{53} \mathrm{Cr}$ values from to +0.1 to $+0.4 \%$. According to Døssing et al. (2010) and Gaucher et al. (2015), these 
positively fractionated values speak for the occurrence of atmospheric oxygenation pulses during deglaciation stages, which enabled the oxidative weathering and mobilization of trivalent $\mathrm{Cr}$ into the oceans.

Sial et al. (2015a) have analyzed $\mathrm{Cr}$ isotopes in BIFs and overlying carbonates of the Jucurutu Formation. The $\mathrm{Cr}$ concentrations of these BIFs are remarkably high compared to other iron formations (e.g. Frei et al. 2009), with values between 85 and $400 \mathrm{ppm}$. The Jucurutu BIFs are also characterized by high-temperature magmatic $\delta^{53} \mathrm{Cr}$ values $\left(\delta^{53} \mathrm{Cr}=-0.123 \pm 0.102 \%\right.$; Schoenberg et al. 2008; Crowe et al. 2013), unlike the other late Neoproterozoic BIFs so far analyzed (Frei et al. 2009, 2013; Døssing et al. 2010) which all yielded strongly positively fractionated $\delta^{53} \mathrm{Cr}$ signatures. Whereas $\delta^{53} \mathrm{Cr}$ values for $\mathrm{BIF}$ from the Bonito iron Mine vary from -0.23 to $-0.12 \%$ o (Cr concentration: 85 to $200 \mathrm{ppm}$ ), BIF from the Serra da Formiga and Saco Redondo yielded $\delta^{53} \mathrm{Cr}$ values from -0.31 to $-0.14 \%$ o (Cr concentration: 110 to $300 \mathrm{ppm}$ ). BIFs from the Riacho Fundo locality display the lowest $\delta^{53} \mathrm{Cr}$ values in the interval of -0.42 to $-0.14 \%$ o ( $\mathrm{Cr}$ concentration: 220 to $400 \mathrm{ppm}$ ).

At two sections (Saco Redondo and Riacho Fundo), the more negative $\delta^{53} \mathrm{Cr}$ values occur in the top $5 \mathrm{~m}$ of section and could be related to the effect of surface weathering, which mobilizes positively fractionated $\mathrm{Cr}(\mathrm{VI})$ and leaves negatively fractionated soils behind (Berger \& Frei 2013; Frei \& Polat 2013; Crowe et al. 2013). However, unweathered drill core samples from the Bonito Mine also show negative $\delta^{53} \mathrm{Cr}$ values throughout a 30 -m-thick section, between 115 and $146 \mathrm{~m}$ depth. It is unrealistic to assume significant weathering for samples at $>100 \mathrm{~m}$ depth in a semi-arid area such as the Seridó Belt. Furthermore, other lines of evidence indicate that negative $\delta^{53} \mathrm{Cr}$ values are not the product of weathering, but represent primary features of the Jucurutu BIF, namely:

1. Surface samples yielded essentially the same $\delta^{53} \mathrm{Cr}$ values as those from $>100 \mathrm{~m}$ deep boreholes, showing that weathering is not the cause of the observed negative $\mathrm{Cr}$ isotope ratios;

2. Cr concentrations of the Jucurutu BIF are so high (avg. $220 \mathrm{ppm}$ ) that it would necessitate an unrealistic fluid-rock interaction during weathering to change the isotopic composition;

3. If weathering is responsible for the observed negative $\delta^{53} \mathrm{Cr}$ values, overlying carbonates must have suffered similar or even worse alteration. With much lower $\mathrm{Cr}$ concentrations in the carbonates (avg. $6 \mathrm{ppm}$ ), their isotopic composition should have been altered even more than BIFs. However, they yielded similar or even higher $\delta^{53} \mathrm{Cr}$ values than BIFs, which cannot be explained if weathering played a significant role in their isotopic composition.

To assess the degree of detrital contamination, Sial et al. (2015a) have plotted Sc concentrations for the studied BIFs and marbles samples against $\delta^{53} \mathrm{Cr}$. All samples consistently plot outside the detrital Cr-dominated field for $\delta^{53} \mathrm{Cr}$ (Frei et al. 2013), suggesting that the basin was characterized by minimal terrigenous input from the continent. The negative $\delta^{53} \mathrm{Cr}$ values reported by Sial et al. (2015a) probably is a record of primary signals, related to hydrothermal vents (see below).Marble samples in the Bonito iron Mine have "normal" Cr concentrations ( $1-3 \mathrm{ppm})$ and marbles from the Riacho Fundo and Serra da Formiga localities display slightly higher $\mathrm{Cr}$ values $(4-10 \mathrm{ppm})$. Apart from a few carbonate samples from the Bonito iron Mine which are slightly positively fractionated $\left(\delta^{53} \mathrm{Cr}\right.$ around $\left.-0.05 \%\right)$, the other samples have unfractionated $\delta^{53} \mathrm{Cr}$ values within the high-temperature magmatic field.

\section{Ubajara Group: Frecheirinha Formation}

The Frecheirinha Formation is a carbonate unit about $500 \mathrm{~m}$ in thickness whose type area is located near the Frecheirinha town, state of Ceará (Fig. 23), and the best exposures are observed at the quarry of the Companhia Cearense de Cimento Portland, north of the Aprazivel village (Chiglino et al. 2015 and references therein). The strata exhibit intense ductile deformation recorded by folds with axes with a NE-SW trend and, locally, low-grade metamorphism.

Carbonate rocks are represented by limestones and marly rythmites in the lower part of the formation, passing into dark gray to gray, fine, laminated, stromatolitic limestones at the top. In the Araticum area, carbonates are composed of fine-grained, calcitic mudstones (grain size: $10 \mathrm{~mm}$ ) intercalated with organic-rich marls in which microfossils are preserved. On the other hand, in the Angustura Farm region recrystallization of carbonates is evident, and the occurrence of tremolite in these limestones indicates lowgrade metamorphic conditions. This metamorphism was probably caused by the intrusion of the nearby Mucambo granite and is not regional in nature.

Chiglino et al. (2015) selected the Araticum profile, located between the Frecheirinha and Ubajara villages, for palynological study because of the lower thermal overprint. There, limestone-marl rhythmites occur at the base, which pass into dark gray to black, finely laminated, organic-rich limestones, at the top.

Barroso et al. (2014) reported the occurrence of probable soft-bodied Ediacaran fossils in the overlying Jaibaras Group, similar to the White Sea assemblage, which could assure an Ediacaran age to this unit (560 - $542 \mathrm{Ma}$, Narbonne 2005; 
Fedonkin et al. 2007). These biostratigraphic relationships can provide a minimum late Ediacaran age for the Frecheirinha Formation, but it needs more detailed study to prove the paleontological affinity of the fossils. The certification of a real relationship with the fossils of the Ediacara fauna needs more investigation.
The age of the Ubajara Group is still uncertain due to the lack of reliable radiometric ages. The minimum age is constrained by the following ages:

1. a Rb-Sr age of $562 \pm 19$ Ma determined for the Coreaú dike swarm, which crosscuts the sequence (Sial \& Long 1987);

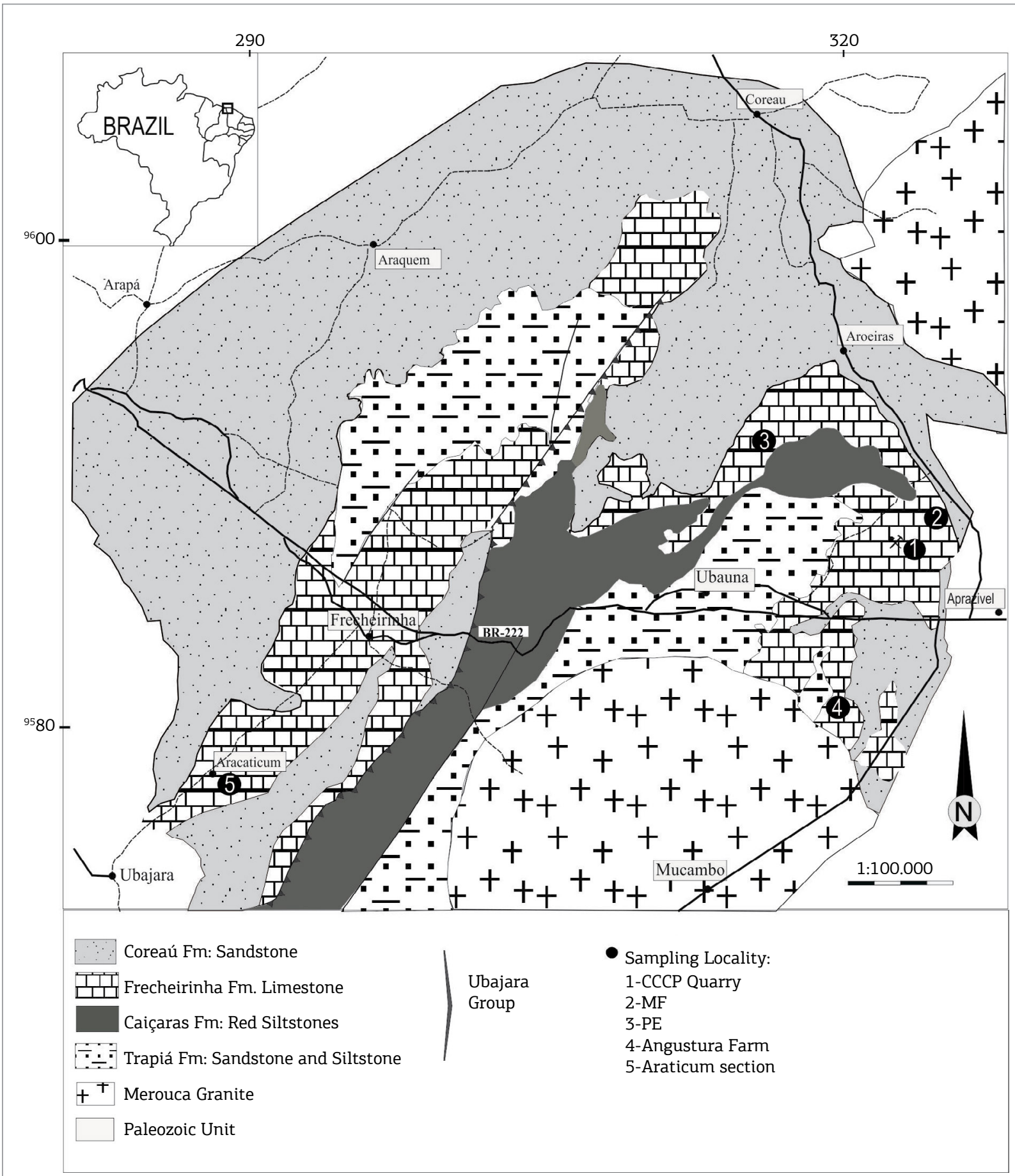

Figure 23. Geological map showing the Ubajara Group and area of outcrop of the Frecheirinha Formation (Araticum Section). Modified from Chiglino et al. (2015). 
2. the Mucambo granite intrudes the Ubajara Group and yielded a U-Pb crystallization age of $532 \pm 7 \mathrm{Ma}$ (Santos et al. 2008); and

3. a Rb-Sr age of $540 \pm 24 \mathrm{Ma}$ (Sial 1989), a U-Pb age of $532 \pm 24 \mathrm{Ma}$ (Fetter et al. 2003), and a U-Pb SHRIMP age of $541 \pm 5 \mathrm{Ma}$ (Santos et al. 2013) for the Meruoca granite, which intrudes the group and develops an important contact aureole. The U-Pb SHRIMP age of $541 \mathrm{Ma}$ is considered the best age estimate for the crystallization of the pluton.

Chemostratigraphic data presented by Chiglino (2013) show negative $\delta^{13} \mathrm{C}$ values of $-3.5 \%$ at the base, passing up section into a positive excursion with maximum values of $+3.7 \%$ o (Fig. 24). Corresponding ${ }^{87} \mathrm{Sr} /{ }^{86} \mathrm{Sr}$ values range between 0.7075 and 0.7080 (Sial et al. 2003). Especially the $\mathrm{Sr}$ isotope ratios, which were obtained from high-Sr limestones ( $\mathrm{Sr}$ concentration up to $3500 \mathrm{ppm}$; Chiglino 2013), favor a latest Cryogenian to Ediacaran depositional age (e.g. Halverson et al. 2007). However, latest Cryogenian successions are often characterized by elevated $\delta^{13} \mathrm{C}$ values of up to $+8 \%$ o which drop to negative values before the end-Cryogenian glaciation (Halverson et al. 2005). This pattern is not observed in the Frecheirinha Formation. Instead, a plateau around $+3 \%$ characterizes most of the unit and postdates a negative excursion, similar to that observed for the late Ediacaran Nama and Corumbá groups (Grotzinger et al. 1995; Boggiani et al. 2010), which also yielded similar acritarchs as the Frecheirinha Formation (Chiglino et al. 2015). Likewise, a negative excursion followed by moderately positive values is also observed in the late Ediacaran upper Polanco Formation (Arroyo del Soldado Group, Uruguay), which is also associated to ${ }^{87} \mathrm{Sr} /{ }^{86} \mathrm{Sr}$ values between 0.7070 and 0.7082 (Gaucher et al. 2009; Frei et al. 2011). Thus, the chemostratigraphic data suggest an Ediacaran age as the most probable depositional age of the Frecheirinha Formation, but so far do not allow a more refined geochronology.

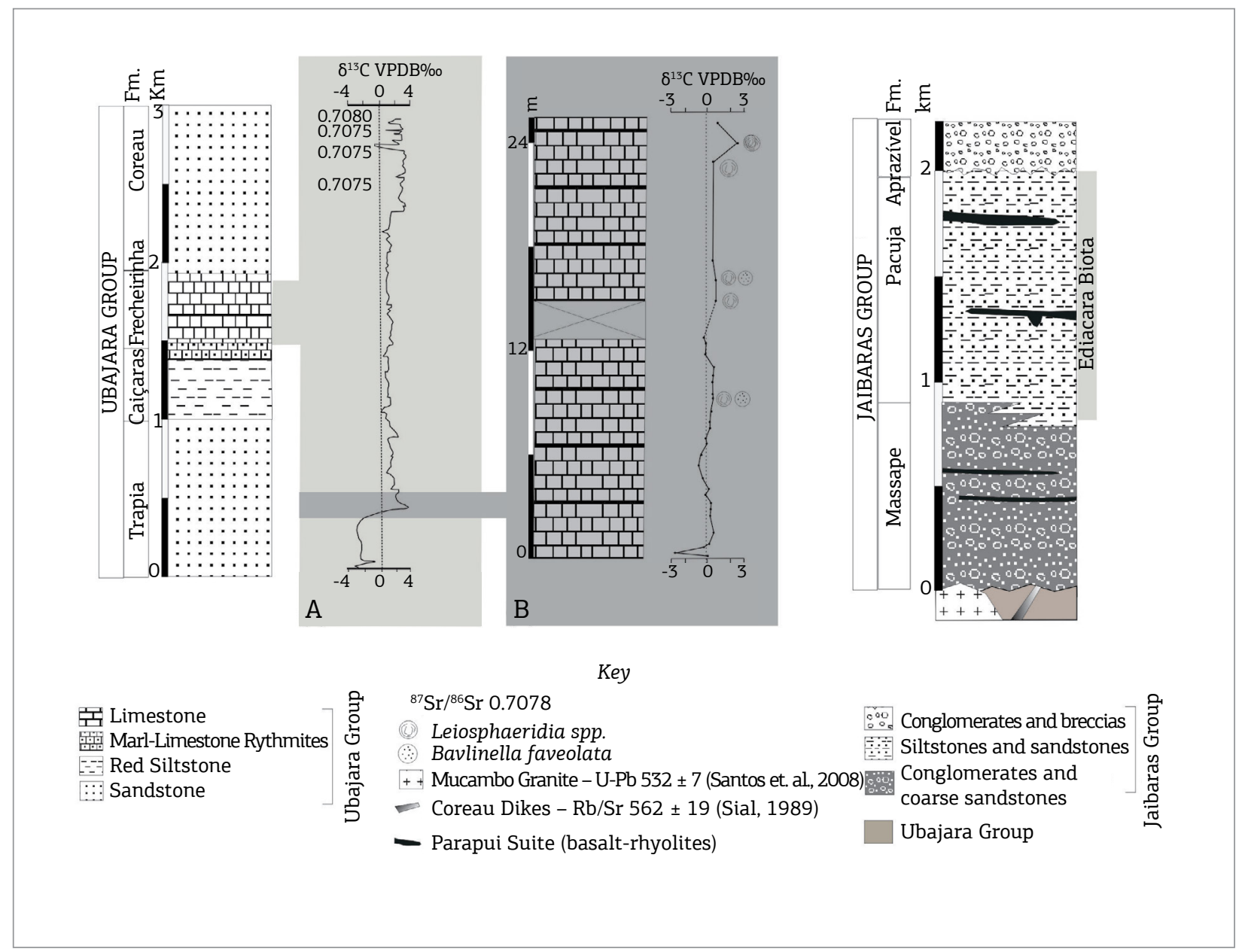

Figure 24. Lithostratigraphy of the Ubajara and Jaibaras groups, showing stratigraphic range of fossils occurring in these units. (A) $\delta^{13} \mathrm{C}$ and ${ }^{87} \mathrm{Sr} /{ }^{86} \mathrm{Sr}$ chemostratigraphy of the Frecheirinha Formation (Sial et al. 2003, Chiglino 2013); (B) Detail of the stratigraphic interval sampled (Chiglino et al. 2015). 


\section{RIO DE LA PLATA CRATON (URUGUAY AND ARGENTINA)}

Neoproterozoic carbonate deposits occur both at the eastern and western sides of the Río de la Plata Craton (RPC). Whereas successions deposited at the eastern side are well preserved and largely unmetamorphosed (e.g. Gaucher et al. 2008a; Poiré \& Gaucher, 2009), carbonates occurring at the western side were strongly deformed and metamorphosed during the Early Cambrian Pampean Orogeny. Due to this fact there is a paucity of chemostratigraphic studies at the western boundary of the RPC; of interest are those of the Puncoviscana Formation (Toselli et al. 2012) and carbonates of the Difunta Correa Sequence (Galindo et al. 2004). The latter unit may be unrelated to the RPC and only later tectonically accreted (e.g. Ramacciotti et al. 2015).
At the eastern side of the RPC, Neoproterozoic sedimentary units crop out in two different tectonostratigraphic terranes (Fig. 25), namely:

1. Nico Pérez Terrane, which crops out mainly in Uruguay, but also in southernmost Brazil. Neoproterozoic successions include the Las Ventanas and Playa Hermosa formations, the Arroyo del Soldado Group and the Marco de los Reyes Formation, and only the two latter units contain carbonates. As will be shown below, all these units are Ediacaran to lowermost Cambrian in age;

2. Tandilia Terrane, in the sense of Bossi and Cingolani (2009) and Abre et al. (2014), crops out both in the Tandilia area in Argentina (Buenos Aires Province) and in southern Uruguay. The Neoproterozoic units occurring in the Tandilia Terrane include the Sierras Bayas Group in Argentina, and its likely correlative Piedras

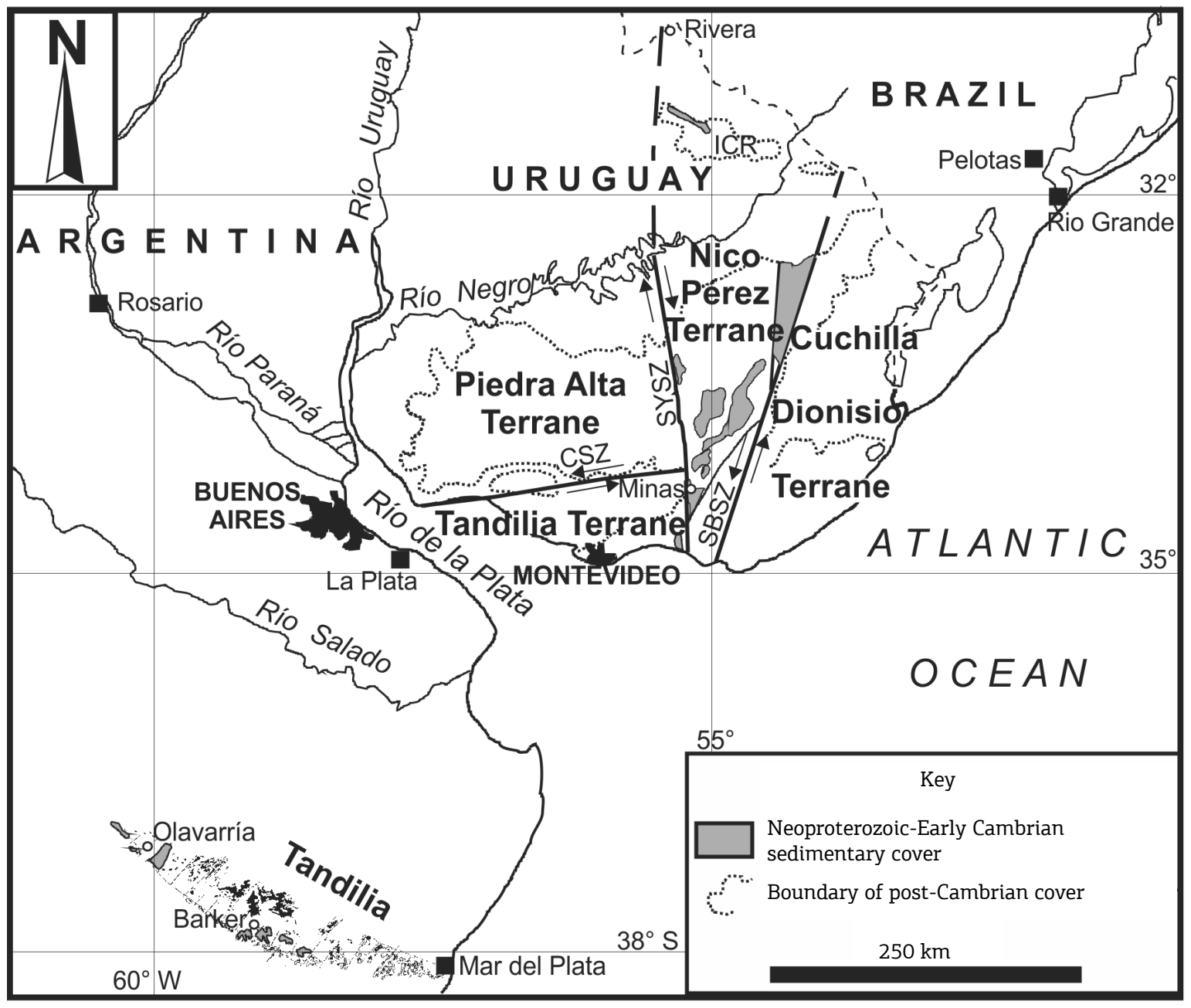

Figure 25. Simplified map of the eastern Río de la Plata Craton, showing outcrop areas of the Arroyo del Soldado Group (Nico Pérez Terrane), Piedras de Afilar Formation and Sierras Bayas Group (Tandilia). Modified from Gaucher et al. (2005, 2008a). ICR: Isla Cristalina de Rivera; CSZ: Colonia Shear Zone; SYSZ: Sarandí del Yí Shear Zone; SBSZ: Sierra Ballena Shear Zone. 
de Afilar Formation in Uruguay (Pamoukaghlián et al. 2014). These units are also largely Ediacaran in age.

\section{Arroyo del Soldado Group (Uruguay)}

The opening of the Arroyo del Soldado basin is recorded in the underlying rift deposits of the Las Ventanas and Playa Hermosa formations. The Las Ventanas Formation represents a deepening-upward sequence with conglomerates at the base and middle, passing into sandstones and finally shales with marine acritarchs at the top (Masquelin \& Sánchez Bettucci 1993; Blanco \& Gaucher 2005, 2014; Gaucher et al. 2008b). Basalts occur at the base of the unit and acid volcanics and pyroclastics at the top, representing synsedimentary, bimodal volcanism (Gaucher et al. 2008b).

The ages of volcanic rocks allow constraining the deposition of the Las Ventanas Formation between $590 \pm 2 \mathrm{Ma}$ and $573 \pm 11 \mathrm{Ma}$ (Mallmann et al. 2007; Oyhantçabal et al. 2009). Glaciogenic diamictites occurring in the lower third have been correlated with the Gaskiers Glaciation (Blanco \& Gaucher 2005; Gaucher et al. 2008b) which took place at ca. $583 \mathrm{Ma}$ (Bowring et al. 2003).

The Playa Hermosa Formation is a deep-water correlate of the Las Ventanas Formation (Pazos et al. 2003; Rapalini et al. 2015). Its age is constrained between $594 \pm 16 \mathrm{Ma}$ (youngest detrital zircon U-Pb age) and $578 \pm 4 \mathrm{Ma}$ for intruding magmatic rocks (Rapalini et al. 2015), confirming its coeval deposition with respect to the Las Ventanas Formation. Glacially influenced deposits were also described from this unit (Pazos et al. 2003).

The Arroyo del Soldado Group (ASG) represents the drift stage after deposition of the rift deposits, comprising a marine platform succession exceeding $5,000 \mathrm{~m}$ in thickness. It rests unconformably on top of Archaean to Mesoproterozoic rocks of the Nico Pérez Terrane (Gaucher $2000,2014)$. In ascending stratigraphic order, the ASG is made up of the following formations (Gaucher 2000, 2014): Barriga Negra (conglomerates and sandstones), Yerbal (sandstones, shale, BIF, and minor dolostones), Polanco (carbonates), Cerro Espuelitas (shales, BIF, and chert), Cerros San Francisco (quartz-arenites), and Cerro Victoria (dolostones).

Detrital zircon U-Pb ages of the lower Barriga Negra Formation provide a maximum age constraint of $566 \pm 8 \mathrm{Ma}$ (Blanco et al. 2009). Cloudina riemkeae, index fossil of the late Ediacaran (Grant 1990; Gaucher \& Germs 2009), occurs in the upper Yerbal Formation and in the lower-middle Polanco Formation (Gaucher \& Poiré 2009a). Trace fossils assigned to Thalassinoidesisp were described from the Cerro Victoria Formation, showing that this unit is already Early Cambrian in age (Sprechmann et al. 2004). Thus, except for the Cerro Victoria Formation and possibly also the
Cerros San Francisco quartz-arenites, the age of the ASG is late Ediacaran.

Several chemostratigraphic studies were carried out in the ASG, including $\mathrm{C}, \mathrm{O}, \mathrm{Sr}, \mathrm{Cr}$, and $\mathrm{Nd}$ isotopes, iron speciation and REE analyses. We summarize in the following main findings of these studies.

Only scarce chemostratigraphic data are available for marls of the upper Barriga Negra Formation, $\delta^{13} \mathrm{C}$ varying between -5.5 and $-1.4 \%$ (Gaucher et al. 2004, this work). In the Yerbal Formation, $\delta^{13} \mathrm{C}$ values for interbedded dolostones are positive, increasing from 1.2 to $2.2 \%$ toward the top (Gaucher et al. 2004). These values may be interpreted as postdating those of the Barriga Negra Formation, which are all negative. $\delta^{53} \mathrm{Cr}$ values of ferruginous cherts and BIF yielded strongly positive values of up to 5\% SRM 979 (Frei et al. 2013), which are interpreted as reflecting oxygenic weathering in the source area. It is worth noting that these $\delta^{53} \mathrm{Cr}$ values are the highest so far obtained for iron formations (Frei et al. 2009).

Due to the pure and uninterrupted carbonates that compose the unit, the Polanco Formation represents a formidable chemostratigraphic archive (Fig. 26). Three positive $\delta^{13} \mathrm{C}$ excursions occur at the base $\left(\mathrm{P}_{1}\right)$, middle $\left(\mathrm{P}_{2}\right)$, and upper parts of the unit $\left(\mathrm{P}_{3}\right)$, reaching $5.5 \%, 2.1 \%$, and 4.1\%o, respectively (Gaucher et al. 2004, 2009; Frei et al. 2011; Fig. B). The intervening negative excursions coincide with regressions, the most prominent being $\mathrm{N}_{1}$, which encompasses $200 \mathrm{~m}$ of section and drops to nadir $\delta^{13} \mathrm{C}$ values of $-4.5 \%$ (Gaucher et al. 2004, 2009b). This negative excursion has been correlated with the Shuram-Wonoka anomaly (Gaucher et al. 2009b; Boggiani et al. 2010; Frei et al. 2011; Gaucher 2014), which ended just before $551 \pm 1 \mathrm{Ma}$ (Condon et al. 2005). The upper $\mathrm{N}_{2}$ negative excursion (-2\%o VPDB) marks the top of the Polanco Formation (Gaucher et al. 2004, 2009; Frei et al. 2011; Fig. 26).

Secular variations can be recognized in the ${ }^{87} \mathrm{Sr} /{ }^{86} \mathrm{Sr}$ curve of the Polanco Formation (Gaucher et al. 2009b; Frei et al. 2011; Gaucher 2014), which are relevant to determine the precise shape of the global Ediacaran ${ }^{87} \mathrm{Sr} /{ }^{66} \mathrm{Sr}$ curve. Limestones contain in average $1025 \mathrm{ppm} \mathrm{Sr}$, reaching more than 3000 ppm (Gaucher et al. 2009; Gaucher 2014). ${ }^{87} \mathrm{Sr} /{ }^{86} \mathrm{Sr}$ values of 0.7087 at the base of the Polanco Formation decrease steadily up section, reaching a plateau around 0.7070 in the middle part of the unit (Gaucher $e t a l$. 2009; Frei et al. 2011; Fig. 26). ${ }^{87} \mathrm{Sr} /{ }^{86} \mathrm{Sr}$ analyses are more erratic in the upper part of the unit, but it seems clear that there is a return to higher ratios of $0.7080-0.7085$ (Gaucher et al. 2009; Frei et al. 2011). The more than $300 \mathrm{~m}$ of section characterized by low ${ }^{87} \mathrm{Sr} /{ }^{86} \mathrm{Sr}$ values encompasses the $\mathrm{N}_{1}$ negative $\delta^{13} \mathrm{C}$ excursion. On the basis of elevated $\varepsilon \mathrm{Nd}(\mathrm{t})$ 
values in the same carbonates (Fig. 26), Frei et al. (2011) proposed that the fall of ${ }^{87} \mathrm{Sr} /{ }^{86} \mathrm{Sr}$ values may represent a distal hydrothermal signature caused by widespread rifting elsewhere. A similar pattern is observed between the late Triassic and Late Jurassic, when ${ }^{87} \mathrm{Sr} /{ }^{86} \mathrm{Sr}$ fell between more

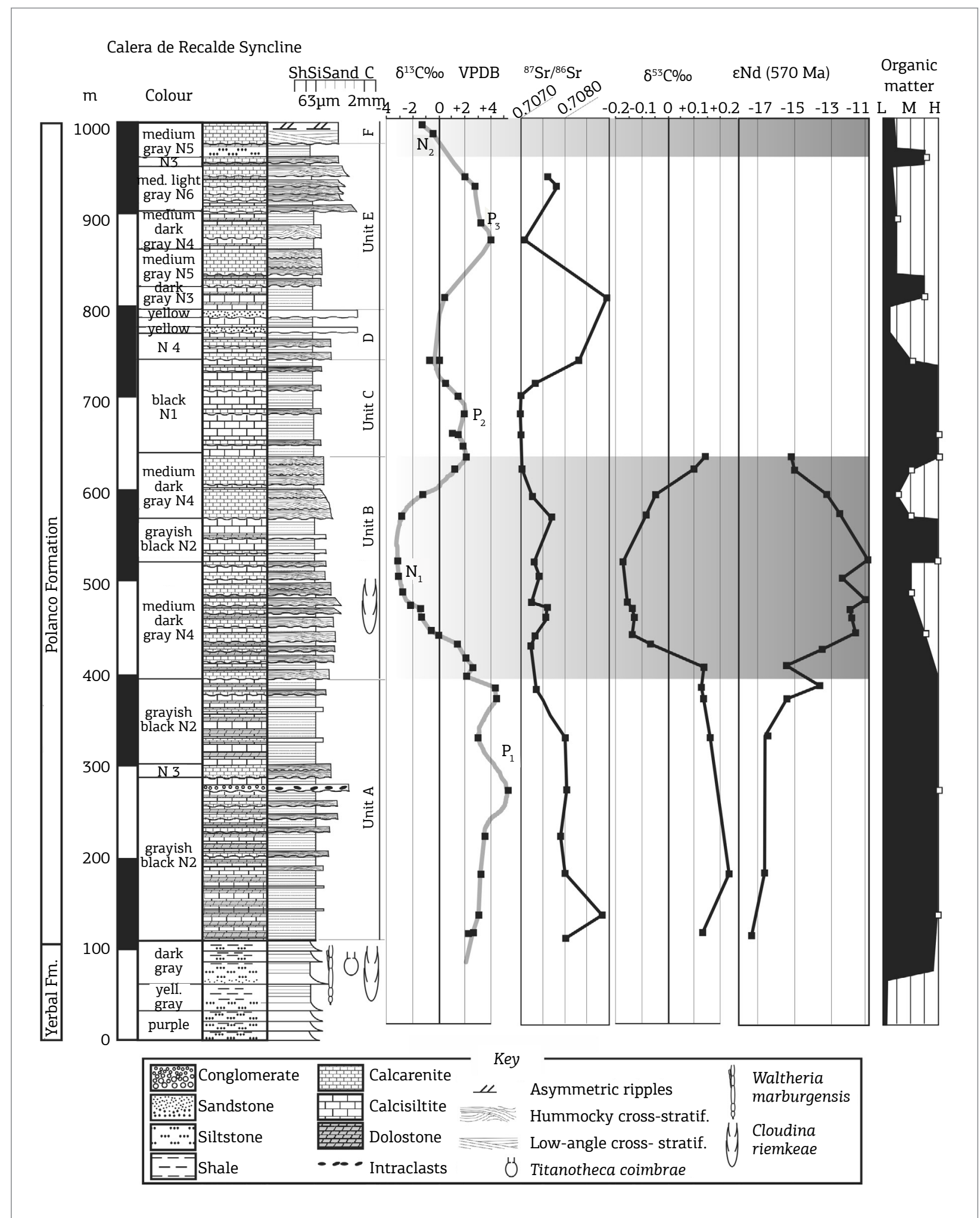

Figure 26. Stratigraphic column of the Polanco Formation at Calera de Recalde Syncline, showing $\varepsilon^{13} \mathrm{C},{ }^{87} \mathrm{Sr} /{ }^{86} \mathrm{Sr}$, $\varepsilon^{53} \mathrm{Cr}$ and $\varepsilon N d$ data. Modified from Gaucher et al. (2004, 2009b), Frei et al. (2011) and Gaucher (2014). 
than 0.7080 and 0.7068 (e.g. Veizer et al. 1999), related to the breakup of Pangaea.

Only minor carbonate interbeds occur in the overlying Cerro Espuelitas Formation, which yielded negative $\delta^{13} \mathrm{C}$ values, interpreted as a continuation of the $\mathrm{N}_{2}$ negative excursion of the upper Polanco Formation (Gaucher et al. 2004, 2009). Magnetite BIF of the same unit yielded positive $\delta^{53} \mathrm{Cr}$ values of up to 1.3\%o SRM 979 (Frei et al. 2013), thus lower than hematite-bearing BIF of the Yerbal Formation. At the top of the ASG, the Cerro Victoria Formation yielded a low-amplitude $\delta^{13} \mathrm{C}$ curve consistent with an earliest Cambrian age (Gaucher et al. 2007; Sprechmann et al. 2004).

Combined bio- and chemostratigraphic data enabled the correlation at the formational level between the Corumbá and Arroyo del Soldado Groups, and between the latter unit and the Sierras Bayas Group in Argentina (see below). These correlations (Fig. 27) suggest that an extensive carbonate platform covered the eastern RPC in the late Ediacaran and likely continued northwards into the Rio Apa Block (Gaucher et al. 2003, 2008a).

\section{Marco de los Reyes Formation (Uruguay)}

This unit was erected by Chiglino et al. (2010) to include a sedimentary succession occurring in the Nico Pérez Terrane and metamorphosed in the amphibolite facies. The unit comprises dark limestone, BIF, chert, and mica-schist. Limestones yielded $\delta^{13} \mathrm{C}$ values between 4.4 and $-3.2 \%$. Corresponding ${ }^{87} \mathrm{Sr} /{ }^{86} \mathrm{Sr}$ values consistently fall between 0.7070 and 0.7080 for high-Sr limestones (average: $1882 \mathrm{ppm}$; Chiglino et al. 2010). Given that both $\delta^{13} \mathrm{C}$ and ${ }^{87} \mathrm{Sr} /{ }^{86} \mathrm{Sr}$ fall within the range reported for the ASG, a correlation between both units seems probable (Chiglino et al. 2010; Bossi et al. 2014).

\section{Sierras Bayas Group (Argentina)}

The Sierras Bayas Group (SBG) occurs in the Tandilia range in Argentina (Fig. 25). It is an unmetamorphosed, flat-lying, marine sedimentary succession representing a cratonic cover (Poiré 1987; Poiré \& Gaucher 2009; Cingolani 2011 , and references therein). From base to top the following stratigraphic units are recognized (Fig. 27):

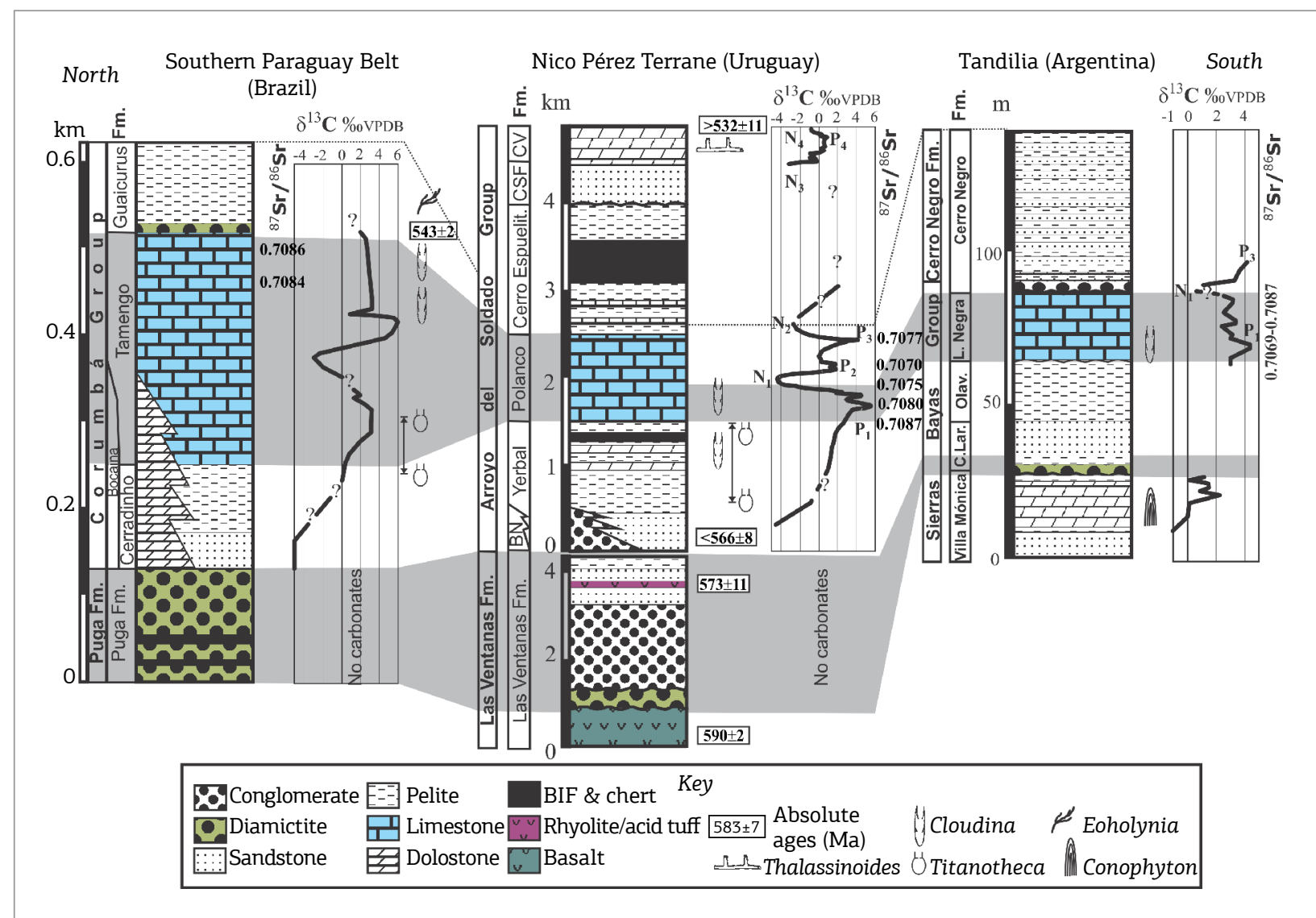

Figure 27. Stratigraphy and correlations of the ASG with the Corumbá Group in Brazil (Gaucher et al. 2003; Boggiani et al. 2010) and Sierras Bayas Group in Argentina (Gaucher et al. 2005; Poiré and Gaucher, 2009), as well as underlying glaciogenic units. Modified from Gaucher (2014). BN: Barriga Negra Fm. CSF: Cerros San Francisco Fm. CV: Cerro Victoria Fm. C.Lar.: Cerro Largo Fm. Olav.: Olavarría Fm. L. Negra: Loma Negra Fm. Sources of chemo- and biostratigraphic data and absolute ages: see text. 
1. Villa Mónica Formation: stromatolitic dolostones, minor phosphorite (Gómez-Peral et al. 2014).

2. Cerro Largo Formation: cross-bedded quartz-arenite and subordinated shale, with a distinct diamictite unit (Colombo Member) at the base (Poiré \& Gaucher 2009).

3. Olavarría Formation: shales, bearing low-diversity acritarchs (Gaucher et al. 2005).

4. Loma Negra Formation: Cloudina-bearing, finegrained limestones (Gaucher et al. 2005; Gaucher \& Poiré 2009a).

The Cerro Negro Formation (shales, sandstones, marls, and minor phosphorite) overlies the SBG with erosional unconformity (Gómez Peral et al. 2014, and references therein).

The Colombo diamictite may represent glacially influenced, rift-related deposits (Poiré \& Gaucher 2009; Gaucher \& Poiré 2009b) which can be correlated to diamictites of the Las Ventanas and Playa Hermosa formations in Uruguay. Rapalini et al. (2013) obtained similar paleopoles for both units, supporting this correlation.

Several chemostratigraphic studies were carried out in the SBG and Cerro Negro Formation. The Villa Mónica dolostones are characterized by rising $\delta^{13} \mathrm{C}$ values $(-2.2$ to $2.2 \%$ ) and ${ }^{87} \mathrm{Sr} /{ }^{86} \mathrm{Sr}$ between 0.7069 and 0.7071 (Fig. 27), although the primary nature of the latter remains to be proved (Gómez Peral et al. 2007, 2014). The age of the Villa Mónica Formation can so far be regarded as Neoproterozoic, but more analyses are needed to further constrain it.

The Loma Negra Formation is characterized by positive $\delta^{13} \mathrm{C}$ ratios, decreasing up-section from $4.5 \%$ o to near zero (Gómez Peral et al. 2007; Bagnoud-Velásquez et al. 2013). ${ }^{87} \mathrm{Sr} /{ }^{86} \mathrm{Sr}$ analyses in the same unit yielded ratios between 0.7069 and 0.7087 (Kawashita et al. 1999). Taken together, both $\mathrm{C}$ and $\mathrm{Sr}$ isotope values match those obtained for the lower Polanco Formation of the ASG (Fig. 27).

$\delta^{13}$ Corg in the Loma Negra Formation varies between -23 and $-28 \%$, with corresponding $\mathrm{D} \delta^{13} \mathrm{C}_{\text {car-org }}$ ranging between 25 and 32\%o (Gómez Peral et al. 2007; BagnoudVelásquez et al. 2013). This is interpreted as reflecting the original fractionation by oxygenic photoautotrophs (Bagnoud-Velásquez et al. 2013), which agrees with the reported eukaryotic microbiota dominated by Leiosphaeridia (Gaucher et al. 2005).

Reported $\delta^{34} S$ pyrite values $(24-32.5 \%$ o CDT) in the Loma Negra Formation are heavier than $\delta^{34} S_{\text {CAS }}$ for the same unit (24 - $29 \%$, Bagnoud-Velásquez et al. 2013). This "superheavy pyrites" have been interpreted for the coeval Nama Group (southern Africa) as the result of enhanced bacterial sulphate-reduction activity in a low sulphate environment, hinting at low atmospheric $\mathrm{O}_{2}$ contents in the latest Ediacaran (Ries et al. 2009).
As for the Cerro Negro Formation, basal phosphorites yielded negative $\delta^{13} \mathrm{C}$ values around -1\%o VPDB, steadily increasing in overlying marls to a maximum of $4.3 \%$. This latter positive excursion may match the $\mathrm{P}_{3}$ excursion of the upper Polanco Formation (4.1\%o). As a condensed succession deposited in a shallow-water setting, it is not surprising that in the SBG erosional unconformities mark the regressions recorded in the deeper-water ASG, most notably carbonates deposited during $\mathrm{N}_{1}$. Acritarchs of the Cerro Negro Formation suggest a late Ediacaran age for the unit (Cingolani et al. 1991; Gaucher et al. 2005).

\section{CHEMOSTRATIGRAPHIC CORRELATIONS: DISCUSSION AND CONCLUSIONS}

It is well known that fossils and $\mathrm{U}-\mathrm{Pb}$ ages are the most reliable tools in stratigraphic correlation of sedimentary successions. In this way, it is possible that the upper Itapucumí Group, Tamengo, upper Sete Lagoas, Loma Negra, and Polanco formations are all correlative because they host Cloudina and, therefore, could be of late Ediacaran age (ca. 560 - $541 \mathrm{Ma}$ ). The Frecheirinha Formation hosts an impoverished acritarch biota which points also to a late Ediacaran age.

Limited knowledge of absolute ages among some of the successions discussed in this study represents an obstacle in precise their stratigraphic correlation. U-Pb ages from detrital zircons have been used in cases when datable volcanic rocks are absent. This has led occassionaly to controversial interpretations when ages obtained this way are contrasted with those from other methods applied to same stratigraphic intervals. For example, $\mathrm{Pb}-\mathrm{Pb}$ model age for the Sete Lagoas Formation $(740 \pm 22 \mathrm{Ma})$ regarded as acceptable geochronological data until recently (Babinski et al. 2007) has been contested by U-Pb age of detrital zircon (610 Ma) from the same stratigraphic interval (Pimentel et al. 2011). Furthermore, the presence of Cloudina sp. in the the Sete Lagoas Formation suggests a late Ediacaran age, at least for exposures in central-eastern Brazil.

In the absence of fossils and/or radiometric age dating, elemental and isotope chemostratigraphy (e.g. Sr, C, S, Ca, $\mathrm{Cr}, \mathrm{Mo}, \mathrm{N}$ isotopes), in spite of limitations, may represent an important tool in stratigraphic correlation. Strontium isotope ratios $\left({ }^{87} \mathrm{Sr} /{ }^{86} \mathrm{Sr}\right)$ have been used with this purpose after its suggested monotone rise from Tonian through Cambrian has been proposed (e.g. Halverson et al. 2010). One cannot ignore, however, that large ${ }^{87} \mathrm{Sr} /{ }^{86} \mathrm{Sr}$ secular variations, within one same late Ediacaran succession, has been sometimes observed (e.g. from 0.7070 to 0.7087 in 
a 900-m-thick, high-Sr limestone section of the Polanco Formation, Uruguay) implying a severe limitation on its use as a stand-alone proxy. If one compares with the more detailed ${ }^{87} \mathrm{Sr} /{ }^{86} \mathrm{Sr}$ Phanerozoic record, characterized by strong ${ }^{87} \mathrm{Sr} /{ }^{86} \mathrm{Sr}$ oscillations (Veizer et al., 1999) the proposed monotone ${ }^{87} \mathrm{Sr} /{ }^{86} \mathrm{Sr}$ rise in the Neoproterozoic is likely an artifact of low sampling resolution.

A tentative correlation of the carbonate-dominated successions in this study, based on available ${ }^{87} \mathrm{Sr} /{ }^{86} \mathrm{Sr}$ and $\delta^{13} \mathrm{C}$ values, is shown in Table 1 . The ${ }^{87} \mathrm{Sr} /{ }^{86} \mathrm{Sr}$ ratios for pure carbonates of the Jucurutu Formation $(0.7074-0.7075)$ are equivalent to those found for the early Ediacaran Mirassol D'Oeste Formation in the Paraguay Belt, and Maieberg Formation, Otavi Group (Namibia). According to detrital zircons and intrusions the depositional age of the Jucurutu Formation should be between $634 \mathrm{Ma}$ (youngest zircon) and $591 \mathrm{Ma}$ (Totoró Granite). The Seridó Fm. is younger than $611 \pm 7 \mathrm{Ma}$.

From the ${ }^{87} \mathrm{Sr} /{ }^{86} \mathrm{Sr}$ ratios and $\delta^{13} \mathrm{C}$ compilation shown in Table 1, apparently the Cryogenian (circa 720 - 635 Ma; Shields-Zhou et al. 2016) is poorly represented among the examined carbonate-dominated successions, except for the Jacoca and Acaua formations, and the end-Cryogenian Palestina, Jequitaí, Bebedouro, and Puga glaciogenic diamictites. There is a possibility that the deposition of the Panelinhas and Cabravinha formations happened at the end-Cryogenian glaciation, but so far there is no radiometric constraint. Despite of the effort to precise the depositional age of rocks of the Bambuí and Una groups (U-Pb dating, ${ }^{87} \mathrm{Sr} /{ }^{86} \mathrm{Sr}$ ratios and $\delta^{13} \mathrm{C}$ and paleontological data), this is still a matter of strong debate, far from being settled. It cannot be totally discarded the possibility that the sedimentation of part of this group happened in the early-to-middle Cryogenian as shown in Table 1.

\section{ACKNOWLEDGMENTS}

We thank Prof. U. G. Cordani, editor-in-chief of the $\mathrm{BJG}$, for the invitation to review the use of chemostratigraphy in the correlation of Neoproterozoic carbonate-dominated successions in South America. This paper aims at the celebration of the 25th anniversary (September 2015) of the Stable Isotope Laboratory (LABISE) of the Federal University of Pernambuco (UFPE), Recife, Brazil. ANS thanks the continuous financial support received from CNPq (470399/2008, 472842/2010-2, 471036/2012-9) and FACEPE (APQ-0388-1.08/10). PCB thanks the financial support from FAPESP (Proc. 04/01233-0 and 2010/02677$0)$. His scientific contribution to this manuscript is tied to the IGCP 478 project (Neoproterozoic-Early Palaeozoic Events in southwestern Gondwana). LVW also thanks the financial support from CNPq (Proc. 444070/2014-1) and FAPESP (Proc. 2015/24608-3). This is the contribution n. 276 of the NEG-LABISE.

\section{REFERENCES}

Abre P., Bossi J., Cingolani C., Gaucher C., Piñeyro D., Blanco G. 2014. El Terreno Tandilia en Uruguay y Argentina. In: Bossi J. \& Gaucher C. (eds.). Geología del Uruguay. Tomo 1: Predevónico. Montevideo, Polo, pp. 89-119.

Allen P.A. \& Etienne J.L. 2008. Sedimentary challenge to Snowball Earth. Nature Geoscience, 1:817-825.

Almeida F.F.M. 1965. Geologia da Serra da Bodoquena (Mato Grosso), Brasil. Boletim da Divisão de Geologia e Mineralogia, DNPM, Rio de Janeiro, 216, 96 pp.

Alkmim F.F., Chemale F. Jr., Endo I. 1996. A deformacão das coberturas proterozoicas do Craton do São Francisco e o seu significado tectônico. Revista da Escola de Minas de Ouro Preto, 49:22-38.

Alkmim F.F., Martins-Neto M.A. 2001. A Bacia intracratônica do São Francisco: arcabouço estrutural e cenários evolutivos. In: Pinto, C.P., Martins-Neto M.A. (Orgs.). Bacia do São Francisco: geologia e recursos minerais. Belo Horizonte: Sociedade Brasileira de Geologia, pp 9-30.

Andrade Filho E.L., Neves J.P., Guimarães J.T. 1994. Santa Rita de Cássia (Folha SC.23-Z-C) e Formosa do Rio Preto (Folha SC.23-Y-D). Programa Levantamentos Geológicos Básicos do Brasil, Serviço Geológico do Brasil. Brasília, 50 pp.
Angelim L.A.A., Medeiros V.C., Nesi J.R. 2006. Mapa Geológico do Estado do Rio Grande do Norte. Programa Geologia do Brasil. Projeto Mapa Geológico e de Recursos Minerais do Estado do Rio Grande do Norte. Recife: CPRM/FAPERN, 2006.

Alvarenga C.J.S., Boggiani P.C., Babinski M, Dardenne M.A., Figueiredo M.F., Dantas E.L., Uhlein A., Santos R.V., Sial A.N., Trompette R. 2011. Glacially influenced sedimentation of the Puga Formation, Cuiabá Group and Jacadigo Group, and associates carbonates of the Araras and Corumbá groups, Paraguay Belt, Brazil. In Arnaud E., Halverson G.P., Shields-Zhou G. (eds.). The Geologiacal Record of Neoproterozoic Glaciations. Geological Society, London, Memoirs, 36:487-497.

Alvarenga C.J.S., Dardenne M.A., Santos R.V., Brod E.R., Gioia S.M.C.L., Sial A.N., Dantas E.L., Ferreira V.P. 2008. Isotope stratigraphy of Neoproterozoic cap carbonates in the Araras Group, Brazil. Gondwana Research, 13:469-479.

Alvarenga C.J.S., Della Giustina M.E., Silva N.G.C., Santos R.V., Gioia S.M.C.L., Guimarães E.M., Dardenne M.A., Sial A.N., Ferreira, V.P. 2007. Variações dos isótopos de C e Sr em carbonatos pré e pósglaciação Jequitaí (Esturtiana) na região de Bezerra-Formosa, Goiás. Revista Brasileira de Geociências, 37(4):147-155. 
Alvarenga C.J.S., Santos R.V., Dantas E.L. 2004. C-O-Sr isotopic stratigraphy of cap carbonates overlying Marinoan-age glacial diamictites in the Paraguay Belt, Brazil. Precambrian Research, 131:1-21.

Alvarenga C.J.S., Boggiani P.C., Babinski M., Dardenne M.A., Figueiredo M.F., Santos R.V., and Dantas, E.L., 2009, The Amazonian Paleocontinent. In: Gaucher C., Sial A.N., Halverson G.P., Frimmel H.E. (eds.). Neoproterozoic-Cambrian tectonics, global change and evolution: a focus on Southwestern Gondwana: Developments in Precambrian Geology. Amsterdam, Elsevier, 16:15-28.

Alvarenga C.J.S., Santos R.V., Vieira L.C., Lima B.A.F., Mancini L.H 2014. Meso-Neoproterozoic isotope stratigraphy on carbonates platforms in the Brasilia Belt of Brazil. Precambrian Research, 251:164-180.

Archanjo C.J., Viegas L.G., Hollanda M.H.B.M., Souza L.C., Liu D. 2013. Timing of the HT/LP transpression in the Neoproterozoic Serido Belt (Borborema Province, Brazil): constraints from U-Pb (SHRIMP) geochronology and implications for the connections between NE Brazil and West Africa. Gondwana Research, 23(2):701-714.

Avila Salinas W.A. 1992. El magmatismo Cámbrico-Ordovícico en Bolivia. In: Gutierrez-Marco J.G., Saavedra J., Rabano, I. (eds.) Paleozoico Inferior de Iberoamérica. Universidad de Extremadura, Mérida, pp. 241-253

Babinski M., Boggiani P.C., Fanning C.M., Fairchild T.R., Simon C.M., Sial A.N. 2008. On Isotope Geology U-Pb SHRIMP geochronology and isotope chemostratigraphy $(\mathrm{C}, \mathrm{O}, \mathrm{Sr})$ of the Tamengo Formation, Southern Paraguay Belt, Brazil. In: Linares E., Cabaleri N.G., do Campo M.D., Ducós E.I., Panarello H.O. (eds.). Proceedings of VI South American Symposium. Buenos Aires: CD-ROM.

Babinski M., Boggiani P.C., Trindade R.I.F., Fanning C.M. 2013. Detrital zircon ages and geochronological constraints on the Neoproterozoic Puga diamictites and associated BIFs in the southern Paraguay Belt, Brazil. Gondwana Research, 23:988-997.

Babinski M., Vieira, L.C., Trindade R.I.F. 2007. Direct dating of the Sete Lagoas cap carbonate (Bambuí Group, Brazil) and implications for the Neoproterozoic glacial events. Terra Nova, 19(6):401-406

Bagnoud-Velásquez M., Spangenberg J.E., Poiré D.G., Gómez-Peral L.E. 2013. Stable isotopes (C, S) and hydrocarbon biomarkers in Neoproterozoic sediments of the upper section of Sierras Bayas Group, Argentina. Precambrian Research, 231:340-388.

Barroso F.R.G., Viana M.S.S., Lima Filho M.F., Agostinho S.M.O. 2014 First Ediacaran fauna occurrence in Northeastern Brazil (Jaibaras Basin, Ediacaran-Cambrian): preliminary results and regional correlation. Anais da Academia Brasileira de Ciências, 86:1029-1042.

Bekker A., Sial A.N., Karhu J.A., Ferreira V.P., Noce C.M., Kaufman A.J., Romano A.W., Pimentel M.M. 2003. Chemostratigraphy of carbonates from the Minas Supergroup, Quadrilátero Ferrifero (Iron Quadrangle), Brazil: A stratigraphic record of early Proterozoic atmospheric, biogeochemical and climatic change. American Journal of Science, 303:865-904.

Berger A. \& Frei R. 2013. The fate of chromium during tropical weathering: A laterite profile from Central Madagascar. Geoderma, 213:521-532.

Blanco G. \& Gaucher C. 2005. Estratigrafia, paleontologia y edad de la Formacion Las Ventanas (Neoproterozoico, Uruguay). Latin American Journal of Sedimentology and Basin Analysis, 12(2):109-124.

Blanco G. \& Gaucher, C. 2014. Formación Las Ventanas. In: Bossi J. \& Gaucher C. (eds.). Geología del Uruguay. Tomo 1. Predevónico. Polo, Montevideo, pp. 299-312.

Blanco G., Rajesh H.M., Gaucher C., Germs G.J.B., Chemale Jr., F. 2009. Provenance of the Arroyo del Soldado Group (Ediacaran to Cambrian, Uruguay): Implications for the paleogeographic evolution of southwestern Gondwana. Precambrian Research, 171:57-73.
Boggiani P.C. 1998. Análise Estratigráfica da Bacia Corumbá (Neoproterozóico), Mato Grosso do Sul. Tese de Doutorado, Instituto de Geociências, Universidade de São Paulo, São Paulo, 181p.

Boggiani P.C., Coimbra A.M., Sial A.N., Ferreira V.P. 1996. Incursão positiva de delta $13 \mathrm{C}$ (Ediacarana) na Formação Tamengo, Grupo Corumbá (Neoproterozóico). In: 39 Congresso Brasileiro de Geologia, Anais... Salvador, pp. 570-572.

Boggiani P.C., Fairchild T.R., Coimbra A. M. 1993. O Grupo Corumbá (Neoproterozóico-Cambriano) na região Central da Serra da Bodoquena (Faixa Paraguai), Mato Grosso do Sul. Revista Brasileira de Geociências, 23(3):301-305.

Boggiani P.C., Ferreira V.P, Sial A.N., Babinki M., Trindade R.I.F., Aceñolaza G., Toselli A.J., Parada M.A. 2003. The cap carbonate of the Puga Hill (Central South America) in the context of the postVaranger Glaciation. In: IV South American Symposium on Isotope Geology, Short Papers, Salvador, pp. 324-327.

Boggiani, P.C., Gaucher, C., 2004. Cloudina from the Itapucumí Group (Vendian, Paraguay): age and correlations. $1^{\text {st }}$ Symposium on Neoproterozoic-Early Palaeozoic Events in SW-Gondwana, Extended Abstracts, São Paulo, pp. 13-15.

Boggiani P.C., Gaucher C., Sial A.N., Babinski M., Simon C.M. Riccomini C., Ferreira V.P., Fairchild T.R. 2010. Chemostratigraphy of the Tamengo Formation (Corumbá Group, Brazil): A contribution to the calibration of the Ediacaran carbon-isotope curve. Precambrian Research, 182(4):382-401.

Bonnand P., James R.H., Parkinson I.J., Connelly D.P., Fairchild I.J. 2013. The chromium isotopic composition of seawater and marine carbonates. Earth Planetary Sciences Letters, 382:10-20.

Bossi J., Cingolani C.A. 2009. Extension and general evolution of the Río de la Plata Craton. In: Gaucher C., Sial A.N., Halverson G.P., Frimmel H.E. (eds.). Neoproterozoic-Cambrian tectonics, global change and evolution: a focus on southwest Gondwana: Developments in Precambrian Geology, Amsterdam, Elsevier, 16:73-85.

Bossi J., Gaucher C., Chiglino L., Navarro R., Piñeyro D. 2014. Escama Tectónica Carapé. In: Bossi, J., Gaucher, C. (eds). Geología del Uruguay. Tomo 1: Predevónico, Montevideo, Polo, pp. 265-282.

Bowring S., Myrow P., Landing E., Ramezani J., Grotzinger J. 2003. Geochronological constraints on terminal Neoproterozoic events and the rise of metazoans. Geophysical Research Abstracts, 5:13219.

Brito Neves B.B. \& Cordani U.G. 1991. Tectonic evolution of South America during the Late Proterozoic. In: Stern R.J. \& Van Schmus W.R. (eds.). Crustal Evolution in the Late Proterozoic. Precambrian Research, 53:23-40.

Brito Neves B.B., Sial A.N., Albuquerque J.P.T. 1977. Vergência centrífiga residual no Sistema de Dobramentos Sergipano. Revista Brasileira de Geociências, 7:102-114.

Caby R., Arthaud M.H., Archanjo C.J. 1995. Lithostratigraphy and petrostructural characterization of supracrustal units in the Brasiliano belts of Northeast Brazil: geodynamic implications. Journal of South American Earth Sciences, 8:235-246.

Calver C.R., Black L.P., Everard J.L., Seymour D.B. 2004. U-Pb zircon age constraints on late Neoproterozoic glaciation in Tasmania. Geology, 32(1):892-896.

Campanha G.A.C., Warren L.V., Boggiani P.C., Grohmann C.H., Cáceres A.A. 2010. Structural analysis of the Itapucumí Group in the Vallemí region, northern Paraguay: evidence of a new Brasiliano/Pan-African mobile belt. Journal of South American Earth Sciences, 30:1-11.

Caxito F.A., Halverson G.P., Uhlein A., Ross S. Dias T.G., Uhlein G.J. 2012. Marinoan glaciation in east central Brazil. Precambrian Research, 200-203:38-58. 
Cezario W.S 2011 Quimioestratigrafia Isotópica (C, O e Sr) em duas capas carbonáticas Neoproterozoicas, Bacia do Rio Pardo e Cinturão Rio Preto, Bahia, Nordeste do Brasil. Tese de Mestrado, Universidade Federal de Pernambuco, Recife, 129 pp.

Cezario W.S., Sial A.N., Misi A., Pedreira A.J., Gaucher C., Ferreira V.P., Lacerda, L.D. 2011. Carbon-isotope and Hg stratigraphies of the Neoproterozoic Serra do Paraíso (Rio Pardo Basin) and São Desiderio (Rio Preto Belt) formations, Bahia, Brazil. In: XIII Congresso Brasileiro de Geoquímica, Anais... Gramado, pp. 1163-1166.

Chamot G.A. 1963. Esquisse geologique de la plateforme du Bouclier Brésilien dans l'Oriente des Chiquitos (Bolivie). Eclogae Geologicae Helvetiae, 56(2):817-852.

Chang K.H. 1997. Isótopos estáveis (C, H, O) e ${ }^{87} \mathrm{Sr} /{ }^{86} \mathrm{Sr}$ : implicações na estratigrafia e na paleocirculação de fluidos na Bacia do São Francisco. Tese de Livre-Docência, Instituto de Geociências e Ciências Exatas, UNESP, Rio Claro, 129 pp.

Chang K.H., Kawashita K., Zaine M.F. 1994. Isotopic composition of carbonates from late Proterozoic sucessions in Brazil and their stratigraphic variations. In: International Sedimentological Congress, 14, Abstracts. Recife: IAS, pp. G-21

Chiglino L. 2013. Quimiestratigrafía e Biostratigrafía da Formação Frecheirinha (Grupo Ubajara), Nordeste do Brasil. Tese de doutorado, Universidade Federal de Pernambuco, Recife, 101 pp.

Chiglino L., Gaucher C., Sial A.N., Bossi J., Ferreira V.P., Pimentel M.M. 2010. Chemostratigraphy of Mesoproterozoic and Neoproterozoic carbonates of the Nico Pérez Terrane, Río de la Plata Craton, Uruguay. Precambrian Research, 182(4):313-336.

Chiglino L., Gaucher C., Sial A.N., Ferreira V.P. 2015. Acritarchs of the Ediacaran Frecheirinha Formation, Ubajara Group, Northeastern Brazil. Anais da Academia Brasileira de Ciências, 87(2):635-649.

Cingolani C. 2011. The Tandilia System of Argentina as a southern extension of the Río de la Plata craton: an overview. International Journal of Earth Sciences 100(2): 221-242.

Cingolani C.A., Rauscher R., Bonhomme M., 1991. Grupo La Tinta (Precámbrico y Paleozoico Inferior), provincia de Buenos Aires, Argentina: Nuevos datos geocronológicos y micropaleontológicos en las sedimentitas de Villa Cacique, partido de Juárez. Revista Técnica de YPFB, 12(2):177-191.

Condon D., Zhu M., Bowring S., Jin Y., Wang W., Yang A. 2005. U-Pb ages from the Doushantuo Formation, China. Science, 308:95-98.

Corsetti F.A.\& Kaufman A.J. 2003. Stratigraphic investigations of carbon isotope anomalies and Neoproterozoic ice ages in Death Valley, California. Geological Society of America Bulletin, 115(8):916-932.

Costa Pinto N.M. 1977. Determinações isotópicas de carbono e oxigênio em rochas metassedimentares do Grupo Rio Pardo, Bahia. Dissertação de Mestrado, Universidade Federal da Bahia, Salvador, 61 p.

Crowe S.A., Døssing L.N., Beukes N.J., Bau M., Kruger S.J., Frei R., Canfield D.E. 2013. Atmospheric oxygenation three billion years ago. Nature, 501:535-538.

Dardenne, M.A., 1978. Síntese sobre a estratigrafia do Grupo Bambuí no Brasil Central. In: XXX Congresso Brasileiro de Geologia, Anais... Recife: Sociedade Brasileira de Geologia, pp. 597-610.

Dardenne, M.A., 1979. Les minéralisations de plomb, zinc, fluor du Protérozoïque Supérieur dans le Brésil Central. Tese de Doutorado, Université de Paris VI, 251 pp.

Dardenne M.A 2000. The Brasilia fold belt. In: Cordani, U.G., Milani, E.J., Thomaz Filho, A., Campos, D.A. (eds.) Tectonic Evolution of South America. Rio de Janeiro: 31st International Geological Congress, pp. 231-263.
Dardenne M.A. 2001. Lithostratigraphic sedimentary sequence of the Vazante Group. In: Misi, A. \& Teixeira, J.B.G. (orgs.). Proterozoic base metal deposits of Africa and South America. Proceedings of the I Field Workshop IGCP 450, CNPq/UNESCO/IUGS, Belo Horizonte and Paracatu, pp. 48-50.

Davison I. \& Santos R.A. 1989. Tectonic evolution of the Sergipano Fold, NE Brazil, during the Brasiliano Orogeny. Precambrian Research, 45(4):319-342.

D'el Rey Silva L.J.H. 1995. The evolution of basement gneiss domes of the Sergipano fold belt (NE Brazil) and its importance for the analysis of Proterozoic basins. Journal of South American Earth Sciences, 8:325-340.

D’el Rey Silva L.J.H. 1999. Basin infilling in the southern-central part of the Sergipano Belt (NE Brazil) and implications for the evolution of Pan-African/ Brasiliano cratons and Neoproterozoic sedimentary cover. Journal of South Amerian Earth Sciences, 12:453-470.

Derry L.A., Kaufman A.J., Jacobsen S.B. 1992. Sedimentary cycling and environmental change in the Late Proterozoic: evidence from stable and radiogenic isotopes. Geochimica et Cosmochimica Acta, 59(3):1317-1329.

Døssing L.N., Gaucher C., Boggiani P.C., Frei R. 2010. Stable Chromium Isotopes as tracer of changes in weathering processes and redox state of the ocean during Neoproterozoic glaciation. American Geophysical Union, Fall Meeting, San Francisco.

Egydio-Silva M. 1987. Sistema de dobramentos Rio Preto e suas relações com o Craton do São Francisco. Tese de Doutorado, Instituto de Geociências, Universidade de São Paulo, 141 pp.

Egydio-Silva M., Karmann I., Trompette R.1989. Litoestratigrafia do Supergrupo Espinhaço e Grupo Bambuí no noroeste do Estado da Bahia. Revista Brasileira de Geociências, 19(2):141-152.

Fedonkin M.A., Simonetta A., Ivantsov A.Y. 2007. New data on Kimberella, the Vendian mollusc-like organism (White Sea region, Russia): palaeoecological and evolutionary implications. In: VickersRich, P. And Komarower, P. (eds.) The Rise and Fall of the Ediacara Biota. Geological Society, London, Special Publication, 286:157-179.

Fernández-Ramírez R., Vargas-Mattos G., Matos R., Geraldes M.C., Sial A.N. 2009. Isótopos de C em carbonatos Neoproterozóicos da Bacia Tucavaca, Grupo Murciélago, Bolívia. XII Congresso Brasileiro de Geoquímica, Ouro Preto, Minas Gerais (CD-ROM).

Fetter A.H., Santos T.J.S., Van Schmus W.R., Hackspacher P.C., Brito Neves B.B., Arthaud M.H., Nogueira Neto J.A., Wernick E. 2003. Evidence for neoproterozoic continental arc magmatism in the Santa Quitéria Batholith of Ceará State, NW Borborema Province, NE Brazil: implications for the assembly of West Gondwana. Gondwana Research, 6:265-273.

Figueiredo M.F. 2006. Quimioestratigrafia das rochas ediacaranas no extremo norte da Faixa Paraguai, Mato Grosso. Dissertação de Mestrado, Instituto de Geociências, Universidade de São Paulo, Brazil.

Figueiredo F.T., Almeida R.P., Tohver E., Babinski M., Liu D. and Fanning C.M. 2009. Neoproterozoic glacial dynamics revealed by provenance of diamictites of the Bebedouro Formation, São Francisco Craton, Central Eastern Brazil. Terra Nova, 21(5):375-385.

Fölling P.G., Frimmel H.E. 2002. Chemostratigraphic correlation of carbonate succesions in the Gariep and Saldania Belts, Namibia and South Africa. Basin Research, 13:1-37.

Font, E., Nédélec A., Trindade R.I.F., Macouin M., Charrière, A. 2006. Chemostratigraphy of the Neoproterozoic Mirassol d'Oeste cap dolostone (Mato Grosso, Brazil): an alternative model for Marinoan cap dolostone formation. Earth and Planetary Science Letters, 250:89-103. 
Fontaneta G.T. 2012. Dolomitização e fosfogênese da Formação Bocaina: Grupo Corumbá (Ediacarano). Dissertação de Mestrado, Instituto de Geociências, Universidade de São Paulo, 148 p.

Fraga L.M.S., Neves S.C., Uhlein A., Sial A.N., Pimentel M.M., Horn A.F. 2014. C-, Sr-isotope stratigraphy of carbonate rocks from the Southern Espinhaço Ridge, Minas Gerais, southeastern Brazil. Anais da Academia Brasileira de Ciências, 86:633-648.

Frei R., Gaucher C., Poulton S.W., Canfield D.E. 2009. Fluctuations in Precambrian atmospheric oxygenation recorded by chromium isotopes. Nature, 461:250-254

Frei R., Gaucher C., Døssing L.N., Sial A.N., 2011. Chromium isotopes in carbonates - A tracer for climate change and for reconstructing the redox state of ancient seawater. Earth and Planetary Science Letters, 312,114-125.

Frei R., Gaucher C., Stolper D., Canfield, D.E., 2013. Fluctuations in late Neoproterozoic atmospheric oxidation - $\mathrm{Cr}$ isotope chemostratigraphy and iron speciation of the late Ediacaran lower Arroyo del Soldado Group (Uruguay). Gondwana Research, 23(2):797-811

Frei R. \& Polat A. 2012. Chromium isotope fractionation during oxidative weathering: implications from the study of a Paleoproterozoic (ca. 1.9 Ga) paleosol, Schreiber Beach, Ontario, Canada. Precambrian Research, 224:434-453.

Freitas B.T., Warren L.V., Boggiani P.C., Almeida R.P., Piacentini T. 2011. Tectono-sedimentary evolution of the Neoproterozoic BIFbearing Jacadigo Group, SW-Brazil. Sedimentary Geology, 238:48-70.

Galindo C., Casquet C., Rapela C., Pankhurst R.J., Baldo E., Saavedra J. 2004. Sr, C and O isotope geochemistry and stratigraphy of Precambrian and lower Paleozoic carbonate sequences from the Western Sierras Pampeanas of Argentina: tectonic implications. Precambrian Research, 131:55-71.

Gaucher C. 1999. Sedimentology, palaeontology and stratigraphy of the Arroyo del Soldado Group (Vendian to Cambrian, Uruguay). Ph.D. Thesis, Philipps-Univesität Marburg, Germany.

Gaucher C. 2000. Sedimentology, palaeontology and stratigraphy of the Arroyo del Soldado Group (Vendian to Cambrian, Uruguay). Beringeria, 26: 1-120.

Gaucher C. 2014. Grupo Arroyo del Soldado. In: Bossi, J., Gaucher, C. (eds.). Geología del Uruguay. Tomo 1: Predevónico, Montevideo, Polo, pp. 313-339.

Gaucher C. \& Sprechmann P. 1999. Upper Vendian skeletal fauna of the Arroyo del Soldado Group, Uruguay. Beringeria, 23:55-91.

Gaucher C.\& Germs G.J.B. 2009. Skeletonised metazoans and protists. Neoproterozoic-Cambrian biota. In: Gaucher C., Sial A.N., Halverson G.P., Frimmel H.E. (eds.). Neoproterozoic-Cambrian tectonics, global change and evolution: a focus on southwest Gondwana. Developments in Precambrian Geology, Amsterdam, Elsevier, 16:327-338.

Gaucher C.\& Poiré D. 2009a. Biostratigraphy. NeoproterozoicCambrian evolution of the Río de la Plata Palaeocontinent. In: Gaucher C., Sial A.N., Halverson G.P., Frimmel H.E. (eds.). Neoproterozoic-Cambrian tectonics, global change and evolution: a focus on southwest Gondwana. Developments in Precambrian Geology, Amsterdam, Elsevier, 16:103-114.

Gaucher C. \& Poiré D.G. 2009b. Palaeoclimatic events. NeoproterozoicCambrian evolution of the Río de la Plata Palaeocontinent. In: Gaucher C., Sial A.N., Halverson G.P., Frimmel H.E., eds., Neoproterozoic-Cambrian tectonics, global change and evolution: a focus on southwest Gondwana. Developments in Precambrian Geology, Amsterdam, Elsevier, 16:123-130.
Gaucher C., Boggiani P.C., Sprechmann P., Sial A.N., Fairchild T.R. 2003. Integrated correlation of Vendian to Cambrian Arroyo del Soldado and Corumbá Groups (Uruguay and Brazil): palaeogeographic, palaeoclimatic and palaeobiologic implications. Precambrian Research, 120:241-278.

Gaucher C., Sial A.N., Blanco G., Sprechmann P. 2004 Chemostratigraphy of the lower Arroyo del Soldado Group (Vendian, Uruguay) and palaeoclimatic implications. Gondwana Research, 7(3):715-730.

Gaucher C. Poiré D.G. Gómez Peral L.. Chiglino L. 2005. Litoestratigrafía, bioestratigrafía y correlaciones de las sucesiones sedimentarias del Neoproterozoico-Cámbrico del Cratón del Río de la Plata (Uruguay y Argentina). Latin American Journal of Sedimentology and Basin Analysis, 12(2):145-160.

Gaucher C., Sial A.N., Ferreira V.P., Pimentel M.M, Chiglino L., Sprechmann P. 2007. Chemostratigraphy of the Cerro Victoria Formation (Lower Cambrian, Uruguay): evidence for progressive climate stabilization across the Precambrian-Cambrian boundary. Chemical Geology, 237:28-46.

Gaucher C., Finney S.C., Poiré D.G., Valencia V.A., Grove M., Blanco G., Pamoukaghlián K., Gómez Peral, L. 2008a. Detrital zircon ages of Neoproterozoic sedimentary successions in Uruguay and Argentina: insights into the geological evolution of the Río de la Plata Craton. Precambrian Research, 167:150170.

Gaucher C., Blanco G., Chiglino L., Poiré D.G., Germs G.J.B. 2008b. Acritarchs of Las Ventanas Formation (Ediacaran, Uruguay): implications for the timing of coeval rifting and glacial events in western Gondwana. Gondwana Research, 13(4):488-501.

Gaucher G., Frimmel H.E., Germs G.J.B. 2009a. Tectonic Events and Palaeogeographic Evolution of Southwestern Gondwana in the Neoproterozoic and Cambrian. In: Gaucher C., Sial A.N., Halverson G.P., Frimmel H.E. (eds.). Neoproterozoic-Cambrian tectonics, global change and evolution: a focus on southwest Gondwana. Developments in Precambrian Geology, Amsterdam, Elsevier, 16:295-316.

Gaucher C., Sial A.N., Poiré D., Gómez-Peral L., Ferreira V.P., Pimentel M.M. 2009b. Neoproterozoic-Cambrian evolution of the Río de la Plata Palaeocontinent. Chemostratigraphy. In: Gaucher C., Sial A.N., Halverson G.P., Frimmel H.E. (eds.). Neoproterozoic-Cambrian tectonics, global change and evolution: a focus on southwest Gondwana. Developments in Precambrian Geology, Amsterdam, Elsevier, 16:115-122

Gaucher C., Sial A.N., Frei R. 2015. Chemostratigraphy of Neoproterozoic banded iron formation (BIF): types, age and origin In: Ramkumar M. (ed.). Chemostratigraphy, Concepts, Techniques and Applications, Elsevier, 433-449.

Gómez Peral, L.E., Poiré D.G., Strauss H., Zimmermann U. 2007 Chemostratigraphy and diagenetic constraints on Neoproterozoic carbonate successions from the Sierras Bayas Group, Tandilia System, Argentina. Chemical Geology, 237:109-128.

Gómez Peral L.E., Kaufman A.J., Poiré D.G. 2014. Paleoenvironmental implications of two phosphogenic events in Neoproterozoic sedimentary successions of the Tandilia System, Argentina. Precambrian Research, 252:88-106.

Grant S.W.F. 1990. Shell structure and distribution of Cloudina, a potential index fossil for the terminal Proterozoic. American Journal of Science, 290-A:261-294.

Grotzinger J.P., Bowring S.A., Saylor B.Z., Kaufman A.J. 1995 Biostratigraphic and geochronologic constraints on early animal evolution. Science, 270:598-604.

Halverson G.P., Hoffman P.F., Schrag D.P., Maloof A.C., Rice A.H.N 2005. Toward a Neoproterozoic composite carbon-isotope record. Geological Society of America Bulletin, 117:1181-1207. 
Halverson G.P., Dudas F.O., Maloof A.C., Bowring S.A. 2007. Evolution of the ${ }^{87} \mathrm{Sr} /{ }^{86} \mathrm{Sr}$ composition of the Neoproterozoic seawater. Paleogeography, Paleoclimatology, Paleoecology, 526:103-129.

Halverson G.P., Wade B.P., Hurtgen M.T., Barovich K.M. 2010. Neoproterozoic chemostratigraphy. Precambrian Research, 182(4):337-350.

Hess W.A. 1959. Chiquitos exploration. Geological Progress Report, Bolivian Gulf Oil Company, Santa Cruz, n. 54 (unpublished).

Hoffman P.F. 2011. Strange bedfellows: glacial diamictite and cap carbonate from the Marinoan (635 Ma) glaciation in Namíbia. Sedimentology, 58(1):57-119

Hoffman P.F. \& Schrag D.P. 2002. The Snowball Earth hypothesis: testing the limits of global change. Terra Nova, 14(3):129-155.

Hollanda M.H., Archanjo C.J. Souza L.C. 2010. Historia de proveniência do Grupo Seridó (Província Borborema), com base em dados isotópicos. Congresso Brasileiro de Geologia, Belém, (CD-ROM).

Hollanda H.B.M., Archanjo C.J., Bautista J.R., Souza L.C. 2015. Detrital zircon ages and Nd isotope compositions of the Seridó and Lavras da Mangabeira basins (Borborema Province, NE Brazil): evidence for exhumation and recycling associated with a major shift in sedimentary provenance. Precambrian Research, 258:186-207.

Holser W.T. 1997. Geochemical events documented in inorganic carbon isotopes. Palaeogeography, Palaeoclimatology, Palaeoecology, 132:173-182.

Humphrey F.L. \& Allard G.O. 1968. The Propriá geosyncline, a newly recognized Precambrian tectonic province in the Brazilian shield. Abstracts XXIII, International Geological Congress, Prague, 4, pp. 123-139.

Humphrey F.L. \& Allard G.O. 1969. Geologia da area do domo de Itabaiana (Sergipe) e sua relação com a geologia de Propriá: um elemento tectônico recém-reconhecido no escudo brasileiro. Petrobras, Centro de Pesquisa e Desenvolvimento (CENPES), Rio de Janeiro, Brazil, 159 p.

Jacobsen S.B., Kaufman A.J. 1999. The Sr, C and O isotopic evolution of Neoproterozoic seawater. Chemical Geology, 161:37-57.

Jardim de Sá E.F. 1994. A faixa Seridó (Província Borborema, NE do Brasil) e o seu significado geodinâmico na cadeia Brasiliana/Panafricana. Tese de Doutorado, Instituto de Geociências, Universidade de Brasilia, 804 p.

Jardim de Sá E.F., Salim J. 1980. Reavaliação dos conceitos estratigráficos na região do Seridó (RN-PB). Mineração e Metalurgia, 80:16-28.

Jardim de Sá E.F., Macedo M.H.F., Torres H.H.F., Kawashita K. 1988. Geochronology of metaplutonics and the evolution of supracrustal belts in the Borborema Province, NE Brazil. Anais do $7^{\circ}$ Congresso Latino-Americano de Geologia, 49-62.

Karhu J., Sial A.N., Ferreira V.P. 2010. Insights from Precambrian Isotope Stratigraphy. Precambrian Research, 182(4):239-412.

Kasemann S.A., Hawkesworth C.J., Prave A.R., Fallick A.E., Pearson P.N. 2005. Boron and Calcium isotope composition in Neoproterozoic carbonate rocks from Namibia: evidence for extreme environmental change. Earth and Planetary Science Letters, 231:73-86.

Kaufman A.J. \& Knoll A.H. 1995. Neoproterozoic variations in the C-isotopic composition of seawater: stratigraphic and biogeochemical implications. Precambrian Research, 73:27-49.

Kaufman A.J., Jacobsen S.B., Knoll A.H. 1993. The Vendian record of $\mathrm{Sr}$ and $\mathrm{C}$ isotopic variations in seawater: implications for tectonics and paleoclimatic. Earth Planetary Science Letters, 120:409-430.
Kaufman A.J., Knoll A.H., Narbonne G.M. 1997. Isotopes, ice ages and terminal Proterozoic earth history. Proceedings of the National Academy of Sciences of the United States of America, 94(13):6600-6605

Kaufman A.J., Sial A.N., Ferreira V.P. 2007. Preface to special issue of Chemical Geology on Precambrian Chemostratigraphy in honor of the late William T. Holser. Chemical Geology, 237:1-4.

Kaufman A.J., Sial A.N., Frimmel H.E., Misi A. 2009. Neoproterozoic to Cambrian Palaeoclimatic events in Southwestern Gondwana. In: Gaucher C., Sial A.N., Halverson G.P., Frimmel H. (eds.). Neoproterozoic-Cambrian Tectonics, Global Change and Evolution: A focus on Southwestern Gondwana. Developments in Precambrian Geology, Amsterdam, Elsevier, 16:369-388.

Kawashita K. 1996. Rochas Carbonáticas Neoproterozóicas da América do Sul: Idades e Inferências Quimioestratigráficas. Tese de Livre-Docência, Instituto de Geociências da Universidade de São Paulo, $126 \mathrm{p}$.

Kawashita K., Varela R., Cingolani C.A., Soliani Jr. E., Linares E., Valencio S.A., Ramos A.V., Do Campo M. 1999. Geochronology and chemostratigraphy of "La Tinta" Neoproterozoic sedimentary rocks, Buenos Aires Province, Argentina. $2^{\text {nd }}$ South American Symposium on Isotope Geology. Actas. Córdoba (Argentina): pp. 403-407.

Kennedy M.J. 1996. Stratigraphy, sedimentology, and isotopic geochemistry of Australian cap dolostones: deglaciation, $\delta^{13} \mathrm{C}$ excursions, and carbonate precipitation. Journal of Sedimentary Research, 66:1050-1064.

Kennedy M.J., Runnegar B., Prave A.R., Hoffmann K. H., Arthur M.A. 1998.Two or four Neoproterozoic glaciations? Geology, 26(12):1059-1063

Knoll A.H., Hayes J.M., Kaufman A.J., Swett K., Lambert I.B. 1986. Secular variation in carbon isotope ratios from Upper Proterozoic successions of Svalbard and East Greenland. Nature, 321:832-838.

Knoll A.H. \& Walter M.R. 1992. Latest Proterozoic stratigraphy and Earth history. Nature, 356:673-678.

Knoll A.H., Kaufman A.J., Semikhatov M.A., 1995. The carbon isotopic composition of Proterozoic carbonates: Riphean successions from northwestern Siberia (Anabar Massif, Turukhansk Uplift). American Journal of Science, 295(7):823-850.

Kuchenbecker M., Babinski M., Pedrosa-Soares A.C., Lopes-Silva L., Pimenta F. 2016. Chemostratigraphy of the lower Bambuí Group, southwestern São Francisco Craton, Brazil: insights on Gondwana paleoenvironments. Brazilian Journal of Geology, 46(Suppl 1):145-162.

Litherland M. \& Bloomfield K. 1981. The proterozoic history of eastern Bolivia. Precambrian Research, 15(2):157-179.

Litherland M., Annels R.N., Appleton J.D., Berrange J.P., Bloomfield K., Burton C.C.J., Darbyshire D.P.F., Fletcher C.J.N., Hawkins M.P., Klink B.A., Llanos A., Mitchel W.I., O'Connors E.A., Pitfield P.E.J., Power G., Werb B.C. 1986. The geology and mineral resources of the Bolivian Precambrian shield. British Geological Survey, Overseas Memoir 9, London, $140 \mathrm{pp}$.

Lyons T.W. \& Reinhard C.T. 2009. Early Earth: Oxygen for heavymetal fans. Nature, 461(7261):179-181.

Maciel, P. 1959. Tilito Cambriano (?) no Estado de Mato Grosso. Boletim da Sociedade Brasileira de Geologia, 81(1):31-39.

Magaritz M., Holser W.T., Kirschvink J.L. 1986. Carbon-isotope events across the Precambrian/Cambrian boundary on the Siberian platform. Nature, 320: 258-259. 
Maheshwari A., Sial A.N., Gaucher C., Bossi J., Bekker A. Ferreira V.P., Romano A.W. 2010. Global nature of the Paleoproterozoic Lomagundi carbon isotope excursion: A review of occurrences in Brazil, India, and Uruguay. In: Karhu, J., Sial, A.N. and Ferreira, V.P. (eds) Precambrian Isotope Stratigraphy. Precambrian Research, 182(4):274-299

Mallmann G., Chemale Jr. F., Avila J.N., Kawashita K., Armstrong R.A. 2007. Isotope geochemistry and geochronology of the Nico Pérez Terrane, Río de la Plata Craton, Uruguay. Gondwana Research, 12(4):489-508

Marimon M.P.C. 1990. Petrologia e litogeoquímica da sequência plutono-vulcanossedimentar do Brejo Seco, Município de São João do Piauí. Dissertação de Mestrado, Instituto de Geociências, Universidade Federal da Bahia, Salvador, 102 pp.

Martins-Neto M.A. \& Alkmim F.F. 2001. Estratigrafia e Evolução Tectônica das Bacias Neoproterozoicas do Paleocontinente São Francisco e suas Margens: Registro de Rodínia e Colagem de Gondwana. In: Pinto, C.P. \& Martins-Neto, M.A. (eds.). Bacia do São Francisco: Geologia e Recursos Naturais. Belo Horizonte (SBG/ $\mathrm{MG)}$, 31-54.

Martins-Neto, M.A., Pedrosa-Soares, A.C. and Lima, S.A.A. 2001. Tectono-sedimentary evolution of sedimentary basin from late Paleoproterozoic to Late Neoproterozoic in the São Francisco craton and Araçuaí fold belt, eastern Brazil. Sedimentary Geology, 141-142:343-370

Masquelin H. C., Sánchez Bettucci L. 1993. Propuesta de evolución tectono-sedimentaria para la Cuenca de Piriápolis, Uruguay. Revista Brasileira de Geociências, 23(3):313-322.

McNamee J. 2001. The Tucavaca trough: potential for sedex type base metal/Ag mineralization in a Late Proterozoic rift in eastern Bolivia” Estilos de mineralizacion en Bolivia, Colegio de Geólogos de Bolivia, La Paz, Bolivia.

Melezhik V.A., Gorokhov I.M., Fallick A.E., Gjelle S. 2001. Strontium and carbon isotope geochemistry applied to dating of carbonate sedimentation: an example from high-grade rocks of the Norwegian Caledonides. Precambrian Research, 108:267-292

Melezhik V.A., Roberts D., Fallick A.E., Gorokhov I.M., Kusnetzov A.B. 2005. Geochemical preservation potential of high-grade calcite marble versus dolomite marble: implication for isotope chemostratigraphy. Chemical Geology, 216:203-224.

Melezhik V.A., Roberts D., Fallick A.E., Gorokhov I.M. 2008. The Shuram-Wonoka event recorded in a high-grade metamorphic terrane: insight from the Scandinavian Caledonides. Geological Magazine, 145(3):161-172.

Misi A. \& Veizer J. 1998. Neoproterozoic carbonate sequences of the Una Group, Irecê Basin, Brazil: chemostratigraphy, age and correlations. Precambrian Research, 89:87-100.

Misi A. \& Kyle J.R. 1994. Upper Proterozoic carbonate stratigraphy, diagenesis and stromatolitic phosphorite formation, Irecê Basin, Bahia, Brazil. Journal of Sedimentary Research, 64:299-310.

Misi A., Iyer S.S.S., Tassinari C.E.S., Kyle C.G.G., Coelho J.R., FrancaRocha W.J.S., Gomes A.S.R., Cunha I.A., Carvalho I.G. 1999b. Geological and isotopic constraints on the metallogenic evolution of the Proterozoic sediment-hosted Pb-Zn (Ag) deposits of Brazil. Gondwana Research, 2(1):47-65.

Misi A., Kaufman A.J., Veizer J., Powis K., Azmy K., Boggiani P.C., Gaucher C., Teixeira J.B.G., Sanches A.L., Iyer S.S.S. 2007. Chemostratigraphic correlation of Neoproterozoic successions in South America. Chemical Geology, 237:143-167.
Misi A., Kaufman A.J., Azmy K., Dardenne M.A., Sial A.N., Oliveira T.F. 2011. Neoproterozoic successions of the São Francisco Craton, Brazil: The Bambuí, Una, Vazante and Vaza Barris/Miaba groups and their glaciogenic deposits. In: Arnaud E., Halverson G. P., Shields-Zhou G. (eds.). The Geological Record of Neoproterozoic Glaciations. Memoir 36, Chapter 48, Geological Society of London, London, 509-522.

Misi A., Azmy K., Kaufman A.J., Oliveira, T.F., Sanches A.L., Oliveira G.D. 2014. Review of the geological and geochronological framework of the Vazante sequence, Minas Gerais, Brazil: Implications to metallogenic and phosphogenic models. Ore Geology Reviews, 63:76-90.

Moraes J.F.S. 1992. Petrologia da sequência vulcano-sedimentar de Monte Orebe, PE/PI. Dissertação de Mestrado, Universidade Federal da Bahia, Salvador, 98 pp.

Narbonne G.M. 2005. The Ediacara Biota: Neoproterozoic origin of animals and their ecosystems. Annual Reviews of Earth Planetary Sciences, 33:421-42.

Nascimento R.S.C., Sial A.N., Pimentel M.M. 2004. Chemostratigraphy of medium-grade marbles of the late Neoproterozoic Seridó Group, Seridó Fold Belt, northeastern Brazil. Gondwana Research, 7:731-744

Nascimento R.S.C., Sial A.N., Pimentel M.M. 2007. C- and Sr-isotope systematics applied to Neoproterozoic marbles of the Seridó belt, northeastern Brazil. Chemical Geology, 237:209-228.

Nogueira A.C.R \& Riccomini C. 2006. O Grupo Araras (Neoproterozoico) na parte norte da Faixa Paraguai e sul do Craton Amazônico, Brazil. Revista Brasileira de Geociências, 36(4):623-640

Nogueira A.C.R., Riccomini C., Sial A.N., Moura C.A.V., Fairchild T.R. 2003. Soft-sediment deformation at the base of the Neoproterozoic Puga cap carbonate (southwestern Amazon Craton, Brazil): confirmation of rapid icehouse to greenhouse transition in snowball Earth. Geology, 31(7):613-616.

Nogueira A.C.R., Riccomini C., Sial A.N., Moura C.A.V., Trindade R.I.F., Fairchild, T.R. 2007. Carbon and strontium isotope fluctuations and paleoceanographic changes in the late Neoproterozoic Araras carbonate platform, southern Amazon craton, Brazil. Chemical Geology, 237:168-190

Och L.M. \& Shields-Zhou G.A. 2012. The Neoproterozoic oxygenation event: environmental perturbations and biogeochemical cycling. Earth-Science Reviews, 110:26-57.

Oliveira E.P., Toteu S.F., Araújo M.J., Cravalho M.J., Nascimento R.S., Bueno J.F., McNaughton N., Basilici G. 2006. Geologic correlation between the Neoproterozoic Sergipano belt (NE Brazil) and the Yaoundé belt (Cameroon, Africa). Journal of African Earth Sciences, 44:470-478

Oliveira, E.P., 2008. Evolução geológica da Faixa Sergipana, limite sul da Provincia Borborema. Workshop sobre a Geologia do Precambriano da Província Borborema. Campinas, Sao Paulo, pp. 14-15.

Oliveira R.G. 1998. Arcabouço geotectônico da região da Faixa Riacho do Pontal, Nordeste do Brasil: dados aeromagnetométricos e gravimétricos. Dissertação de Mestrado, Universidade de São Paulo, São Paulo, 157 pp.

Oyhantçabal P.B., Siegesmund S., Wemmer K., Presnyakov S., Layer P 2009. Geochronological constraints on the evolution of the southern Dom Feliciano Belt (Uruguay). Journal of the Geological Society. 166:1075-1084

Pamoukaghlián K., Poiré D.G., Gaucher C. 2014. Formación Piedras de Afilar. In: Bossi, J., Gaucher, C. (eds.). Geología del Uruguay. Tomo 1: Predevónico, Montevideo, Polo, pp. 121-138. 
Paula-Santos G.M., Babinski M., Kuchenbecker M., Caetano-Filho S., Trindade R.I.F., Pedrosa-Soares A.C. 2015. New evidence of an Ediacaran age for the Bambuí Group in southern São Francisco craton (eastern Brazil) from zircon U-Pb data and isotope chemostratigraphy. Gondwana Research, 28(2):702-720.

Pazos PJ., Sánchez Bettucci L., Tofalo O. 2003. The Record of the Varanger Glaciation at Río de la Plata Craton, Vendian-Cambrian of Uruguay. Gondwana Research, 6(1):65-78.

Pedreira A.J. 1999. Evolução sedimentar e tectônica da Bacia metassedimentar do Rio Pardo: uma síntese. Revista Brasileira de Geociências, 29(3):339-344.

Pedrosa-Soares, A.C., Cordani, U.G., Nutman, A., 2000. Constraining the age of Neoproterozoic glaciation in eastern Brazil: first U-Pb (SHRIMP) data of detrital zircons. Revista Brasileira de Geociências, 30:58-61.

Pimentel M.M., Rodrigues J.B., Emilia S., Della Giustina M., Junges S.L., Matteini M. 2011. The tectonic evolution of the Neoproterozoic Brasília Belt, central Brazil, based on SHRIMP and LA-ICPMS U-Pb sedimentary provenance data: A review. Journal of South American Earth Sciences, 31(4):345-357.

Pinto-Vasquez J. 2001. Yacimientos del tipo Sedex y la Cuenca Tucavaca: Estilos de mineralizacion en Bolivia. Colegio de geólogos de Bolivia, La Paz, Bolivia, pp. 25-30,

Pinho F.E.C., Sial A.N., Figueiredo M.F. 2003. Contribution to the Neoproterozoic $C$ and $O$ isotopic record: carbonate rocks from the Paraguay Belt, Mato Grosso, Brazil. In: IV South American Symposium on Isotope Geology, Salvador, Brasil, Short Papers, 1:386-389.

Poiré D.G. 1987. Mineralogía y sedimentología de la Formación Sierras Bayas en el Núcleo Septentrional de las sierras homónimas, partido de Olavarría, provincia de Buenos Aires. Tese de Doutorado, Facultad de Ciencias Naturales y Museo, Universidad Nacional de La Plata, $271 \mathrm{pp}$.

Poiré D.G. 2014. Grupo Mina Verdún, In: Bossi, J., Gaucher, C. (eds.). Geología del Uruguay. Tomo 1: Predevónico, Montevideo, Polo, pp. 233-251

Poiré D., Gaucher C. 2009. Lithostratigraphy. NeoproterozoicCambrian evolution of the Río de la Plata Palaeocontinent, In: Gaucher C., Sial A.N., Halverson G.P., Frimmel H.E. (eds.). Neoproterozoic-Cambrian tectonics, global change and evolution: a focus on southwest Gondwana. Developments in Precambrian Geology, Amsterdam, Elsevier, 16:87-101.

Ramacciotti C.D., Baldo E.G., Casquet C. 2015. U-Pb SHRIMP detrital zircon ages from the Neoproterozoic Difunta Correa Metasedimentary Sequence (Western Sierras Pampeanas, Argentina): Provenance and paleogeographic implications. Precambrian Research, 270:39-49.

Rapalini A.E., Trindade R.I., Poiré D.G. 2013. The La Tinta pole revisited: Paleomagnetism of the Neoproterozoic Sierras Bayas Group (Argentina) and its implications for Gondwana and Rodinia. Precambrian Research, 224:51-70.

Rapalini A.E., Tohver E., Sánchez Bettucci L., Lossada A.C., Barcelona H., Pérez C. 2015. The late Neoproterozoic Sierra de las Ánimas Magmatic Complex and Playa Hermosa Formation, southern Uruguay, revisited: Paleogeographic implications of new paleomagnetic and precise geochronologic data. Precambrian Research, 259:143-155.

Riccomini C., Nogueira A.C.R., Sial A.N. 2007. Carbon and oxygen isotope geochemistry of Ediacaran outer platform carbonates, Paraguay Belt, central Brazil. Anais da Academia Brasileira de Ciências, 79(3):519-527.
Ries J.B., Fike D.A., Pratt L.M., Lyons T.W., Grotzinger J.P. 2009. Superheavy pyrite $\left(\delta^{34}\right.$ Spyr $\left.>\delta{ }^{34} S_{C A S}\right)$ in the terminal Proterozoic Nama Group, southern Namibia: A consequence of low seawater sulfate at the dawn of animal life. Geology, 37(8):743-746.

Ripperdan R.L., Magaritz M., Nicoll R.S., Shergold J.H. 1992. Simultaneous changes in carbon, sea level, and conodont biozones within Cambrian-Ordovician boundary interval at Black Mountain, Australia. Geology, 20(11):1039-1042.

Santana A.V.A., Chemale Jr. F., Scherer C., Guadagnin F. and Pereira C.P. 2016. New insights of carbonate sedimentation of the Irecê Basin, São Francisco Craton, based on stratigraphic analyses and isotope studies (submitted).

Santos R.A. \& Souza, J.D. 1988. Programa Levantamentos Geológicos Básicos do Brasil; carta metalogenética/previsional, escala 1:100.000 (Folha SC.24-X-C-VI Piranhas). DNPM/CPRM, 154 p.

Santos R.V., Alvarenga C.J.S., Dardenne M.A., Sial A.N., Ferreira V.P. 2000. Carbon and oxygen isotopes across Meso-Neoproterozoic limestones from Central Brazil: Bambui and Paranoá Groups. Precambrian Research, 104:107-122.

Santos R.A., Martins A.A.M., Neves J.P., Leal R.A. 1998. Geologia e Recursos Minerais do Estado de Sergipe. Companhia de Pesquisa de Recursos Minerais de Sergipe.

Santos R.V., Alvarenga C.J.S., Babisnki M., Ramos, M.L.S., Cukrov N., Fonseca M.A., Sial N.A., Dardenne M.A., Noce C.M. 2004. Carbon isotopes of Mesoproterozoic-Neoproterozoic sequences from Southern São Francisco craton and Araçuaí Belt, Brazil: Paleographic implications. Journal of South American Earth Sciences, 18:27-39.

Santos R.V., Oliveira, C.G.D., Parente C.V., Garcia M.D.G.M., Dantas E.L. 2013. Hydrothermal alteration related to a deep mantle source controlled by a Cambrian intracontinental strike-slip fault: Evidence for the Meruoca felsic intrusion associated with the Transbrasiliano Lineament, northeastern Brazil. Journal of South American Earth Sciences, 43:33-41.

Santos S.T.J., Fetter A.H., Hackspacher P.C., Van Schmus W.R., Nogueira Neto J.A. 2008. Neoproterozoic tectonic and magmatic episodes in the NW sector of Borborema Province, NE Brazil, during assembly of Western Gondwana. Journal of South American Earth Sciences, 25(3):271-284.

Schidlowski M., Hayes J.M., Kaplan I.R., 1983. Isotopic inferences of ancient biochemistries: carbon, hydrogen and nitrogen. In: Schopf, J.W. (ed.). Earth's Earliest Biosphere: Its Origin and Evolution. Princeton University Press, Princeton, pp. 149-186.

Schoenberg R., Zink S., Staubwasser M., Von Blanckenburg F. 2008. The stable $\mathrm{Cr}$ isotope inventory of solid Earth reservoirs determined by double spike MC-ICP-MS. Chemical Geology, 249:294-306.

Shields-Zhou G. \& Och, L. 2011. The case for a Neoproterozoic Oxygenation Event: geochemical evidence and biological consequences. GSA Today, 21(3):4-11.

Shields-Zhou G., Porter S, Halverson GP 2016. A new rockbased definition for the Cryogenian Period (circa 720-635 Ma). Episodes, 39:1-8.

Sial A.N. 1989. Petrologia, geoquímica de elementos maiores, traços, terras raras e isótopos ( $\mathrm{Sr}, \mathrm{O}, \mathrm{H}, \mathrm{S})$ nos batólitos da Meruoca e Mocambo, Ceará, Nordeste do Brasil. Tese de Titular, Universidade Federal de Pernambuco, Recife, $284 \mathrm{p}$.

Sial A.N. \& Long L.E. 1987. Mineral chemistry and stable isotope geochemistry of the Cambrian Meruoca and Mucambo plutons, Ceará, Northeast Brazil. In: International Symposium on Granites and Associated Mineralizations (ISGAM), Salvador, Brazil, 185-188. 
Sial A.N., Karhu J., Ferreira V.P. 2010a. Insights from Isotope Stratigraphy. Preface to the Special Issue on Precambrian Isotope Stratigraphy. Precambrian Research, 182(4): v-viii.

Sial AN, Ferreira VP, Mariano G, Chaves NS e Almeida J da C, 1992. Isótopos de carbono e oxigênio em calcareos Gramame e Maria Farinha, Pernambuco: uma contribuição ao estudo da transição Cretaceo-Terciario. $37^{\circ}$ Congresso Brasieiro de Geologia, São Paulo (extended Abstract), pp. 465-467.

Sial A.N., Ferreira V.P., Almeida A.R., Moura C.V.A. 2003. C-, O- and Sr isotope composition and age of the carbonates of the Frecheirinha Formation, NW Ceará, Northeastern Brazil. IX Congresso Brasileiro de Geoquímica. Belém, Pará. Resumos Expandidos, 410-411.

Sial A.N., Ferreira V.P., Almeida A.R., Romano A.W., Parente C.V., Costa M.L., Santos V.H. 2000. Carbon isotope fluctuations in Precambrian carbonate sequences of several localities in Brazil. Anais Academia Brasileira de Ciências 72: 539-558.

Sial A.N., Ferreira V.P., Silva Filho M.A., Gaucher C., Soares D.R. Silva Filho E.V., Pimentel M.M., Lacerda L.D., Gantois G. 2006. Chemostratigraphy of two Neoproterozoic cap carbonates of the Sergipano belt (northeastern Brazil). Short Papers, V South American Symposium on Isotope Geology, Punta del Este, Uruguay, 314-317.

Sial A.N., Peralta S., Ferreira V.P., Toselli A.J., Aceñolaza F.G., Parada M.A., Gaucher C., Alonso R.N., Pimentel M.M. 2008. Upper Cambrian carbonate sequences of the Argentine Precordillera and the Steptoean C-isotope positive excursion (SPICE). Gondwana Research 13: 437-452

Sial A.N., Dardenne M.A., Misi A., Pedreira A.J., Gaucher C., Ferreira V.P. Silva Filho M.A. Uhlein A., Pedrosa-Soares A.C. Santos R.V. Egydio-Silva M., Babinski M., Alvarenga C.J., Fairchild T.R., Pimentel M.M. 2009. The São Francisco Paleocontinent. In: C. Gaucher A.N., Sial, G.P., Halverson and H. Frimmel (eds). In: Gaucher C., Sial A.N., Halverson G.P., Frimmel H.E. (eds.). Neoproterozoic-Cambrian tectonics, global change and evolution: a focus on southwest Gondwana. Developments in Precambrian Geology, Amsterdam, Elsevier, 16: 31-69.

Sial A.N., Gaucher C., Silva Filho M.A., Ferreira V.P., Pimentel M.M., Lacerda L.D., Silva Filho E.V., Cezario W. 2010b. C-, Sr-isotope and $\mathrm{Hg}$ chemostratigraphy of Neoproterozoic cap carbonates of the Sergipano Belt, Northeastern Brazil. In: Karhu J., Sial A.N., Ferreira V.P., Eds, Precambrian Isotope Stratigraphy, special issue, Precambrian Research 182: 351-372.

Sial A.N., Campos M.S., Gaucher C., Frei R., Ferreira V.P., Nascimento R.C., Pimentel M.M., Pereira N.S., Rodler A. 2015a. Algoma-type Neoproterozoic BIFs and related marbles in the Seridó Belt (NE Brazil): REE, C, O, Cr and Sr isotope evidence. Journal of South American Earth Sciences 61, 33-52.

Sial A.N., Gaucher, G., Ferreira V.P., Pereira N.S., Cezario W.S., Chiglino L., Monteiro H. 2015b. Isotope and Elemental Chemostratigraphy. M. Ramkumar (editor): Chemostratigraphy, Concepts, Techniques and Applications, Elsevier, 23-64.

Silva Filho M.A. \& Brito Neves B.B. 1979. O sistema de dobramentos Sergipano no Nordeste da Bahia. Geologia Recursos Minerais do Estado da Bahia, Textos Básicos 1: 203-217.

Silva Filho M.A., Torres H.H.F. 2002. A new interpretation on the Sergipano belt Domain.Anais da Academia Brasileira de Ciencias 74: 556-557.

Silva Filho A.F., Acioly A.C.A., Torres H.H.F., Araújo, R.V. 2003. O complexo Jaramataia no contexto do Sistema Sergipano. Revista de Geologia 16: 99-110

Silva-Tamayo J.C., Nägler T., Villa I.M., Kyser K., Vieira L.C., Sial A.N., Narbonne G.M., James N.P. 2010a. Global Ca isotope variations in Post-Sturtian carbonate successions. Terra Nova 22: 188-194.
Silva-Tamayo J.C., Nägler T.F., Nogueira A., Kyser, K., Villa, Igor Riccomini, C., Sial A.N., Narbonne G.M., and James N.P. 2010b. Global Ca isotope variations in c. $0.7 \mathrm{Ga}$ old post-glacial carbonate successions. In: Karhu J., Sial A.N., Ferreira V.P., Eds, Precambrian Isotope Stratigraphy, special issue, Precambrian Research 182: 373-381.

Souza J.O., Santos D.R.V., Silva M.F., Frasca A.A.S., Borges, F.R., Gollmann K. 2012. Projeto Planalto da Serra, Estado de Mato Grosso, Programa Geologia do Brasil, CPRM, Goiânia, 105pp.

Souza, S. C. R. 2015. Detalhamento Estratigráfico das Unidades superiores do Neoproterozóico da Faixa Paraguai. MSc thesis, Instituto de Geociências, Universidade de Brasília, Brazil.

Spangenberg J.E., Bagnoud-Velasquez M., Boggiani P.C., Gaucher C. 2014. Redox variations and bioproductivity in the Ediacaran: Evidence from inorganic and organic geochemistry of the Corumbá Group, Brazil. Gondwana Research 26: 1186-1207.

Sprechmann P., Gaucher C., Blanco G., Montaña, J. 2004. Stromatolitic and trace fossils community of the Cerro Victoria Formation, Arroyo del Soldado Group (lowermost Cambrian, Uruguay). Gondwana Research 7: 753-766.

Torquato JRF \& Misi A 1977. Medidas isotópicas de carbono e oxigênio em carbonatos do Grupo Bambuí na região centro-norte do Estado da Bahia. Revista Brasileira de Geociências 7: 14-24.

Torquato JRF 1980. Aplicações dos Isótopos Estáveis de Carbono e Oxigênio ao Estudo do Precambriano Brasileiro. Tese apresentada ao concurso de Professor Titular, Departamento de Geociências da Universidade Federal do Ceará, 277 pp.

Toselli A.J., Aceñolaza G.F., Miller H., Adams C., Aceñolaza F.G., Rossi J.N. 2012. Basin evolution of the margin of Gondwana at the Neoproterozoic/Cambrian transition: the Puncoviscana Formation of Northwest Argentina. - Neues Jahrbuch Geologie und Paläontologie, Abhandlungen 265: 79-95.

Trompette R. 1994. Geology of Western Gondwana (2000-500 Ma). A.A. Balkema, Rotterdam, 350 p.

Trompette R., Alvarenga C.J.S. de, Walde D. 1998. Geological evolution of the Neoproterozoic Corumbá graben system (Brazil). Depositional context of the stratified Fe and Mn ores of the Jacadigo Group. Journal of South American Earth Sciences 11: 587-597.

Van Schmus W.R., Dantas E.L., Brito Neves B.B., Hackspacher P.C., Babinski M. 1996. Neoproterozoic age for Seridó Group, NE Borborema Province, Brazil. In: Anais 39 Congresso Brasileiro Geologia, v. 6: 152-155.

Van Schmus W.R., Brito Neves B.B., Williams I.S., Hackspacher P.C., Fetter A.H., Dantas E.L., Babinski M. 2003. The Seridó Group of NE Brazil, a late Neoproterozoic pre- to syn-collisional basin in West Gondwana: insights from SHRIMP U-Pb detrital zircon ages and Sm-Nd crustal residence (TDM) ages. Precambrian Research 127: 287-327.

Veizer J., Holser W.T., Wilgus C.K. 1980. Correlation of ${ }^{13} \mathrm{C} /{ }^{12} \mathrm{C}$ and ${ }^{34} \mathrm{~S} /{ }^{32} \mathrm{~S}$ secular variations. Geochimica Cosmochimica Acta 44: 579-588.

Veizer J., Ala D., Azmy K., Bruchschen P., Buhl D., Bruhn F., Giles A.F., Diener A., Ebneth S., Godderis Y., Jasper T., Korte C., Pawallek F., Podlaha O.G., Strauss H., $1999 .{ }^{87} \mathrm{Sr} /{ }^{86} \mathrm{Sr}, \delta^{13} \mathrm{C}$ and $\delta^{18} \mathrm{O}$ evolution of Phanerozoic seawater. Chemical Geology 161: 59-88.

Walde D. H. G., Hagemann S. 2007. The Urucum/Mutum Fe and Mn deposits in W-Brazil/Bolivia: assessment of genetic model. Deutsche Gesellschaft fuer Geowissenschaften. Zeitschrift 158: 45-55.

Warren L.V., Boggiani P.C., Campanha G.A.C., Gaucher G., Poiré D., Inchausti C.G., Sial A.N. 2010. Stratigraphic correlation between Corumbá (BR) and Itapucumi (PY) groups. $18^{\text {th }}$ International Sedimentological Congress, Mendoza, Argentina, p. 913. 
Warren L.V. 2011. Tectônica e sedimentação do Grupo Itapucumi (Neoproterozóico, Paraguai Setentrional. Doctoral Thesis, Institute of Geosciences, University of São Paulo, São Paulo, $215 \mathrm{p}$.

Warren L.V., Fairchild T.R., Gaucher C., Boggiani P.C., Poiré D.G., Anelli L.E., Inchausti J.C.G. 2011.Corumbella and in situ Cloudina in association with thrombolites in the Ediacaran Itapucumi Group, Paraguay: Terra Nova 23: 382-389.

Warren L.V., Pacheco M.L.A.F., Fairchild T.R., Simões M.G., Riccomini C., Boggiani P.C., Cáceres, A.A. 2012. The dawn of animal skeletogenesis: Ultrastructural analysis of the Ediacaran metazoan Corumbella werneri. Geology 40: 691-694.
Warren L.V., Quaglio F., Riccomini C., Simões M.G., Poiré D.G., Strikis N.M. Anelli L.E., Strikis P.C. 2014. The puzzle assembled: Ediacaran guide fossil Cloudina reveals an old proto-Gondwana seaway. Geology 42: 391-394.

Zaine, M.F. 1991. Análise dos fósseis de parte da Faixa Paraguai (MS, MT) e seu contexto temporal e paleoambiental. Tese de doutorado, Universidade de São Paulo, 218 p.

Zhao Y., Zheng, Y., Chen F. 2009. Trace element and strontium isotope constraints on sedimentary environment of Ediacaran carbonates in southern Anhui, South China. Chemical Geology 265: 345-362.

Available at www.sbgeo.org.br 